\title{
PURIFICAÇÃO DE SUBUNIDADES DO VÍRUS DA RAIVA POR MEIO DE CROMATOGRAFIA
}

\begin{abstract}
Tese apresentada ao Programa de Pós-Graduação Interunidades em Biotecnologia USP/Instituto Butantan/ IPT, para obtenção do Título de Doutor em Biotecnologia.
\end{abstract}


GRACIANE MARIA MEDEIROS CAPORALE

\section{PURIFICAÇÃO DE SUBUNIDADES DO VÍRUS DA RAIVA POR MEIO DE CROMATOGRAFIA}

Tese apresentada ao Programa de Pós-Graduação Interunidades em Biotecnologia USP/ Instituto Butantan/ IPT, para obtenção do Título de Doutor em Biotecnologia.

Área de Concentração: Biotecnologia

Orientador: Dr. Patrick Jack Spencer 
DADOS DE CATALOGAÇÃO NA PUBLICAÇÃO (CIP)

Serviço de Biblioteca e Informação Biomédica do

Instituto de Ciências Biomédicas da Universidade de São Paulo

(C) reprodução total

Caporale, Graciane Maria Medeiros.

Purificação de subunidades do vírus da raiva por meio de cromatografia / Graciane Maria Medeiros Caporale. -- São Paulo, 2010.

Orientador: Patrick Jack Spencer.

Tese (Doutorado) - Universidade de São Paulo. Instituto de Ciências Biomédicas. Programa de Pós-Graduação Interunidades em Biotecnologia USP/IPT/Instituto Butantan. Área de concentração: Biotecnologia. Linha de pesquisa: Imunologia, virologia, raiva.

Versão do título para o inglês: Purification of subunits of the rabies virus by chromatography.

Descritores: 1. Vírus da raiva 2. Ribonucleoproteína 3. Purificação 4. Cromatografia 5. Imunoatividade 6. Diagnóstico I. Spencer, Patrick Jack II. Universidade de São Paulo. Instituto de Ciências Biomédicas. Programa de Pós-Graduação Interunidades em Biotecnologia USP/IPT/Instituto Butantan III. Título. 
UNIVERSIDADE DE SÃO PAULO

Programa de Pós-Graduação Interunidades em Biotecnologia

Universidade de São Paulo, Instituto Butantan, Instituto de Pesquisas Tecnológicas

Candidato(a): $\quad$ Graciane Maria Medeiros Caporale.

Título da Tese: $\quad$ Purificação de subunidades do vírus da raiva por meio de cromatografia .

Orientador(a): $\quad$ Patrick Jack Spencer.

A Comissão Julgadora dos trabalhos de Defesa da Tese de Doutorado, em sessão pública realizada a .$/ . . . . . . . . . . . . . .$, considerou

\section{( ) Aprovado(a) ( ) Reprovado(a)}

\begin{tabular}{|c|c|}
\hline Examinador(a): & $\begin{array}{l}\text { Assinatura: } \\
\text { Nome: ....... } \\
\text { Instituição: }\end{array}$ \\
\hline Examinador(a): & $\begin{array}{l}\text { Assinatura: } \\
\text { Nome: ....... } \\
\text { Instituição: }\end{array}$ \\
\hline Examinador(a): & $\begin{array}{l}\text { Assinatura: } \\
\text { Nome: ....... } \\
\text { Instituição: }\end{array}$ \\
\hline Examinador(a): & $\begin{array}{l}\text { Assinatura: } \\
\text { Nome: ....... } \\
\text { Instituição: }\end{array}$ \\
\hline Presidente: & $\begin{array}{l}\text { Assinatura: } \\
\text { Nome: ....... } \\
\text { Instituição: }\end{array}$ \\
\hline
\end{tabular}




\section{Certificado}

Certificamos que o protocolo registrado sob $n^{\circ} 051$ nas fls. 45 do livro 2 para uso de animais em experimentação, sob a responsabilidade de Patrick Jack Spencer Coordenador(a) da Linha de pesquisa "Purificação de subunidades do virus da raiva por meio de cromatografia" do qual participou(aram) o(s) Os pesquisadores Ruth Camargo Vassão, Graciene Maria Medieros Caporale, está de acordo com os Princípios Éticos de Experimentação Animal adotado pelo Colégio Brasileiro de Experimentação Animal (COBEA) e foi aprovado pela COMISSÃO DE ÉTICA EM EXPERIMENTAÇÃO ANIMAL (CEEA) em 22.10.2007.

São Paulo, 23 de outubro de 2007.

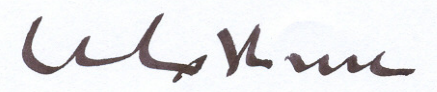

Prof. Dr. Wothan TAVARES DE LIMA Coordenador CEEA - ICB/USP

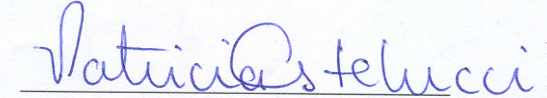

Profa. Dra. PATRÍCIA CASTELUCCI Secretária CEEA - ICB/USP 
Aos meus pais, Emilia Medeiros Caporale e Benedicto Antônio Caporale, pela maravilhosa oportunidade que deram a essa filha de viver e seguir aprendendo.

Aos meus queridos irmãos Silvio, Silvana e Flávio - Obrigada por nosso amor, pela confiança e apoio que temos uns pelos outros Admiro muito vocês!

Aos meus sobrinhos Camila, Gabriel e Richard - vocês são lindas flores do jardim dessa família. 
À minha querida irmã Silvia Maria Medeiros Caporale que sempre me deu força e apoio nesses caminhos de estudante - você passará por este momento de maneira brilhante! 


\section{AGRADECIMENTOS}

Ao Dr. Patrick Jack Spencer pela orientação e ensinamentos para a execução deste trabalho;

À Dra. Ruth Camargo pela coorientação e apoio;

Às grandes companheiras de equipe Andréa de Cássia Rodrigues da Silva, Luciana Botelho Chaves e Karin Corrêa Scheffer Ferreira, vocês fazem parte de cada linha deste trabalho - Acho que temos vivido a graça de aprender nesses tempos sobre o que é a real - Atitude Solidariedade!;

À Dra. Zélia Maria Pinheiro Peixoto, pelo incentivo e apoio de tantos projetos em minha vida;

Ao Elpidio Ferreira pela amizade e tantas colaborações;

À Ana Elena Boamorte da Costa pela amizade, colaboração e companheirismo;

Ao querido Alexandre Mendes Batista pela amizade, colaboração e paciência de tantas idas e vindas em nossos protocolos!

À Paula Sônia Cruz, Samira Maria Achkar Pinheiro (Nenê), Geralda R. Fraga, Karina Ribeiro e Maria Aparecida da Silva - pessoas com as quais sempre pude contar; Ao Dr. Pedro Carnieli Junior pela amizade e apoio, sempre que precisei;

Aos amigos do Instituto de Pesquisas Energéticas e Nucleares (IPEN) Rodrigo G. Queiroz, Karina C. Oliveira, Tamara M. Fucase e Rosa Maria Chura-Chambi pela grande disposição em ajudar em tantos momentos;

À querida Susana Rosalba Lourenço, por todos esses anos de confiança, amizade e palavras que me incentivam sempre;

Aos amigos do laboratório do Instituto Pasteur pelo companheirismo do dia-a-dia; Ao Instituto Pasteur pela oportunidade de 17 anos de aprimoramento profissional; À Direção do Instituto Pasteur por viabilizar e apoiar este estudo.

Muito obrigada! 


\section{RESUMO}

Caporale GMM. Purificação de subunidades do vírus da raiva por meio de cromatografia [tese (Doutorado em Biotecnologia)]. São Paulo (Brasil): Instituto de Ciências Biomédicas Universidade de São Paulo; 2010.

As subunidades do vírus da raiva podem ser purificadas por meio de diferentes metodologias e podem ter diversas aplicações para o diagnóstico laboratorial e pesquisa da Raiva. O método de ultracentrifugação em gradiente de Cloreto de Césio ( $\mathrm{CsCl}$ ) possibilita a obtenção de concentrações semi purificadas de ribonucleoproteínas (RNP) do vírus da raiva. Outro método muito usado para a purificação de proteínas é a cromatografia, a qual vem sendo empregada na purificação do vírus da raiva, cultivado em células, para produção de vacinas. 0 objetivo deste estudo foi estabelecer metodologia de purificação de RNP por meio de cromatografia de imunoafinidade, para aumentar o grau de pureza das proteínas e reduzir o tempo operacional do processo. Após seleção entre as cepas virais, PV (Pasteur Virus) e CVS (Challenge Virus Standard) realizada em células BHK-21 (Baby Hamster Kidney), foram preparados lotes destas células infectadas com CVS, cepa selecionada por ter apresentado intensidade de fluorescência superior a cepa PV, mantidas por 48 horas em sistema estático ou roller, para a extração das RNP, a partir da lise celular. A concentração e semipurificação das RNP foi realizada por meio de ultracentrifugação em gradiente de $\mathrm{CsCl}$, para a imunização de coelhos e obtenção de soros hiperimunes, dos quais foram purificados os anticorpos por meio de cromatografia de troca iônica e afinidade (proteína A). As imunoglobulinas (lg) purificadas foram então acopladas à sepharose 4B ativada com brometo de cianogênio, a qual foi empacotada e utilizada para purificação das RNP, pela passagem de amostras de lisado celular na coluna de imunoafinidade, em ciclos sob fluxo de $1 \mathrm{~mL} / \mathrm{minuto}$ em sistema Äkta Purifier. Após lise das células cultivadas em sistema estático e roller foram obtidos $15 \mathrm{~mL}$ e $100 \mathrm{~mL}$ de solução proteíca, respectivamente, sendo que ambas soluções de RNP, após ultracentrifugação, apresentaram concentrações protéicas satisfatórias para a imunização dos animais. O soro hiperimune com maior título de anticorpos anti RNP (1:2600), quando purificado por cromatografia de afinidade, possibilitou a obtenção das IgG com elevado grau de pureza e concentração protéica de 3,6 mg/mL, em 19,0 mL. Houve eficiência de $78 \%$ na reação de acoplamento dos anticorpos ao gel de sepharose 4B, permitindo o empacotamento de coluna de 0,9 mL. As amostras de lisado celular contendo RNP, submetidas à purificação na coluna de imunoafinidade, resultaram em frações com concentração protéica de RNP de 0,096 mg/mL para o primeiro ciclo e $0,275 \mathrm{mg} / \mathrm{mL}$ para o segundo ciclo e com a banda correspondente à massa molecular da nucleoproteína (57 kDa) observada na eletroforese. A metodologia de cromatografia de imunoafinidade foi estabelecida com sucesso e propiciou, com baixo tempo operacional, a obtenção de RNP com elevado grau de pureza.

Palavras-chave: Vírus da raiva. Ribonucleoproteínas. Purificação. Cromatografia. Imunoafinidade. 


\begin{abstract}
Caporale GMM. Purification of subunits of rabies virus by chromatography [ Ph.D. in Biotechnology]. São Paulo (Brazil): Instituto de Ciências Biomédicas da Universidade de São Paulo; 2010.
\end{abstract}

The subunits of the rabies virus can be purified by different methodologies and may have several applications for both laboratorial diagnosis and research of rabies disease. The method of ultracentrifugation in cesium chloride $(\mathrm{CsCl})$ gradient enables the achievement of concentrations semi purified ribonucleoprotein (RNP) of rabies virus. Another widely used technique for protein purification is chromatography, which has been used in the purification of rabies virus grown in cells, for vaccine production. The aim of this study was to establish methodology for purification of RNP by immunoaffinity chromatography, to increase the purity of the protein and reduce the operating time of the process. After selection among viral strains, PV (Pasteur Virus) and CVS (Challenge Virus Standard) held in BHK-21 cells (Baby Hamster Kidney), were prepared batches of these cells infected with CVS strain selected for having presented fluorescence intensity than PV strain, maintained for 48 hours in static or roller system for extraction of RNP from the cell lysis. The concentration and semi purification of RNP were performed by ultracentrifugation in $\mathrm{CsCl}$ gradient, to immunize rabbits and obtain hyperimmune sera, of which the antibodies were purified by ion exchange chromatography and affinity (protein $A$ ). Immunoglobulins ( $\mathrm{lg}$ ) were purified then coupled to Sepharose 4B activated with cyanogen bromide, which was packaged and used for purification of the RNP, by passing the cell lysate samples on immunoaffinity column, in cycles in a flow of 1 $\mathrm{mL} / \mathrm{min}$ in Äkta Purifier system. After cells lysis of grown in static system and roller were obtained $15 \mathrm{~mL}$ and $100 \mathrm{~mL}$ of protein solution, respectively, and both RNP solutions, after ultracentrifugation, showed satisfactory concentrations of protein for animal immunization. The hyperimmune serum with highest titer of antibodies anti RNP (1:2600), when purified by affinity chromatography, allowed the obtainment of IgG with high purity and protein concentration of $3.6 \mathrm{mg} / \mathrm{mL}, 19.0 \mathrm{~mL}$. The efficacy was of $78 \%$ in the coupling reaction of antibodies to Sepharose $4 \mathrm{~B}$ gel, allowing the packing column of $0.9 \mathrm{~mL}$. Samples of cell lysate containing RNP, subjected to purification on immunoaffinity column, resulted in fractions of RNP with protein concentration of $0.096 \mathrm{mg} / \mathrm{mL}$ for the first cycle and $0.275 \mathrm{mg} / \mathrm{mL}$ for the second cycle and in electrophoresis was observed the band corresponding to molecular mass of nucleoprotein $(57 \mathrm{kDa})$. The methodology of immunoaffinity chromatography has been successfully established and provided obtaining of RNP with high purity and reduction of operating time.

Keywords: Rabies virus. Ribonucleoproteins. Purification. Chromatography. Immunoaffinity. 


\section{LISTA DE ABREVIATURAS}

$\begin{array}{ll}\text { AA } & \text { Aminoácidos } \\ \text { AcN } & \text { Anticorpos Neutralizantes } \\ \text { ATCC } & \text { American Type Cell Culture } \\ \text { BHK-21 } & \text { Baby hamster kidney - 21- células de rim de hamster recém nascido } \\ \text { CVS } & \text { Challenge Virus Standard - Vírus de desafio padrão } \\ \text { DC } & \text { Domínio citoplasmático da G } \\ \text { DICC100 } & \text { Dose Infectante em Cultura Celular 100\% } \\ \text { DO } & \text { Densidade Ótica } \\ \text { ED } & \text { Ectodomínio da proteína G } \\ \text { G } & \text { Glicoproteína do vírus da raiva } \\ \text { ICTV } & \text { International Committee on Taxonomy of Viruses } \\ \text { IFD } & \text { Imunofluorescência direta } \\ \text { IFI } & \text { Imunofluorescência indireta } \\ \text { IP/SP } & \text { Instituto Pasteur - São Paulo } \\ \text { ITCF } & \text { Isotiocianato de Fluoresceína } \\ \text { KIU } & \text { Kallicrein inactivators units } \\ \text { L } & \text { RNA polimerase do vírus da raiva } \\ \text { M } & \text { Proteína de matriz } \\ \text { MEM } & \text { Meio essencial mínimo de Eagle } \\ \text { MM } & \text { Massa molecular } \\ \text { N } & \text { Nucleoproteína do vírus da raiva } \\ \text { NT } & \text { Nucleotídeo } \\ \text { OMS } & \text { Organização Mundial da Saúde } \\ \text { P } & \text { Fosfoproteína do vírus da raiva } \\ \text { OS } & \text { Domínio peptídeo sinal da G } \\ \text { PV } & \text { Pasteur Vírus } \\ \text { RNA } & \text { Ácido ribonucléico } \\ \text { RNP } & \text { Ribonucleoproteínas } \\ \text { SDS-PAGE } & \text { Eletroforese em gel de poliacrilamida-sódio dodecilsulfato } \\ \text { SFB } & \text { Soro fetal bovino } \\ \text { SFIMT } & \text { Simplified Fluorescence Inhibition Microtest - Microteste simplificado de } \\ & \text { inibição de focos fluorescentes } \\ \text { SNC } & \text { Sistema nervoso central } \\ \text { TM } & \text { Domínio transmembrana da G } \\ & \end{array}$




\section{LISTA DE FIGURAS}

Figura 1. Casos de raiva humana diagnosticados no Brasil no período de 1980 a 2010*.

Figura 2. Micrografia eletrônica de ribonucleoproteínas (RNP) do vírus da raiva.

Figura 3. Representação esquemática do vírus da raiva.

Figura 4. Representação simplificada do ciclo de replicação do vírus da raiva.

Figura 5. Fluxograma das etapas realizadas no desenvolvimento deste estudo.

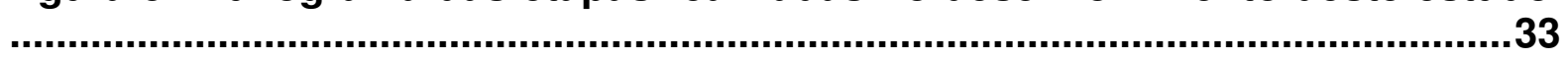

Figura 6. Etapas de replicação e purificação de RNP em sistema estático. ......36

Figura 7. Replicação do vírus da raiva em sistema roller.................................37

Figura 8. Coluna de imunoafinidade antiRNP - matriz CNBr- activated

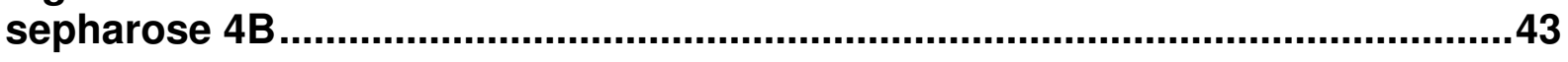

Figura 9. Cromatografia em sistema ÄKTA Purifier - obtenção de RNP ...........44

Figura 10. IFD em células BHK-21 infectadas com a cepa PV............................45

Figura 11. IFD em células BHK-21 infectadas com a cepa CVS.........................45

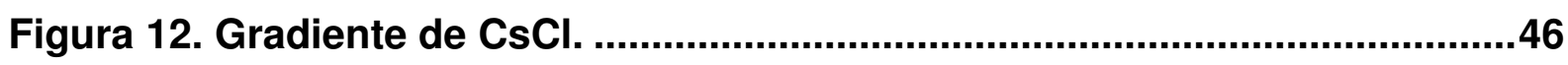

Figura 13. Eletroforese em gel de poliacrilamida (SDS-Page)...........................47

Figura 14. Imunofluorescência indireta, soro anti RNP do coelho A...................48

Figura 15. Imunofluorescência indireta, soro anti RNP do coelho B..................48

Figura 16. Perfil cromatográfico da purificação das imunoglobulinas (IgG) em coluna de afinidade Hi Trap rProtein A FF......................................................49

Figura 17. Eletroforese em gel de poliacrilamida (SDS-Page)...........................50

Figura 18. Perfil cromatográfico da purificação das RNP a partir da obtenção inicial por ultracentrifugação em gradiente de $\mathrm{CsCl}$............................................51

Figura 19. Perfil cromatográfico da purificação das RNP a partir de lisado

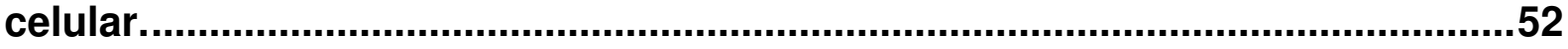

Figura 20. Perfil cromatográfico da purificação das RNP a partir de lisado

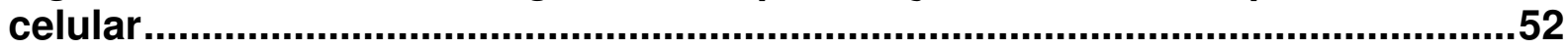

Figura 21. Amostra de RNP- lisado celular $0,5 \mathrm{~mL}$...........................................53

Figura 22. Amostra de RNP- lisado celular $4 \mathrm{~mL}$...............................................54 


\section{SUMÁRIO}

1 INTRODUÇÃO

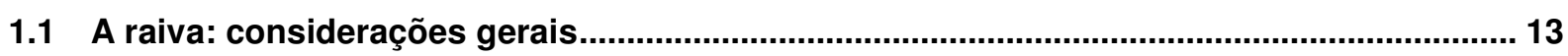

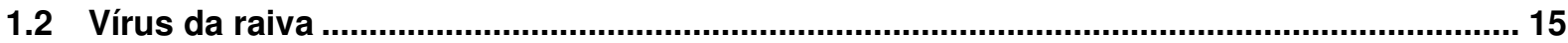

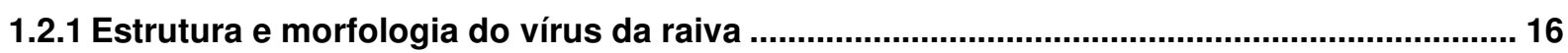

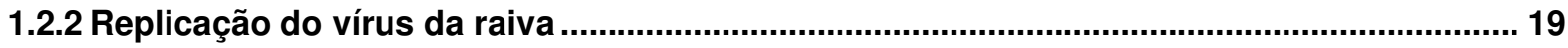

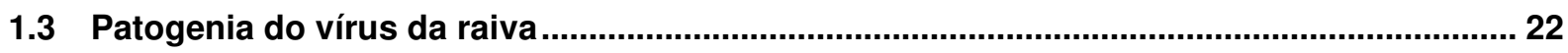

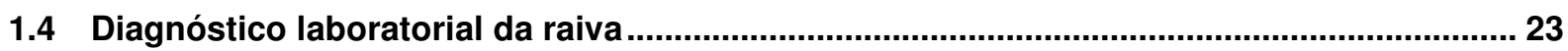

1.4.1 Detecção do vírus da raiva por imunofluorescência direta ................................................... 25

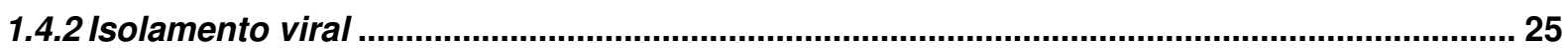

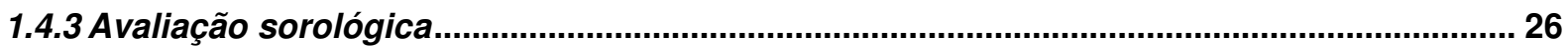

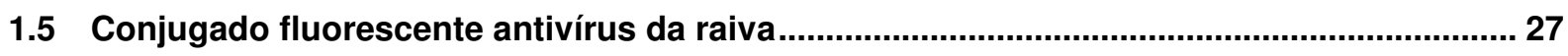

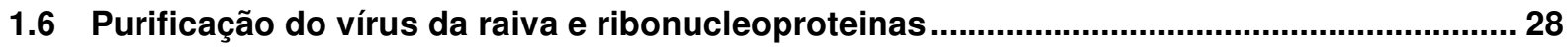

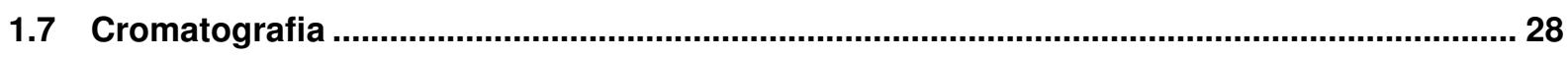

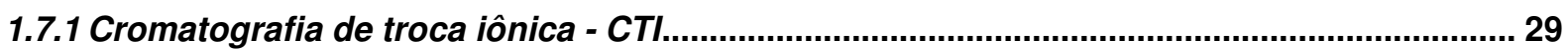

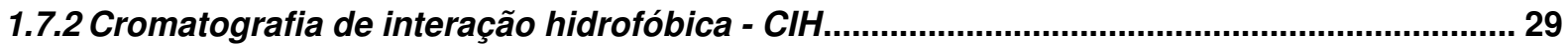

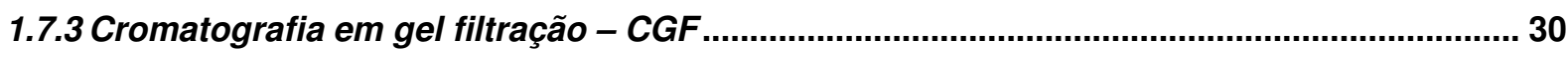

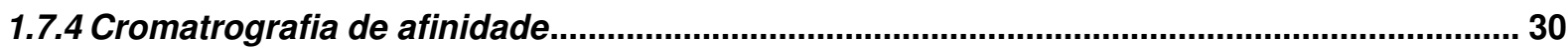

2 OBJETIVOS

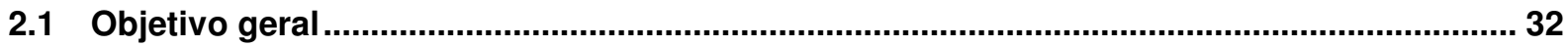

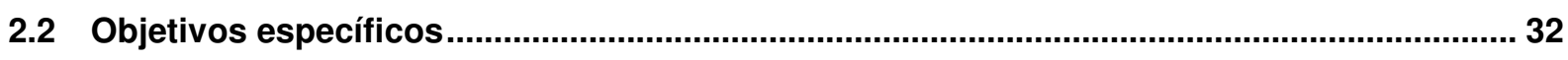

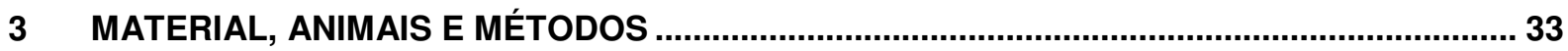

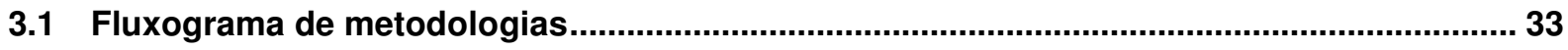

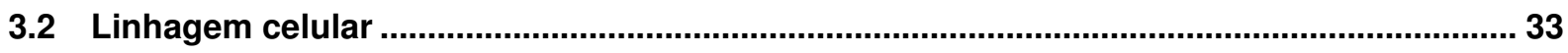

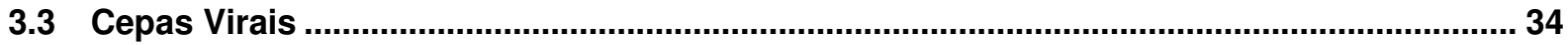

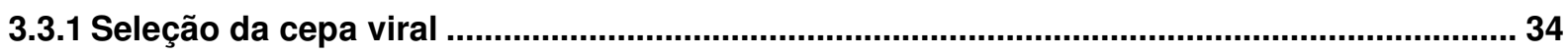

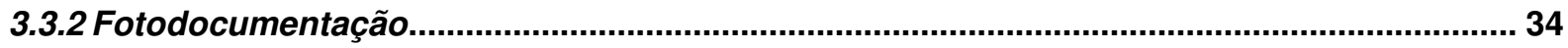

3.4 Produção de vírus para obtenção de ribonucleoproteínas.................................................. 35

3.4.1 Replicação de vírus em sistema estático de cultura celular............................................... 35 
3.4.2 Replicação de vírus em sistema roller de cultura celular ................................................... 36

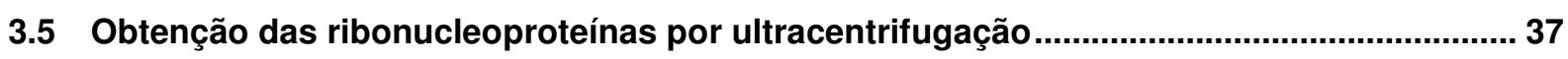

3.5.1 Determinação da concentração protéica das ribonucleoproteínas ...................................... 38

3.5.2 Confirmação da presença de ribonucleoproteínas........................................................... 38

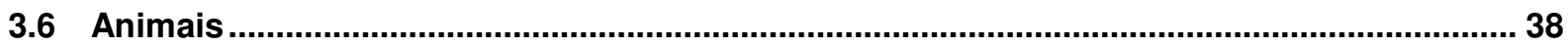

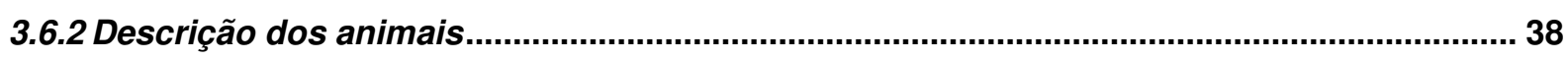

3.7 Obtenção de soro hiperimune antirribonucleoproteínas ................................................ 38

3.7.1 Avaliação de anticorpos antirribonucleoproteínas................................................................ 39

3.8 Purificação dos anticorpos por cromatografia de troca iônica .......................................... 40

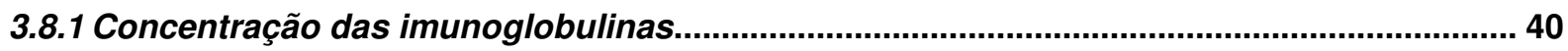

3.9 Purificação dos anticorpos por cromatografia de afinidade ............................................. 41

3.9.1 Confirmação da pureza das imunoglobulinas por eletroforese ........................................ 41

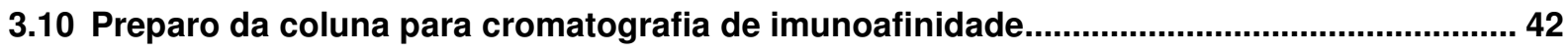

3.11 Obtenção de ribonucleoproteínas por cromatografia de imunoafinidade .......................... 43

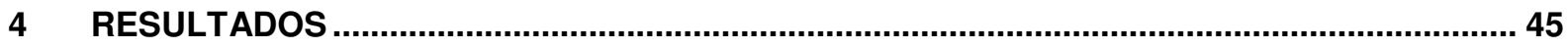

4.2 Replicação de vírus em sistema estático de cultura celular................................................46

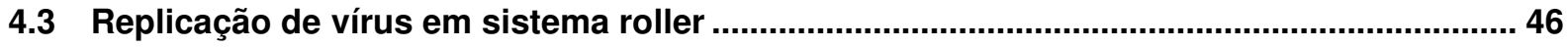

4.4 Obtenção das ribonucleoproteínas por meio de ultracentrifugação ................................. 46

4.5 Avaliação dos soros hiperimunes antirribonucleoproteínas.............................................. 47

4.6 Purificação dos anticorpos por cromatografia de troca iônica .............................................48

4.7 Purificação dos anticorpos por cromatografia de afinidade .............................................. 48

4.8 Cromatografia de imunoafinidade para obtenção de ribonucleoproteínas ........................50

4.9 Obtenção de ribonucleoproteínas por cromatografia de imunoafinidade ..........................50

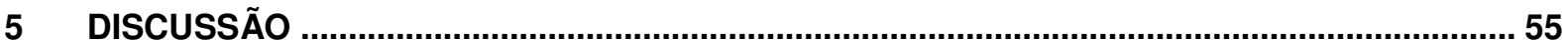

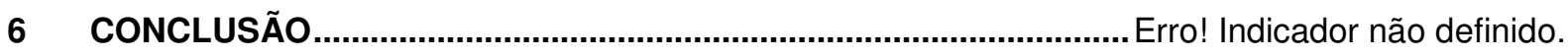

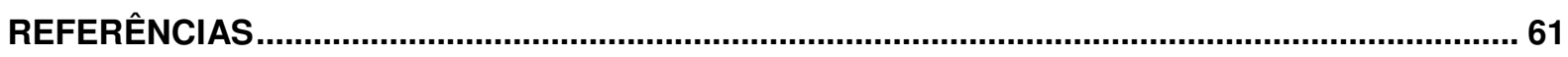

ANEXO 


\section{INTRODUÇÃO}

\subsection{A raiva: considerações gerais}

Definida como uma doença negligenciada no mundo todo (Fooks et al., 2003; Dodet, 2006) e embora possa ser prevenida com a utilização de esquemas vacinais (Briggs, Hanlon, 2007), a raiva está entre as dez principais causas de morte humana dentre as doenças infecciosas (World Health Organization, 2000).

É uma zoonose que apresenta um prognóstico letal e mesmo com todos os subsídios existentes para o seu controle e com o advento da vacina antivírus da raiva, produzida há 125 anos por Pasteur, é ainda considerada um grave problema de saúde pública, principalmente em países em desenvolvimento, onde os casos não são habitualmente notificados, dificultando assim o conhecimento da sua real incidência (Coleman et al., 2004).

A importância da raiva para saúde pública não se deve apenas ao número de casos, mas também à alta mortalidade e aos elevados custos com tratamentos (Kaplan et al., 1986), diagnósticos e reações adversas às vacinas (WHO, 2005).

Estima-se que o Governo do Brasil gaste anualmente US\$28 milhões na profilaxia e controle da raiva, apenas com vacinas de uso humano e veterinário para cães, imunoglobulinas, diagnóstico laboratorial, treinamento de recursos humanos e campanhas de vacinação de cães. Nesse valor não estão incluídas as despesas relacionadas à prevenção da raiva transmitida pelos morcegos hematófagos a humanos e herbívoros (Childs, Real, 2007).

O vírus da raiva tem sido isolado da maioria das ordens de mamíferos e juntamente com os morcegos (Ordem Chiroptera), os canídeos (Ordem Carnivora) são considerados os principais reservatórios silvestres do vírus da raiva (Rupprecht et al., 2002).

A raiva está difundida em todos os continentes, com exceção da Antártida. Os países ou pequenas ilhas como a Antígua, Austrália, Bahamas, Barbados, Bermuda, Ilhas Cayman, Fiji, Finlândia, Islândia, República da Irlanda, Jamaica, Japão, Nova Zelândia, Noruega, Saint Kitts-Nevis-Anguilla, Santa Lúcia, Saint Martin (Antilhas Holandesas), Ilhas São Pedro e Miquelon, São Vicente, Suécia, Taiwan, Turquia e 
Ilhas Caico, Reino Unido, e Uruguai são considerados livres da raiva clássica (Canadian Food and Inspection Service, 2010).

Dietzschold et al. (2008) relatam que ocorrem aproximadamente 70.000 óbitos humanos por raiva no mundo, porém a Organização Mundial da Saúde (OMS) estima que anualmente ocorram aproximadamente, 55.000 óbitos por raiva, principalmente nas áreas rurais dos continentes asiático e africano (WHO, 2005). Na América Latina, a incidência anual da raiva por 100.000 habitantes varia entre $0 \mathrm{e}$ 0,09 na América do Sul; 0 e 0,10 na América Central e 0 e 0,06 nas ilhas do Caribe. $\mathrm{Na}$ grande maioria dos casos, o cão foi identificado como o principal animal agressor (Childs, Real, 2007).

No Brasil, no período de 1986 até final de 2009, ocorreram 763 óbitos por raiva humana, sendo que destes, 518 tiveram o cão como principal animal agressor, seguido dos quirópteros que foram responsáveis por 135 casos. Entre 1980 e 2003, houve uma significativa redução no número de casos de raiva humana registrados por ano, caindo de 173 para 17, representando uma diminuição de $90 \%$ dos casos. De 1990 a 2009 foram notificados 573 casos de raiva humana em vinte e uma unidades federativas, sendo que $82 \%$ dos casos ocorreram nas regiões Norte e Nordeste do país. Nos anos de 2004 e 2005 foram 74 óbitos causados pela raiva, ocorridos nessas regiões, tendo como principal transmissor o morcego hematófago. Em 2006 houve um decréscimo de casos (09). Em 2007 ocorreu apenas um caso. Em 2008, dos três casos de raiva humana ocorridos, um recebeu tratamento baseado no protocolo de Milwaukee (Willoughby et al., 2005), que consiste no uso de antivirais e indução do paciente ao coma, o qual foi o primeiro caso de cura de raiva no Brasil. No ano de 2009 ocorreram dois óbitos por raiva humana na região Nordeste, sendo o cão o animal agressor e em 2010 até o mês de maio ocorreu 1 caso de óbito humano por raiva transmitida por morcego (Figura 1) (Brasil, 2010). 


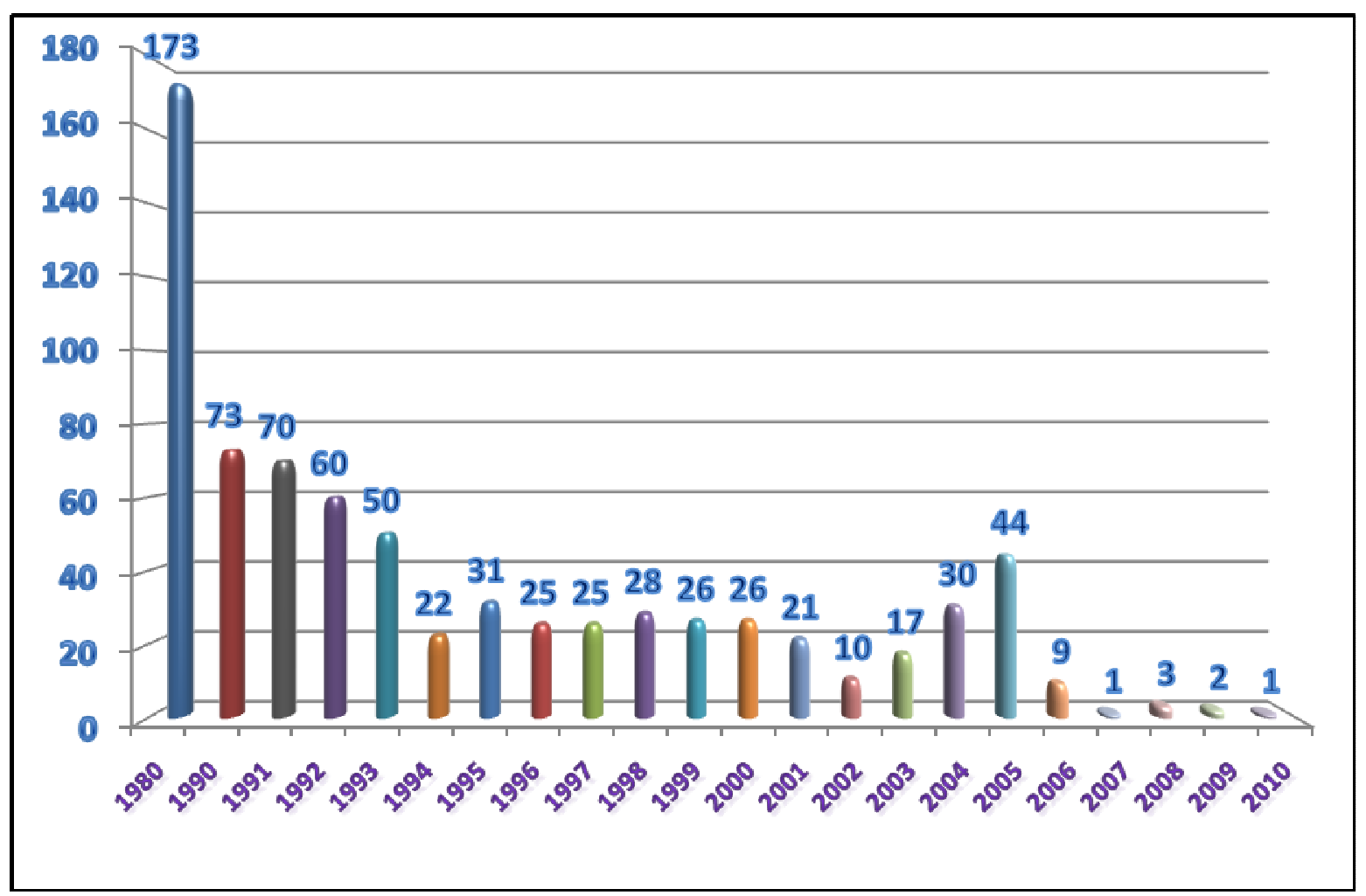

Figura 1. Casos de raiva humana diagnosticados no Brasil no período de 1980 a 2010*. *até o mês de maio de 2010

\subsection{Vírus da raiva}

O vírus da raiva, pertence ao gênero Lyssavirus e família Rhabdoviridae a qual junto com as Famílias Paramyxoviridae, Filoviridae e Bornaviridae, constitui a Ordem Mononegavirales (International Committee on Taxonomy of Viruses - ICTV, 2010).

Em 2009, o Comitê Internacional de Taxonomia Viral - ICTV definiu 11 espécies virais para o gênero Lyssavirus: Rabies virus (RABV), Lagos bat virus (LBV), Mokola virus (MOKV), Duvenhage virus (DUVV), European bat lyssavirus $1 \mathrm{e}$ European bat lyssavirus 2 (EBLV1 e EBLV2), Australian bat lyssavirus (ABLV), Aravan virus (ARAV), Khujand virus (KHUV), Irkut virus (IRKV) e West Caucasian bat virus (WCBV) (ICTV, 2010; Carstens, 2010).

A espécie Rabies virus compreende as cepas clássicas vacinais, chamadas "fixas" ou laboratoriais, e os isolados de vírus da maioria dos mamíferos terrestres e de morcegos hematófagos, insetívoros e frugívoros das Américas. Apresenta maior importância epidemiológica por sua associação com um grande número de casos de raiva em relação a outras espécies e por ser mais amplamente distribuída no mundo 
(Tordo, 1996; Wunner, 2002). No continente americano e no Caribe, até o momento só foi evidenciada a presença da espécie Rabies virus (Fooks, 2004).

\subsubsection{Estrutura e morfologia do vírus da raiva}

A média do comprimento do vírus da raiva é de 180 nanômetros $(\mathrm{nm})$ (variando de 130 a $250 \mathrm{~nm}$ ) e a média do diâmetro é $75 \mathrm{~nm}$, que pode variar entre 60 e 110 nm (Wunner, 2007). Sua morfologia é baciliforme, semelhante à "bala de revolver", com uma extremidade arredondada e a outra plana, sendo constituído de nucleocapsídeo helicoidal ou ribonucleoproteínas (RNP) e o envelope viral coberto de glicoproteínas espiculadas (Kaplan, 1996).

A RNP é filamentosa, composta por uma fita simples de RNA genômico de forma helicoidal não segmentado e de senso negativo, associadas às nucleoproteínas (N), fosfoproteína (P) e RNA-polimerase viral (L) (Tordo et al., 1986; Fauquet et al., 2004). A figura 2 demonstra o complexo ribonucleoproteíco do vírus da raiva.

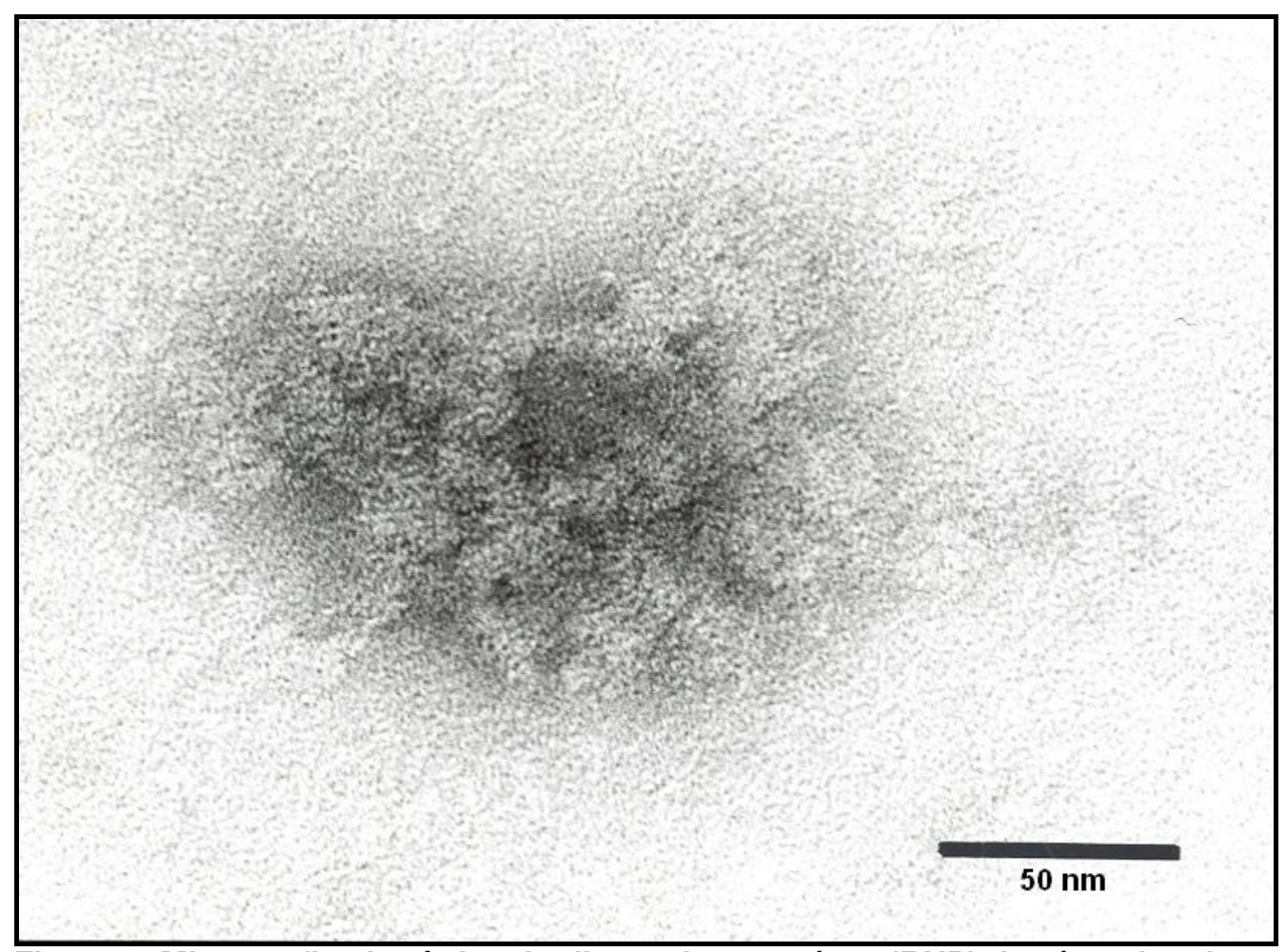

Figura 2. Micrografia eletrônica de ribonucleoproteínas (RNP) do vírus da raiva. Fonte: Caporale et al., 2009 
A composição dos vírus para as diferentes espécies do gênero Lyssavirus é formada por cinco proteínas estruturais: nucleoproteína $(N)$, fosfoproteína $(P)$, proteína de matriz $(M)$, glicoproteína $(G)$ e a RNA-polimerase $(L)$, de modo que a partícula viral completa contém de 2 a $3 \%$ de ácido ribonucléico (RNA), entre 67 e $74 \%$ de proteínas, 20 e $26 \%$ de lipídeos e $3 \%$ de carboidratos (Wunner, 2007).

O envelope viral é constituído por uma bicamada lipídica, à qual estão associadas duas proteínas: a proteína M e a glicoproteína G. A glicoproteína é uma proteína transmembranária projetando-se para o exterior com espículas glicosiladas em forma de trímeros (Wunner et al., 1985).

A estrutura morfológica do vírus da raiva está esquematizada na figura 3.

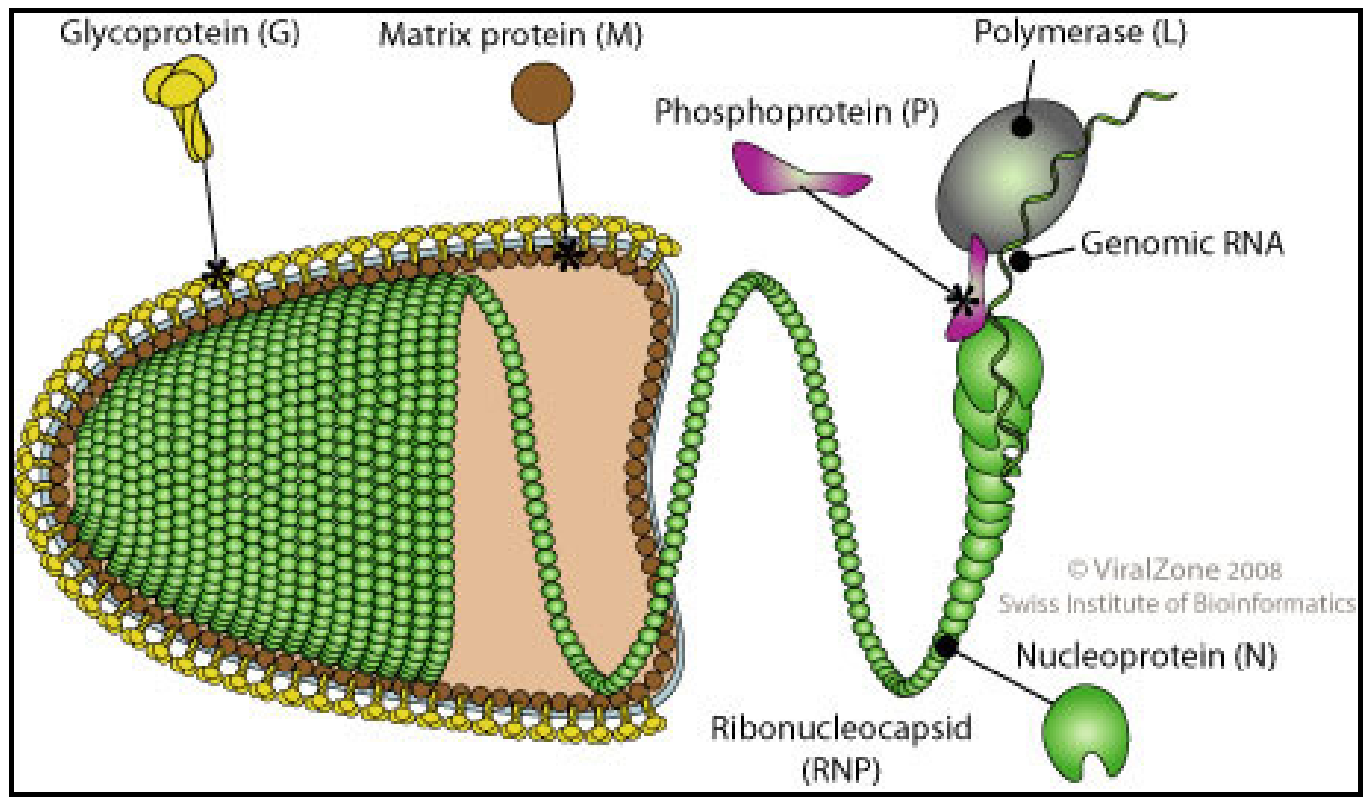

Figura 3. Representação esquemática do vírus da raiva.

RNP com genoma RNA fita simples, proteína de nucleocapsídeo (N), RNApolimerase $(L)$ e fosfoproteína. $(P)$. O core RNP associado com a proteína de matriz $(M)$ e espículas triméricas de glicoproteína $(G)$ envolvendo a estrutura RNP (envelope viral).

Fonte: Swiss Institute of Bioinformatics, 2010.

A proteína $\mathrm{N}$ e o gene que a codifica são os componentes moleculares mais conservados em termos de identidade de sequência de aminoácidos (aa) e nucleotídeos (nt), dentro de cada espécie viral, apesar da relativa alta diversidade entre pequenas regiões do gene $N$ (Ertl et al., 1989; Wunner, 2002) e por estas razões é a mais utilizada em diagnósticos e estudos das relações evolutivas e epidemiológicas (Tordo, Kouknetzoff, 1993). Uma razão importante para o alto nível de conservação da sequência de aa, principalmente dentro de regiões específicas 
em N, deve estar ligada ao fato desta proteína desempenhar funções fundamentais no vírus (Wunner, 2007). Provavelmente, a conservação genética de $\mathrm{N}$ ao longo do tempo ocorre pelos seguintes fatores: interage com o RNA encapsidando-o; é a mais abundante proteína do capsídeo; protege o genoma contra nucleases celulares; regula a replicação; modula a transcrição e interage com a fosfoproteína $\mathrm{P}$ durante a replicação e tradução (Wunner, 2002). A proteína $\mathrm{N}$ também é a mais conservada antigenicamente, e por estas razões é a mais utilizada em diagnósticos e estudos das relações evolutivas e epidemiológicas (Tordo, Kouknetzoff, 1993).

A nucleoproteína $\mathrm{N}$ é um polipeptídio constituído de 450 aa, e apresenta massa molecular de aproximadamente 57 kilodaltons (kDa) (Tordo et al., 1986). O maior grau de similaridade entre sequências de aa (98-99\%) ocorre entre as diferentes cepas de vírus da raiva. Os vírus que apresentam menos que $80 \%$ de similaridade na sequência de nt ou menos que $92 \%$ na sequência de aa pertencem a diferentes espécies virais (Kissi et al., 1995; Wunner, 2002).

Tanto na espécie Rabies virus como nas demais espécies virais de lissavirus, a glicoproteína G é composta por quatro domínios distintos, o domínio peptídeo sinal (PS), o ectodomínio (ED), domínio transmembrana (TM) e o domínio citoplasmático (DC). A glicoproteína G madura, isto é, sem o PS é constituída por 505 aa e massa molecular aproximadamente de $65 \mathrm{kDa}$. É a proteína de fusão, atuando na adsorção viral a receptores específicos nas células dos hospedeiros, possibilitando a entrada do vírus na célula. Além disso, é altamente imunogênica, sendo fundamental para a resposta imune contra o vírus da raiva, induzindo a produção de anticorpos neutralizantes $(\mathrm{AcN})$, ativação de linfócitos $\mathrm{T}$ auxiliares e $\mathrm{T}$ citotóxicos e atua na patogênese da doença (Wunner, 2007).

A proteína P é um polipeptídeo fosforilado que contém 297 aa, é altamente conservado (maior que 97\%) entre os lissavirus da espécie Rabies virus. Possui massa molecular entre 38 e $41 \mathrm{kDa}$, interage com as proteínas $\mathrm{N}$ e L e acredita-se que atue como cofator da RNA polimerase (Wunner, 2007). A proteína $P$ é multifuncional, ligando-se a outras proteínas virais para auxiliar na replicação do genoma viral e também interagir com fatores celulares e, possivelmente, está associada na disseminação e patogênese viral (Lafon, Wiktor, 1985; Mebatsion, 2001). 
A proteína M é a menor do vírus da raiva e contém aproximadamente 202 aa com massa molecular de $25 \mathrm{kDa}$ (Tordo et al., 1986; Ameyama et al., 2003). Aproximadamente de 1200 a 1500 moléculas de proteína M se ligam as RNP, condensando-a e formando o arcabouço do virion. O tropismo da RNP pela membrana celular é determinado por esta proteína, possibilitando seu brotamento (Mebatsion et al., 1999). Além da presença de M ligada na RNP ser responsável pelo brotamento do vírus, a interação desta proteína com a proteína $\mathrm{G}$, presente nas membranas celulares, estimula fortemente esse processo (Mebatsion et al., 1999).

A RNA-polimerase L é a maior proteína do vírus, com 2.142 aa e massa molecular de $244,2 \mathrm{kDa}$, originando assim o nome "large". É responsável pelas atividades enzimáticas necessárias à transcrição e replicação do RNA viral (Tordo et al., 1988). A proteína $L$ é o componente catalítico do complexo polimerase que, juntamente com o cofator $P$, é responsável pela maioria das atividades enzimáticas que ocorrem tanto na transcrição quanto na replicação do genoma do vírus da raiva.

Estudos de outros vírus RNA com sentido negativo auxiliaram a determinar áreas do gene $\mathrm{L}$, com o objetivo de localizar sequências genéticas deste gene, responsáveis pelas atividades enzimáticas da polimerase $L$ (Tordo et al., 1986; Barik et al., 1990; Poch et al., 1990).

Uma das principais características de $L$ é a existência de agrupamentos de aa conservados em blocos ao longo da proteína (Poch et al., 1990). Nestes blocos alguns aa formam domínios conservados, enquanto outros não o são (Tordo, Poch, 1988; Banerjee, Chattopadhyay, 1990; Poch et al., 1990).

Outras funções da RNA-polimerase viral incluem: a adição de 7metilguanosina $\left(m_{7} G\right)$ no final 5 , adição de grupo metila no RNA e formação da cauda poli-A. (Schnell, Conzelmann, 1995).

\subsubsection{Replicação do vírus da raiva}

Os eventos sequenciais do ciclo de replicação do vírus da raiva na célula hospedeira são semelhantes aos de muitos outros vírus, ou seja: adsorção, penetração, transcrição, tradução, replicação, maturação e liberação por brotamento (Fauquet et al., 2005). Todas as fases intracelulares ocorrem no citoplasma celular, motivo pelo qual o genoma do vírus possui o gene $L$. Os genes estruturais do vírus 
apresentam diferentes funções de acordo com o estágio da infecção (Wunner, 2007).

O vírus liga-se a receptores celulares, proteínas de membrana, por meio das espículas formadas por trímeros de proteína $G$ encontradas sobre a superfície do envelope do vírus (Lafon, 2005).

A adsorção não é dependente de temperatura, mas de pH sendo o pH $6.3 \circ$ mais favorável, pois este determina pequenas mudanças conformacionais em $\mathrm{G}$. As espículas, em pH ácido mudam de conformação tornando-se mais compridas e irregulares. Esta mudança é reversível e de novo em pH 7.0 retomam a sua conformação original (Gaudin et al., 1995).

Em relação ao neurotropismo é provável que o vírus reconheça receptores de membrana, como o receptor nicotínico de acetilcolina $(\mathrm{nAChR})$, encontrado nas junções neuromusculares, os possíveis locais de entrada do vírus no Sistema Nervoso (Lentz et al., 1982). Outros dois receptores descritos como importantes para a entrada do vírus na célula hospedeira são a molécula de adesão de neurônios CD56 ("neural cell adhesion molecule" - NCAM ou NCAM1) (Thoulouze et al., 1998) e o receptor de neurotrofina de baixa afinidade ("low-affinity neurotrophin receptor" p75NTR, BEX3 ou NGFR) (Tuffereau et al., 1998).

A penetração do vírus é dependente de temperatura, sendo a temperatura ótima $37{ }^{\circ} \mathrm{C}$. A endocitose é a hipótese aceita para explicar a entrada do vírus na célula (Klingen et al., 2008). Cada uma das vesículas endocíticas incorpora entre dois e cinco virions (Tsiang, 1993; Gaudin et al., 1993).

No interior da célula ocorre a decapsidação do virion, ou seja, a liberação da RNP no citoplasma. O baixo $\mathrm{pH}$ interno do vacúolo digestivo, formado pela união do endossomo mais lisossomo celular faz com que a membrana do vacúolo una-se à membrana do envelope do vírus. Esta união membranosa aumenta a pressão interna do virion, ejetando a RNP diretamente no citoplasma. Desta forma, o genoma não é lesado pelo suco digestivo dos lisossomos e também pelas nucleases e proteases celulares, pois são protegidos pelo próprio endossomo (Gosztonyi, 1994, Wunner, 2007). Uma vez a RNP livre no citoplasma ocorre a transcrição e a replicação das proteínas virais (Iseni et al., 1998). 
A RNA-polimerase inicia a transcrição dos cinco genes estruturais do vírus. A transcrição do RNA genômico ocorre da extremidade 3' em direção à extremidade 5', produzindo primeiro um RNA líder e depois cinco RNA mensageiros que correspondem às proteínas $\mathrm{N}, \mathrm{P}, \mathrm{M}, \mathrm{G}$ e L. Em seguida, há uma segunda etapa replicativa na qual as fitas positivas serão moldes para a produção de fitas negativas complementares (Banerjee, 1987).

Todas as proteínas virais são transcritas e traduzidas simultaneamente. As proteínas N, P, M e L são traduzidas nos ribossomos livres do citoplasma, enquanto a tradução da proteína $\mathrm{G}$ ocorre nos ribossomos ligados à membrana do retículo endoplasmático rugoso (RER) (Gaudin et al., 1992).

A montagem do vírus no citoplasma da célula hospedeira tem início com a associação das proteínas N, P e L ao RNA genômico recém sintetizado, formando a RNP. As proteínas M seguem em dois sentidos: uma parte une-se a RNP enquanto a outra se insere na membrana plasmática da célula hospedeira, preparando-a para a liberação dos vírions. A RNP associada à membrana plasmática estimula a liberação do vírion por brotamento. Anteriormente ao brotamento do vírion, a transcrição e replicação viral são inibidas pela ação da proteína $M$, bloqueando a síntese de RNA. A pressão interna desse aglomerado nucleoprotéico sobre a membrana plasmática determina que esta região formada destaque-se da célula, ocorrendo o brotamento do vírus da raiva (Meslin et al., 1996).

Nos estágios finais, a partícula viral madura é revestida com a membrana plasmática celular, formando juntamente com a glicoproteína, o envelope viral e finalmente liberando novas partículas virais infectantes (Wunner, 2002).

A representação do ciclo da replicação do vírus da raiva está esquematizada na figura 4. 


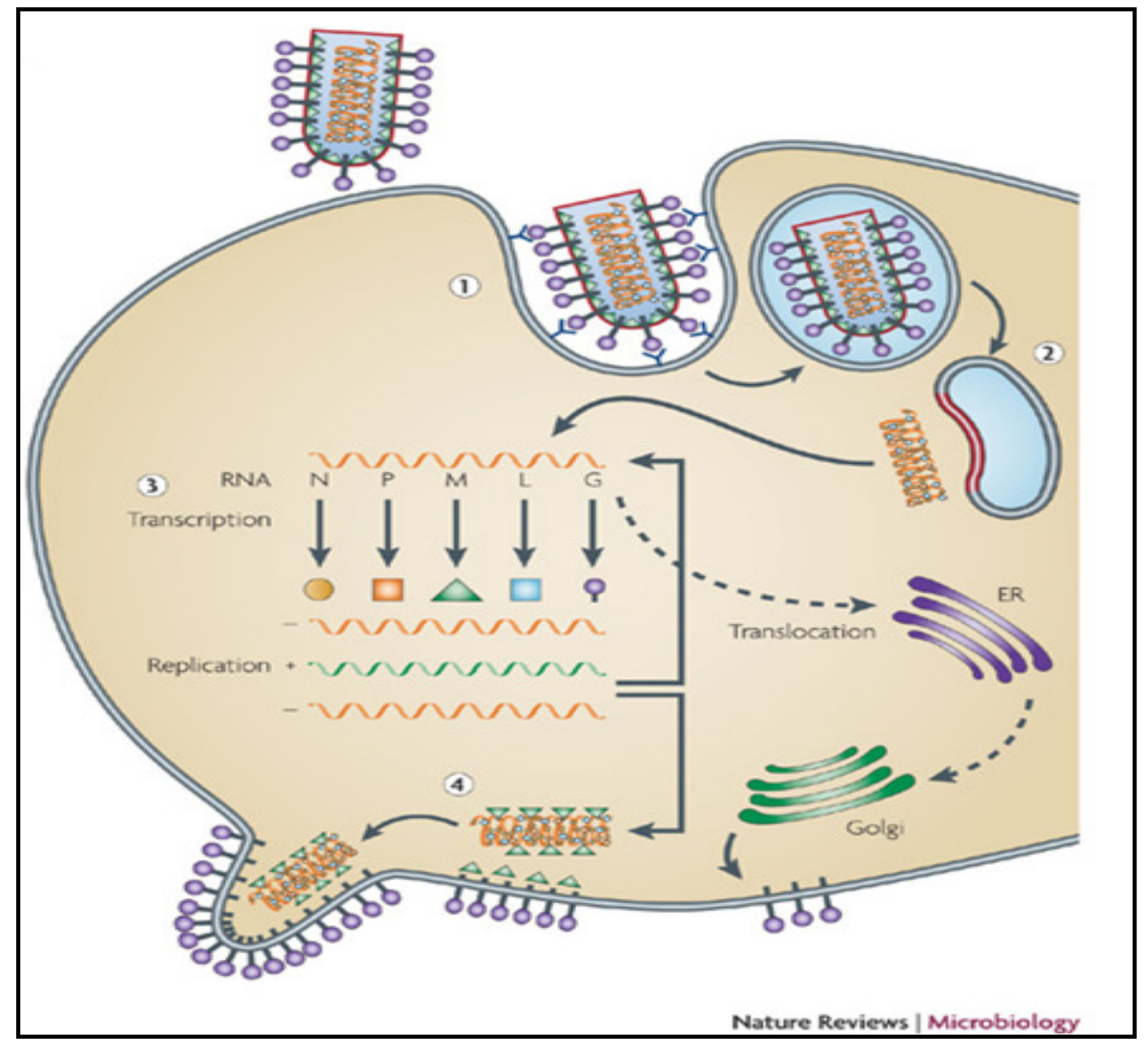

Figura 4. Representação simplificada do ciclo de replicação do vírus da raiva.

1- Adsorção e Penetração por endocitose na célula hospedeira; 2- Fusão da membrana viral e membrana do endossomo para a liberação do genoma viral; 3- Produção dos componentes virais: transcrição, replicação e síntese protéica e 4- Montagem dos componentes virais, brotamento e liberação de novas partículas virais infectantes. ER. Retículo Endoplasmático.

Fonte: Schnell et al., 2010.

\subsection{Patogenia do vírus da raiva}

A patogenia do vírus da raiva inclui os seguintes passos no organismo de um indivíduo suscetível: replicação inicial do vírus na porta de entrada usualmente constituída por uma lesão da pele, migração pelos nervos periféricos até o sistema nervoso central (SNC), de onde o vírus se dissemina, infectando outros tecidos fora do SNC, causando lesões irreversíveis, levando à morte do hospedeiro. O vírus não penetra pela pele intacta, a infecção depende do contato do vírus com soluções de continuidade da pele, já existentes ou provocadas por mordeduras ou arranhaduras, entre outras, ou com membranas mucosas como: nariz, olhos ou boca (Acha, Szyfres, 2003; Brass, 1994). 
Outras portas de entrada são raras, porém, em 1956, foi registrado um caso de raiva humana, em um indivíduo que trabalhava em cavernas habitadas por morcegos, porém sem histórico de mordedura ou outro contato com algum animal suspeito. Após investigação epidemiológica, propôs-se a hipótese de que o indivíduo se infectara por inalação de partículas virais em suspensão na caverna (Brass, 1994; Warrell, Warrell, 2004). A infecção por via aérea também foi demonstrada, em condições naturais, quando animais sadios foram colocados dentro de grutas onde viviam grandes colônias de morcegos infectados (Constantine, 1962). A detecção de antígenos do vírus da raiva em receptores de células olfatórias de morcegos naturalmente infectados em cavernas, sugerindo que a mucosa nasal era a porta de entrada em infecções de morcegos foi relatada por Constantine, Emmons e Woodie ${ }^{1}$ (1972), apud Baer (1975, p. 86). Para que ocorra a transmissão por via aerógena, é necessária uma grande população de morcegos infectados em áreas não ventiladas (Jackson, 2002).

Após alcançar o SNC, o vírus migra centrifugamente em direção aos diferentes órgãos, envolvendo particularmente o sistema nervoso parassimpático. (Jackson, 2002). Os órgãos invadidos pelo vírus durante a migração centrífuga incluem o coração, fígado, pele, timo, rins, ovários, útero, glândula adrenal, pulmão, baço, intestinos, músculos liso e esquelético, folículos pilosos, epitélio da língua, retina e córnea (Brass, 1994; Mattos etal., 2001).

\subsection{Diagnóstico laboratorial da raiva}

O diagnóstico da raiva baseado na observação clínica encontra dificuldades, principalmente em animais, por ser confundida com outras encefalites que também podem ser causadas por infecções virais. Em humanos, a raiva pode ser confundida com a síndrome de Guillain-Barré, poliomielite, e outras encefalites virais (Plotkin, 2000). Portanto o diagnóstico laboratorial da raiva é de fundamental importância para a confirmação do caso suspeito.

O diagnóstico laboratorial da raiva deve ser rápido e preciso, uma vez que os resultados laboratoriais influenciam não só a decisão médica de se instituir o

\footnotetext{
${ }^{1}$ Constantine DG, Emmons RW, Woodie JD. Rabies virus in nasal mucosa of naturally infected bats. Science. 1972;175:1255-1256.
} 
tratamento profilático em humanos, como também a elaboração de medidas de controle de uma possível epizootia em uma comunidade (Meslin, Kaplan, 1996).

As técnicas diagnósticas devem apresentar elevada sensibilidade e especificidade bem como rapidez na obtenção dos resultados. Portanto é recomendada na rotina laboratorial de diagnóstico a utilização de duas ou mais técnicas associadas, aumentando dessa maneira a confiabilidade dos resultados obtidos (Kotait et al., 2009).

Inclusões citoplasmáticas chamadas de corpúsculos de Negri, observadas por Adelchi Negri, em 1903, em células do SNC infectadas pelo vírus da raiva, são o sinal patognomônico da doença (Perl, Good 1991; Lépine, Atanasiu, 1996).

Em 1927, foi utilizada no diagnóstico da raiva a coloração de Sellers, que consistiu na observação dos corpúsculos de Negri, por meio de um corante adequado, corante de Sellers (Rupprecht et al., 2002). Essa técnica não é mais utilizada rotineiramente, visto que a OMS tem recomendado o isolamento viral e a imunofluorescência direta para o diagnóstico laboratorial da raiva (Tierkel, Atanasiu, 1996).

Com recentes desenvolvimentos tecnológicos, a evidência da existência da infecção pelo vírus da raiva pode ser demonstrada por detecção de vírus inteiro, proteínas virais ou RNA viral em amostras de órgãos ou tecidos neurais ou não neurais. Os métodos empregados incluem microscopia eletrônica (ME), teste de imunofluorescência direta (IFD), teste de imunofluorescência indireta (IFI), cultivo de vírus in vivo e em in vitro, imunohistoquímica, ensaio imunoenzimático, hibridização molecular com ácidos nucléicos ligados por meio de sondas e reação em cadeia pela polimerase (RT-PCR). Evidências indiretas da infecção pelo vírus da raiva podem ser inferidas pela demonstração de AcN específicos, em soros ou em fluído cérebro-espinhal de indivíduos não vacinados (Trimarchi, Smith, 2002; Chaves et al., 2007). O teste de IFD realizado para a detecção de vírus da raiva é usado como método preferencial, em escala global (Rudd et al., 2005), sendo também o teste revelador em cultura de células, tanto para o isolamento viral como na avaliação de títulos de AcN.

Atualmente no Brasil são realizados mais de 60.000 testes diagnósticos por ano para a detecção do vírus em amostras de SNC de animais suspeitos. Somente 
no Instituto Pasteur de São Paulo (IP-SP) são realizados aproximadamente 15.000 diagnósticos dessas amostras e 25.000 amostras de soro humano para avaliação dos níveis de $\mathrm{AcN}$, em resposta à vacinação de indivíduos expostos ao risco de infecção pelo vírus da raiva. ${ }^{2}$

\subsubsection{Detecção do vírus da raiva por imunofluorescência direta}

O teste de imunofluorescência consiste em uma reação sorológica na qual, para se detectar a reação antígeno-anticorpo, utiliza-se um sistema revelador, chamado conjugado, que é uma substância fluorescente (fluorocromo), ligada ao anticorpo. Esta reação deve ser visualizada ao microscópio de fluorescência. Determinadas substâncias fluorescentes, como o isotiocianato de fluoresceína (ITCF), possuem a propriedade de absorver luz de determinado comprimento de onda (luz ultravioleta) e emitir luz de comprimento de onda maior (luz verde). Os antígenos reagentes com o anticorpo marcado, no caso do vírus da raiva, aparecem como partículas ou corpúsculos, ovalados ou arredondados, intracitoplasmáticos (Webster, Casey 1988; Dean et al., 1996).

O teste de IFD, considerado "padrão ouro" para o diagnóstico da raiva (Rupprecht et al., 2002), é realizado em SNC de várias espécies animais suspeitas de infecção pelo vírus da raiva e para controle epidemiológico da doença.

\subsubsection{Isolamento viral}

Em 1935, Webster e Dawson preconizaram a inoculação intracerebral de camundongos (IIC) para o diagnóstico e para a avaliação sorológica da raiva. A utilização de camundongos albinos suíços apresenta alta sensibilidade, porém com resultados demorados, uma vez que o período de incubação do vírus de rua, nesses animais, varia de 7 a 21 dias.

O primeiro relato de isolamento do vírus da raiva em cultura de células foi em 1930 (King, 1996). Tais estudos demonstraram que essa técnica também apresentava alta sensibilidade, com a vantagem de reduzir substancialmente 0 tempo para obtenção dos resultados, entre 72 e 96 horas, e apresentar menor custo, quando já se tenha um laboratório de cultivo celular implantado, pois dispensa a manutenção de animais de laboratório.

\footnotetext{
${ }^{2}$ Dados fornecidos pelo Programa de Controle da Raiva
} 
As células de neuroblastoma murino (N2A - C 1300) apresentam maior sensibilidade à infecção que outras linhagens celulares (Clark, 1978; King, 1996; Webster, Casey, 1996). A confirmação do isolamento do vírus da raiva nessas linhagens celulares é feita pela ligação de anticorpos conjugados a substância fluorescente aos antígenos do vírus da raiva.

\subsubsection{Avaliação sorológica}

A avaliação do título de anticorpos é de fundamental importância para determinar a proteção do indivíduo à raiva após a vacinação, seja em situações de pré ou pós-exposição.

Devem ser levados em conta vários fatores para se determinar o teste de avaliação sorológica mais adequado aos laboratórios que realizam o diagnóstico da raiva, de acordo com a infra-estrutura e equipamentos disponíveis. No entanto, os únicos testes recomendados pela OMS são aqueles que avaliam a presença de AcN (Trimarchi et al., 1996)

Foram desenvolvidos muitos testes para avaliação de anticorpos e estão disponíveis atualmente, tais como imunofluorescência indireta (Thomas, Sikes e Ricke, 1963), contra-imunoeletroforese (Diaz et al.,1986) e ELISA (Piza et al., 1999) entre outros, entretanto esses testes avaliam a presença de anticorpos contra todas as proteínas do vírus.

Embora o teste de soroneutralização em camundongos (Webster, Dawson, 1935) continue sendo utilizado em muitos laboratórios por não necessitar de equipamentos especializados, apresenta desvantagens para uma rotina com grande número de amostras de soros, pelo uso elevado de animais e demora na obtenção dos resultados.

Testes "in vitro" que avaliam o título de AcN utilizando células Baby Hamster Kidney (BHK-21) para a infecção viral, foram desenvolvidos, como o teste rápido de inibição de focos fluorescentes (RFFIT), (Smith et al., 1973), o qual foi modificado por Zalan et al. (1979), chamado de microteste de inibição de fluorescência (FIMT), possibilitando o processamento de um grande número de amostras de soros. Baseado nestes estudos, foi desenvolvido no IP-SP um microteste simplificado de inibição de focos fluorescentes (SFIMT) (Favoretto et al., 1993), atualmente utilizado 
no Brasil, rotineiramente, na avaliação da imunidade de indivíduos vacinados contra o vírus da raiva.

\subsection{Conjugado fluorescente antivírus da raiva}

A obtenção de conjugado fluorescente antivírus da raiva é realizada por meio da conjugação do fluorocromo isotiocianato de fluoresceína (ITCF) a anticorpos específicos purificados. O ITCF é o fluorocromo mais utilizado na produção de conjugados a serem usados na técnica de imunofluorescência para o diagnóstico da raiva, por sua estabilidade e por apresentar fluorescência característica, em que os anticorpos aparecem à luz ultravioleta, como partículas brilhantes de cor maçã-verde sobre um fundo escuro (Dean, Abelseth, 1973).

Os conjugados fluorescentes usados para revelação dos testes diagnósticos de IF, seja para detecção do vírus da raiva em SNC de animais ou humanos; ou para os testes realizados em cultura celular para isolamento viral e avaliação sorológica (soroneutralização), são, geralmente, provenientes de soros hiperimunes de animais imunizados com vacinas, partículas inteiras de vírus ou RNP purificadas. Outra possibilidade surgiu com a introdução da tecnologia de hibridomas, por Köhler e Milstein em 1975, que permitiu a produção de conjugados puros e específicos, preparados a partir de um coquetel de anticorpos monoclonais (AcM). Entretanto, a produção dos conjugados derivados de AcM requer rigidez na execução dos protocolos estabelecidos para a obtenção dos referidos anticorpos (Rudd et al., 2005).

Com a purificação de partículas inteiras de vírus da raiva e RNP, para serem usados como antígenos de imunização, foi possível obter soros de coelhos com altos títulos de anticorpos específicos. Imunoglobulinas $\mathrm{G}(\lg \mathrm{G})$ purificadas puderam ser obtidas rapidamente usando a técnica de cromatografia de troca iônica em coluna de QAE-Sephadex A50, para posterior conjugação ao ITCF (Joustra, Lundgren, 1969). Isso resultou num reagente melhor do que aqueles obtidos com base em métodos como precipitação com sulfato de amônio, etanol ou outros previamente desenvolvidos de fracionamento de soros (Atanasiu et al., 1974).

Os conjugados produzidos a partir de soros de animais imunizados com RNP purificadas são altamente específicos pelo fato da nucleoproteína ser a mais conservada estruturalmente e ter o maior grau de conservação nas amostras fixas 
do vírus da raiva. É também a mais conservada antigênicamente, e por estas razões é a mais utilizada para diagnóstico e estudos das relações evolutivas e epidemiológicas (Tordo, Kouknetzoff, 1993; Wunner, 2002).

\subsection{Purificação do vírus da raiva e ribonucleoproteinas}

O advento da infecção de cultura de células com o vírus da raiva permitiu sua replicação em larga escala para a extração e purificação de partículas virais inteiras e subunidades do vírus, tal como RNP virais, empregando metodologia de ultracentrifugação em gradiente de sacarose e gradiente de cloreto de césio, padronizada por Compans e Choppin, em 1967 e modificada por Sokol et al., em 1973.

Embora essa metodologia permita a obtenção das proteínas desejadas e possa ser aplicada de maneira satisfatória nos procedimentos empregados para produção de imunoreagentes para o diagnóstico laboratorial da raiva, existem algumas limitações, como por exemplo, a obtenção das proteínas de interesse parcialmente purificadas, pelo fato de que essa metodologia separa as proteínas segundo seus pesos moleculares, dificultando a obtenção de antígenos puros, uma vez que a replicação viral é realizada em cultura de células e estas quando lisadas para liberação das proteínas virais liberam também altas concentrações de proteínas celulares. Além disso, a metodologia requer o uso de equipamentos de alto custo e necessita de muito tempo operacional (Caporale et al., 2009).

Atualmente, diferentes técnicas de cromatografia têm sido empregadas na purificação de vírus da raiva e subunidades, principalmente na purificação de vírus extraídos de culturas celulares para uso na produção de vacinas, a qual tem sido realizada por cromatografia de troca iônica (Aaslestad, Wiktor, 1972; Frazatti-Gallina et al., 2004, Kumar et al., 2005) e na purificação da proteína N, expressa em células de insetos infectadas com baculovirus recombinantes, que pode ser realizada usando cromatografia de troca iônica (Préhaud et al., 1990) ou cromatografia de imunoafinidade (Dietzschold, 1996).

\subsection{Cromatografia}

A cromatografia é um dos métodos mais comuns de purificação de proteínas. Esta técnica consiste na passagem da amostra que contém a proteína de interesse, 
denominada fase móvel, por uma coluna, a fase estacionária, constituída para reter ou diminuir a velocidade da passagem da fase móvel, cuja função é separar a proteína de interesse dos outros constituintes da amostra. Dependendo da escolha da coluna, as proteínas podem ser separadas de acordo com a sua carga (cromatografia de troca iônica - CTI), sua hidrofobicidade (cromatografia de interação hidrofóbica - $\mathrm{CIH}$ ), seu tamanho (cromatografia em gel filtração - CGF) ou suas funções biológicas ou capacidade de se ligar a grupos químicos particulares (cromatografia de afinidade - CA) (Berg et al., 2002).

\subsubsection{Cromatografia de troca iônica - CTI}

A CTI é baseada na interação reversível entre a carga da proteína a ser purificada e a carga contrária do meio cromatográfico. Se a proteína possui carga positiva em pH 7.0 irá se ligar normalmente a uma coluna com carga negativa, ao passo que uma proteína carregada negativamente não. Uma proteína com carga positiva ligada a tal coluna pode então ser eluída, aumentando a concentração de cloreto de sódio ou outro sal no tampão de eluição, porque os íons de sódio irão competir com grupos carregados positivamente da proteína ligada à coluna. Proteínas que têm uma baixa densidade de carga líquida tenderão a emergir primeiro, seguidas por aquelas que têm uma maior densidade de carga. Proteínas positivamente carregadas (proteínas catiônicas) podem ser separadas em colunas de carga negativa. Inversamente, as proteínas carregadas negativamente (proteínas aniônicas) podem ser separadas por cromatografia em colunas carregadas positivamente (Berg et al., 2002).

\subsubsection{Cromatografia de interação hidrofóbica - $\mathrm{ClH}$}

A ClH baseia-se nas propriedades hidrofóbicas de algumas proteínas. As proteínas são submetidas à presença de elevada concentração de sulfato de amônio, o qual aumenta a entropia da água, aumentando, assim, as interações hidrofóbicas e também estabilizando as proteínas. Os domínios hidrofóbicos da proteína interagem com o ligante hidrofóbico da resina, sendo então eluidos por gradiente descendente de sal ou por gradiente ascendente de solvente orgânico (Berg et al., 2002). 


\subsubsection{Cromatografia em gel filtração - CGF}

A CGF separa as proteínas com base no seu tamanho. A coluna é constituída por uma matriz de pequenas esferas porosas empacotadas. Ao fazer passar a solução de proteínas pela matriz da coluna, as moléculas pequenas entram nos poros das esferas demorando a atravessá-los, enquanto que as de maior raio hidrodinâmico passam entre as esferas eluindo primeiro (Berg et al., 2002).

\subsubsection{Cromatrografia de afinidade}

A cromatografia de afinidade é definida como uma técnica cromatográfica líquida que utiliza interações biológicas para a separação e análises de analitos específicos dentro de uma amostra. Exemplos dessas interações incluem a ligação de uma enzima com o inibidor ou de um anticorpo com o antígeno. Tais processos de ligação são usados na cromatografia de afinidade, obtendo primeiro um agente de ligação, conhecido como "ligante de afinidade", que interage seletivamente com o analito, o produto de interesse, e então colocá-lo em um suporte sólido dentro de uma coluna (Hermanson et al., 1992). Uma vez que o ligante imobilizado foi preparado, isto pode ser usado para $o$ isolamento ou quantificação do analito. $O$ ligante imobilizado é o fator chave que determina o sucesso de qualquer método cromatográfico. A técnica de cromatografia de afinidade tem se tornado o método de separação de escolha em vários campos da biologia como nas ciências farmacêuticas, química clínica e biotecnologia (Hage, 1999).

$\mathrm{Na}$ cromatografia de afinidade de baixo desempenho (ou em coluna) o suporte normalmente é um gel não rígido de diâmetro grande como agarose, dextrana ou celulose. Esse método é usualmente utilizado para extração e prétratamento da amostra por ser um método relativamente fácil de padronizar e de baixo custo (Hermanson et al.,1992; Hage 1998a).

A cromatografia de afinidade de alta eficiência (HPAC) consiste na utilização de suportes de partículas rígidas de pequeno diâmetro, como sílica ou polímeros sintéticos capazes de suportar as taxas de fluxo e/ou a pressão características de sistemas de cromatografia líquida de alta eficiência (HPLC). O melhor fluxo e a estabilidade da pressão dos suportes de alto desempenho fazem o HPAC fácil de incorporar em sistemas instrumentais, o que por sua vez permite maior velocidade e precisão para a quantificação automatizada dos analitos (Larson, 1987). 
Para a detecção direta do analito por cromatografia de afinidade a amostra de interesse é injetada na coluna de afinidade, em condições nas quais o analito irá se ligar fortemente ao ligante imobilizado. Isto ocorre geralmente a um $\mathrm{pH}$ e força iônica que mimetizam o ambiente natural do ligante e do analito. Por causa da especificidade da interação do analito-ligante, outros solutos na amostra tendem a ter pouca ou nenhuma ligação com o ligante e rapidamente são lavados da coluna. Após esses solutos não retidos serem removidos, um tampão de eluição é aplicado para dissociar o analito retido; isto normalmente envolve mudança de $\mathrm{pH}$ ou da composição do tampão da fase móvel (para diminuir a força de interação do analitoligante) ou adição de um agente competidor na fase móvel (para deslocar o analito do ligante). Conforme o analito é eluido da coluna ele é detectado ou coletado para uso posterior. O resultado final é uma separação seletiva e de fácil execução. Esta é a característica que faz essa técnica ser tão atraente para a purificação de solutos ou para a quantificação de componentes de uma amostra (Hage, 1999).

Somando-se à simplicidade da técnica existem outras vantagens em se usar o modo de detecção direta de cromatografia de afinidade. Por exemplo, quando os sistemas de HPLC são aplicados nesses modos ocorre um aumento na precisão e na velocidade da purificação, ocorre uma redução na variação de um lote para outro da amostra a ser analisada (Hage, 1998a,b; Larson, 1987).

De todos os tipos de cromatografia de afinidade os que utilizam interações antígenos-anticorpos compõem o maior e mais diverso grupo de métodos de afinidade em testes clínicos. Isto é um resultado combinado da especificidade dos anticorpos e de uma facilidade relativa de produzi-los para uma variedade de analitos. O termo "cromatografia de imunoafinidade" (CIA) é usado para o método de cromatografia de afinidade que na fase estacionária consiste de um anticorpo relacionado a um antígeno (Hage, 1998b; Phillips, 1985).

A CIA baseia-se no reconhecimento de epítopos antigênicos por anticorpos específicos e consiste em geral nas seguintes etapas: obtenção da amostra contendo o produto de interesse, anticorpos antígenos-específicos para serem imobilizados em matriz apropriada (resina), eliminação de produtos indesejados e recuperação por meio de eluição do produto de interesse (de Frutos, Reginer,1993). 


\section{OBJETIVOS}

\section{$2.1 \quad$ Objetivo geral}

Estabelecer metodologia de purificação de ribonucleoproteínas do vírus da raiva, por meio de cromatografia de imunoafinidade, a partir de soros hiperimunes, com a finalidade de obter elevado grau de pureza das frações contendo essas proteínas e diminuir o tempo operacional do processo realizado por meio de ultracentrifugação em gradiente de Cloreto de Césio.

\subsection{Objetivos específicos}

- Obtenção de RNP a partir da infecção de células BHK-21 para imunização de animais e obtenção de soros hiperimunes;

- Purificação de IgG antirribonucleoproteínas para uso em cromatografia de imunoafinidade;

- Construção de coluna de imunoafinidade para purificação de RNP. 


\section{MATERIAL, ANIMAIS E MÉTODOS}

\subsection{Fluxograma de metodologias}

Estão apresentadas na figura 5 as principais etapas metodológicas utilizadas e descritas neste estudo.

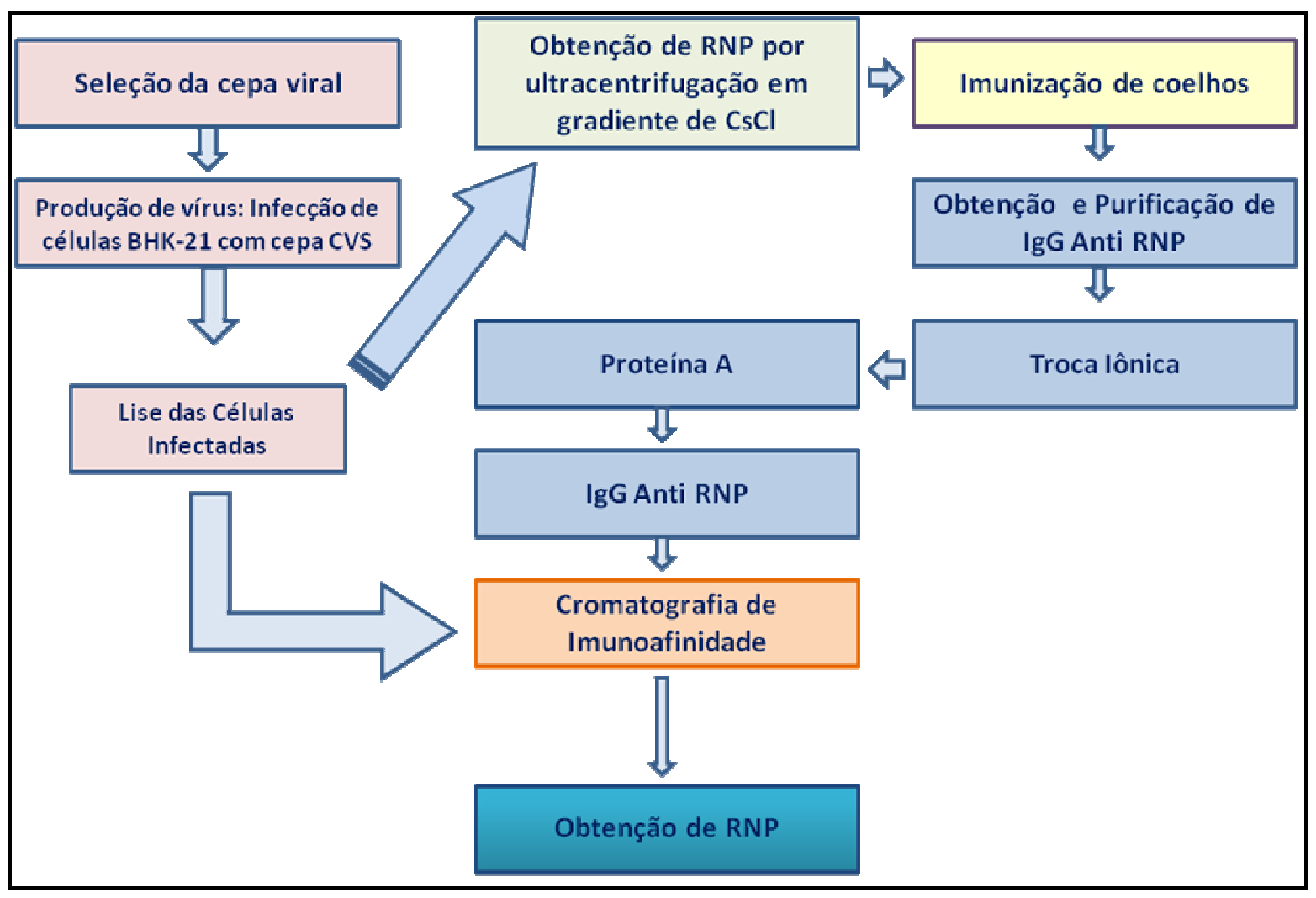

Figura 5. Fluxograma das etapas realizadas no desenvolvimento deste estudo.

\subsection{Linhagem celular}

Células BHK-21 (Baby Hamster Kidney - ATCC ${ }^{\circledR}$ CCL-10) foram utilizadas na produção de vírus para obtenção de RNP. Foram cultivadas em frascos de poliestireno para cultura celular, com meio essencial mínimo de Eagle (MEM), suplementado com $10 \%$ de soro fetal bovino (SFB), sendo mantidas a $37{ }^{\circ} \mathrm{C}$ até a formação de monocamada celular confluente. 


\subsection{Cepas Virais}

Inicialmente, as duas cepas de vírus fixo PV (Pasteur Virus) e CVS (Challenge Virus Standard), adaptadas à cultura celular, foram submetidas a uma seleção que definiu a cepa que seria utilizada na produção de vírus para obtenção das RNP.

\subsubsection{Seleção da cepa viral}

Para definir a cepa viral, PV ou CVS, mais adequada para uso no procedimento de produção de vírus para obtenção de RNP, foram colocadas seis lamínulas estéreis em placas para cultura celular de fundo chato, com 12 cavidades $\left(C^{C}\right.$ rning $\left.{ }^{\circledR}\right)$. Sobre três lamínulas adicionaram-se $100 \mu \mathrm{L}$ de suspensão de células BHK-21, em concentração de $5 \times 10^{5}$ células $/ \mathrm{mL}$ e $50 \mu \mathrm{L}$ de suspensão de vírus, cepa PV, diluído a 1:40, que corresponde a dose que infecta $100 \%$ das células (DICC100). O mesmo procedimento foi usado para as outras três lamínulas, adicionando-se a mesma concentração de células e suspensão de vírus CVS diluído a 1:100, uma DICC100. A cada cavidade foram acrescentados 2,5 mL de MEM, suplementado com $10 \%$ de SFB. A placa foi incubada a $37^{\circ} \mathrm{C}$ em atmosfera úmida com $5 \%$ de $\mathrm{CO}_{2}$ e as lamínulas com células BHK-21 infectadas com cada uma das cepas PV e CVS foram coletadas após os períodos de 12 e 24 horas de incubação. As lamínulas foram fixadas com acetona $80 \%$ gelada e, em seguida, foram submetidas ao teste de IFD para avaliação da infecção viral. A leitura foi feita em microscópio de fluorescência (Leica ${ }^{\circledR}$ ), filtro ultravioleta, lâmpada HBO-50, em aumento de 400x, observando-se a quantidade de células infectadas, a intensidade de fluorescência e a presença de inclusões intracitoplasmáticas características do vírus da raiva (Protocolo desenvolvido no Instituto Pasteur de São Paulo; Batista et al; 2009)

\subsubsection{Fotodocumentação}

Para demonstrar o padrão da infecção observado nas lamínulas com células BHK-21 infectadas com as cepas PV e CVS, coletadas nos períodos de 12 e 24 horas, foi realizada fotodocumentação em microscópio invertido de fluorescência, Nikon Eclipse TE2000-S, filtro ultravioleta, com lâmpada HBO-100, aumento de 200x. 


\subsection{Produção de vírus para obtenção de ribonucleoproteínas}

Com o objetivo de obter as RNP, foram realizadas as produções de dois lotes de vírus CVS em cultura de células BHK-21. Um dos lotes, utilizando protocolo padronizado no Instituto Pasteur de São Paulo, foi produzido por meio da propagação das partículas virais em sistema estático de frascos para cultura celular. E, para a obtenção de maior quantidade de células contendo as proteínas virais, outro lote de vírus foi produzido em sistema roller para cultura celular, utilizando protocolo para replicação viral, desenvolvido no Instituto Pasteur de São Paulo, modificado neste estudo quanto à etapa de lise celular.

\subsubsection{Replicação de vírus em sistema estático de cultura celular}

Foram utilizados 40 frascos de poliestireno para cultura celular, com capacidade para crescimento celular de $225 \mathrm{~cm}^{2}$ (figura 6A). A suspensão viral da cepa CVS, foi utilizada na diluição 1:100, uma DICC100, e as células BHK-21, após serem dissociadas por ação de tripsina, foram usadas na concentração $5 \times 10^{5}$ células $/ \mathrm{mL}$.

Foram adicionados $9 \mathrm{~mL}$ de suspensão de células em cada frasco e $9 \mathrm{~mL}$ de suspensão viral diluída previamente, completando-se o volume com $72 \mathrm{~mL}$ de MEM, contendo $10 \%$ de SFB. Os frascos foram mantidos por 48 horas a $34{ }^{\circ} \mathrm{C}$ e após esse período, o sobrenadante de cada frasco foi desprezado e a monocamada celular foi lavada com $40 \mathrm{~mL}$ de tampão PBS $0,01 \mathrm{~mol} / \mathrm{L} \mathrm{pH} \mathrm{7,0} \mathrm{estéril.} \mathrm{A} \mathrm{superfície} \mathrm{com} \mathrm{a}$ monocamada celular foi raspada com raspadores (cell scraper $32 \mathrm{~cm}-\mathrm{Nunc}^{\circledR}$ ) para a individualização das células (figura $6 \mathrm{~B}$ ), as quais foram ressuspendidas com tampão NT 0,5 mol/L pH 7.6 estéril e gelado e centrifugadas 2 vezes por 10 minutos a $900 \mathrm{~g} \mathrm{e} 4{ }^{\circ} \mathrm{C}$ (figura 6C) (Dietzschold, 1996).

A lise das células foi realizada, adicionando-se $5 \mathrm{~mL}$ de água (Milli- $\mathrm{Q}^{\circledR}$ ) estéril, gelada, contendo $60 \mu \mathrm{L}$ de Aprotinina (1000 unidades inibidoras de calicreína $\mathrm{KIU} /$ Sigma $^{\circledR}$ ), para cada $2 \mathrm{~mL}$ de conteúdo celular em tubos com capacidade de 50 $\mathrm{mL}$ (figura 6D) (Dietzschold,1996), permanecendo por 1 hora a $4{ }^{\circ} \mathrm{C}$. A lise foi intensificada com agitação manual dos tubos.

Após este período, realizou-se centrifugação a $1000 \mathrm{~g} \mathrm{e} 4{ }^{\circ} \mathrm{C}$ por 20 minutos. O sobrenadante foi recolhido e o procedimento de lise celular descrito anteriormente 
foi repetido duas vezes. Ao final, o volume total do sobrenadante foi coletado e centrifugado por 15 minutos, a $12000 \mathrm{~g} \mathrm{e} 4{ }^{\circ} \mathrm{C}$ (Hitachi, rotor CP28S).
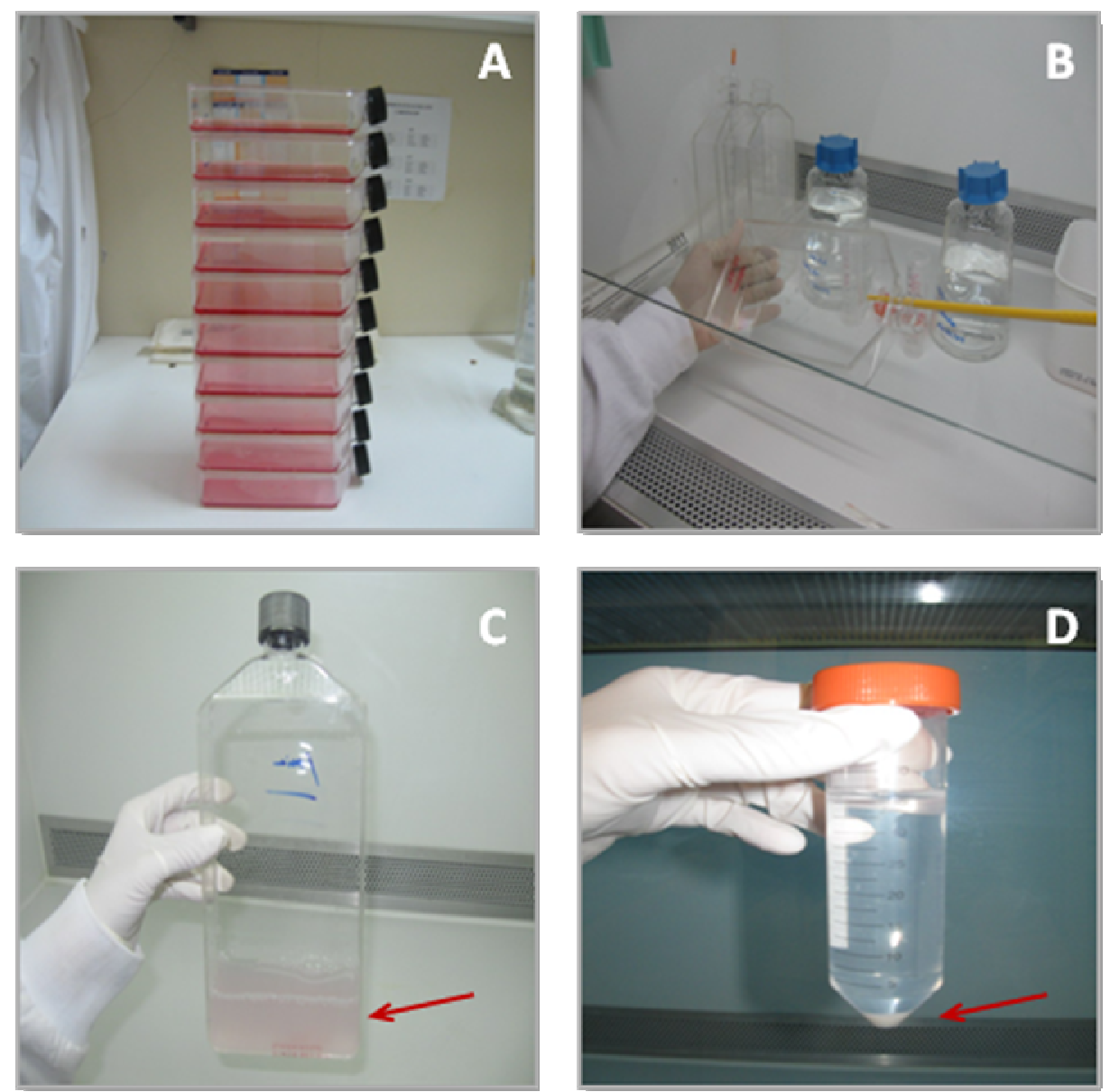

Figura 6. Etapas de replicação e purificação de RNP em sistema estático. A - Replicação da cepa CVS em sistema estático de cultura celular; B - Dissociação das células BHK-21 infectadas com a cepa CVS; C Sobrenadante contendo as células, após dissociação; D - Precipitado de células, após centrifugação

\subsubsection{Replicação de vírus em sistema roller de cultura celular}

Foram utilizadas 10 garrafas para sistema roller de superfície expandida com capacidade para crescimento celular de $1700 \mathrm{~cm}^{2}$ (Corning ${ }^{\circledR}$ ), (figura 7). A cepa CVS e as células BHK-21 foram usadas nas mesmas condições descritas no item 3.3.1. A cada garrafa foram adicionados $68 \mathrm{~mL}$ de suspensão de células e $68 \mathrm{~mL}$ de suspensão viral, completando-se o volume com $544 \mathrm{~mL}$ de MEM, contendo 10\% de SFB. As garrafas foram mantidas 48 horas a $34{ }^{\circ} \mathrm{C}$, com velocidade de rotação de $1.5 \mathrm{rpm}$ no sistema roller.

O sobrenadante de cada garrafa foi desprezado e a monocamada celular foi lavada com $40 \mathrm{~mL}$ de tampão PBS $0.01 \mathrm{~mol} / \mathrm{L}$ pH 7.0 estéril. O tampão PBS foi 
desprezado e posteriormente, as garrafas foram mantidas por 24 horas, em temperatura de $-20{ }^{\circ} \mathrm{C}$, para que ocorresse a criofratura das células. Após esse período, as garrafas foram retiradas do freezer para a recuperação das células adicionando-se $10 \mathrm{~mL}$ de tampão NT 0,5 mol/L pH 7.6 estéril, gelado e contendo 60 $\mu \mathrm{L}$ de Aprotinina (1000 unidades inibidoras de Calicreína - KIU/Sigma ${ }^{\circledR}$ ).

O sobrenadante de cada garrafa, contendo as células criofraturadas, foi coletado e ao final da coleta de todas as garrafas, os sobrenadantes foram reunidos e distribuídos em tubos com capacidade para $50 \mathrm{~mL}$ e centrifugados por 15 minutos a $12000 \mathrm{~g} \mathrm{e} 4{ }^{\circ} \mathrm{C}$ (Hitachi, rotor CP28S), para realizar a clarificação da solução, eliminando "debris" celulares.

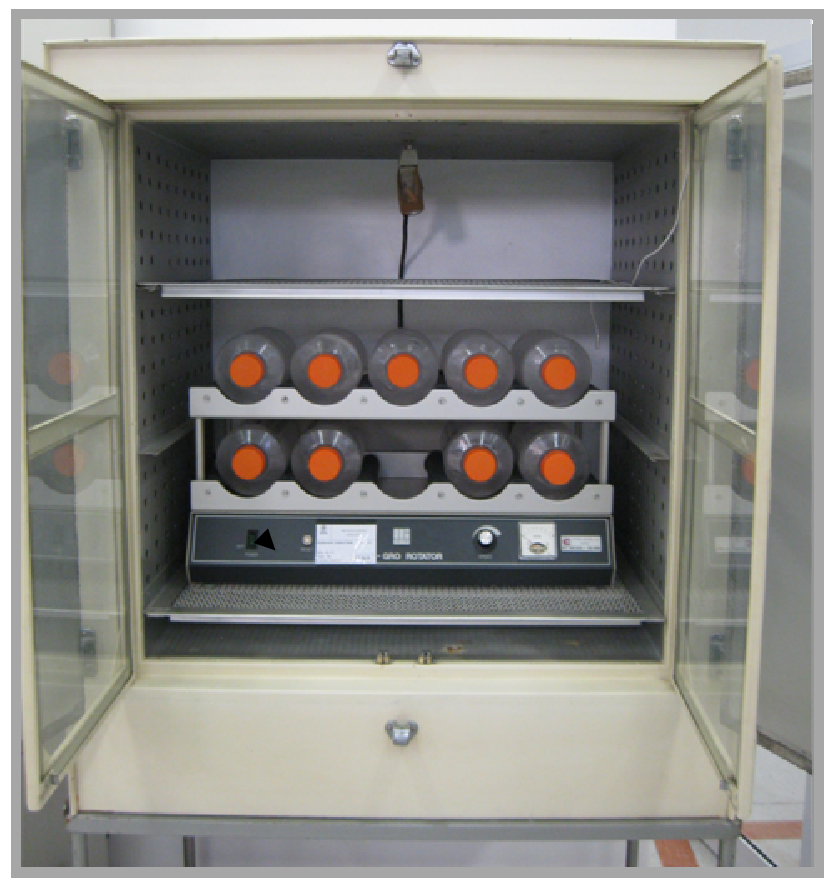

Figura 7. Replicação do vírus da raiva em sistema roller.

\subsection{Obtenção das ribonucleoproteínas por ultracentrifugação}

A obtenção das RNP dos sobrenadantes obtidos a partir de sistema estático e sistema roller foi realizada separadamente, pelo método de ultracentrifugação em gradiente de Cloreto de Césio (CsCl) (Dietzschold,1996; Caporale et al., 2009). Para cada $4,0 \mathrm{~mL}$ de sobrenadante contendo as RNP foram adicionados e dissolvidos por 24 horas a $4{ }^{\circ} \mathrm{C}, 2 \mathrm{~g}$ de $\mathrm{CsCl}$ em tubos de policarbonato com capacidade de $5 \mathrm{~mL}$. $\mathrm{O}$ volume final foi completado para $5 \mathrm{~mL}$ com tampão $\mathrm{NT}$ pH 7.6 e ultracentrifugado por 18 horas, a $150000 \mathrm{~g} \mathrm{e} 4{ }^{\circ} \mathrm{C}$ (Hitachi, rotor P55ST2). 
As bandas formadas foram coletadas com seringa e agulha estéreis. $O$ volume total obtido foi dialisado em membrana de celulose (Sigma ${ }^{\circledR}$ ) com tampão NT pH 7.6, por 24 horas a $4{ }^{\circ} \mathrm{C}$, com trocas sucessivas do tampão (Perrin et al., 1985).

\subsubsection{Determinação da concentração protéica das ribonucleoproteínas}

A dosagem da concentração das RNP foi realizada por espectrofotometria, pelo método de cálculo das absorvâncias 260/280 nm e os resultados foram expressos em mg/mL (Bollog, Edelstein, 1991).

\subsubsection{Confirmação da presença de ribonucleoproteínas}

A confirmação da presença das RNP foi realizada pelo método de eletroforese em gel de poliacrilamida com Dodecil Sulfato de Sódio (SDS-PAGE) a $12,5 \%$ e com empilhamento a 5\%, seguindo protocolo descrito por Laemmli (1970) e foi utilizado padrão de massas moleculares de proteínas conhecido (BIO-RAD ${ }^{\circledR}$ ). Procedeu-se a corrida fixando-se a corrente em $25 \mathrm{~mA}$ e em seguida, o gel foi corado com Coomassie blue 250-R.

\subsection{Animais}

\subsubsection{Considerações Éticas}

Devido à utilização de animais nos procedimentos realizados para obtenção de soro hiperimune contra proteínas do vírus da raiva, este projeto foi submetido à Comissão de Ética em Experimentação Animal (CEEA), do Instituto de Ciências Biomédicas da Universidade de São Paulo (ICB/USP), sendo aprovado em 22 de outubro de 2007 (Protocolo 051, fls. 45, livro 2).

\subsubsection{Descrição dos animais}

Dois coelhos denominados A e B, hígidos da raça Nova Zelândia, com peso de aproximadamente $3,0 \mathrm{~kg}$ e 4 meses de idade, foram imunizados com as RNP obtidas por ultracentrifugação em gradiente de Cloreto de Césio.

\subsection{Obtenção de soro hiperimune antirribonucleoproteínas}

As soluções contendo RNP, obtidas a partir dos dois protocolos de replicação e submetidas ao procedimento de ultracentrifugação em gradiente de $\mathrm{CsCl}$, foram 
unidas, após a determinação da concentração de proteínas e da confirmação da presença de RNP por meio de eletroforese, para realizar o fracionamento em alíquotas de $250 \mu \mathrm{g}$ de RNP, as quais foram mantidas a $-80{ }^{\circ} \mathrm{C}$ até o momento do uso.

Aos dois coelhos foi aplicado esquema de imunização, administrado por via subcutânea em multi-sítios, que consistiu em 4 doses de RNP, com intervalos de 7 dias e dois reforços com intervalos de 14 dias $(0,7,14,21,35$ e 49). As doses de 1 $\mathrm{mL}$ foram preparadas contendo $250 \mu \mathrm{g}$ de RNP, diluídas em $0,5 \mathrm{~mL}$ de tampão PBS $0.01 \mathrm{~mol} / \mathrm{L}, \mathrm{pH} 7.0$ e $0,5 \mathrm{~mL}$ de adjuvante completo de Freund na primeira dose e 0,5 $\mathrm{mL}$ de adjuvante incompleto de Freund para as doses subsequentes.

Sangrias de prova foram realizadas 10 dias após a última dose, por meio da veia auricular, coletando aproximadamente $0,3 \mathrm{~mL}$ de sangue, para realizar a avaliação dos níveis de anticorpos antiRNP.

Para realizar a sangria total, os coelhos A e B foram puncionados por via intracardíaca após terem sido devidamente anestesiados e sedados, obedecendo-se as normas éticas.

O sangue total dos coelhos A e B foram centrifugados, separadamente, por 20 minutos, a $1000 \mathrm{~g} \mathrm{e} 4{ }^{\circ} \mathrm{C}$, para obtenção dos soros hiperimunes, os quais foram armazenados em tubos com capacidade para $50 \mathrm{~mL}$ e armazenados a $-20{ }^{\circ} \mathrm{C}$, para posterior purificação dos anticorpos.

\subsubsection{Avaliação de anticorpos antirribonucleoproteínas}

A avaliação das amostras de soros dos coelhos imunizados com RNP foi realizada pelo teste de imunofluorescência indireta (IFI) (Goldwasser, Kissling, 1958). Foram feitas diluições seriadas dos soros (razão 2), de 1:100 a 1:2600 e foram aplicadas em lâminas com decalques de SNC de camundongo infectado com vírus da raiva e em lâminas com SNC de camundongo sadio como controle negativo. A reação foi revelada com uso do conjugado fluorescente comercial antiimunoglobulinas de coelhos $\left(\right.$ Sigma $\left.^{\circledR}\right)$, sendo que em seguida, as lâminas foram lidas em microscópio de fluorescência $\left(\right.$ Leica $\left.^{\circledR}\right)$, em aumento de $400 x$ e os títulos de anticorpos foram determinados pela definição da máxima diluição em que foi observada fluorescência intensa. Com base nessa observação foi selecionado, para ser submetido aos procedimentos de purificação de lgG, o soro do coelho que 
apresentou o maior título de anticorpos, sendo isto demonstrado pela realização da fotodocumentação da lâmina, contendo amostra do soro selecionado, em microscópio invertido de fluorescência Nikon Eclipse TE2000-S, filtro ultravioleta, com lâmpada HBO-100, aumento de 200x.

\subsection{Purificação dos anticorpos por cromatografia de troca iônica}

A purificação das $\lg G$ presentes no soro hiperimune, obtido pela imunização do coelho $A$, foi realizada por cromatografia em colunas de vidro graduadas, com 1,8 $\mathrm{cm}$ de diâmetro e $1,20 \mathrm{~m}$ de altura $\left(\right.$ Vidrolabor $\left.^{\circledR}\right)$. A resina utilizada para purificação foi de troca iônica (Sephadex QAE-50), sendo que para o preparo de cada coluna, a partir de $8 \mathrm{~g}$ de resina hidratada com tampão TED pH 7.0 obteve-se $80 \mathrm{~mL}$ de gel, os quais foram empacotados na coluna e submetidos a lavagem contínua com TED pH 7,0 por 24 horas (Joustra, Lundgren, 1969).

O soro foi descongelado e filtrado em membranas de $0,22 \mu \mathrm{m}$ (Millipore ${ }^{\circledR}$ ). Adicionou-se a $25 \mathrm{~mL}$ do soro o mesmo volume de tampão Etilenodiamina - TED (anexo), sendo então dialisado em membrana de celulose $25 \mathrm{~mm}\left(1.0^{\prime \prime}\right)$ (Sigma ${ }^{\circledR}$ ), utilizando-se o mesmo tampão por 24 horas. Após a diálise o soro foi aplicado à coluna e foram coletadas em tubos, frações de aproximadamente 2,0 mL. As frações foram lidas em espectrofotômetro pela absorvância a $280 \mathrm{~nm}$ e somente aquelas com densidade ótica (DO) $\geq 1,0$ foram selecionadas para a concentração das lgG.

\subsubsection{Concentração das imunoglobulinas}

As frações foram reunidas e ao volume total adicionou-se o mesmo volume de solução saturada de sulfato de amônio (anexo), em banho de gelo, sob agitação branda por 30 minutos. A solução, então, foi distribuída em tubos para centrífuga com capacidade de $50 \mathrm{~mL}$ e centrifugada por 30 minutos, a $1500 \mathrm{~g} \mathrm{e} 4{ }^{\circ} \mathrm{C}$. Após a centrifugação o sobrenadante dos tubos foi desprezado e o precipitado de lgG, de cada tubo, foi dissolvido em $1 \mathrm{~mL}$ de tampão PBS $0.01 \mathrm{~mol} / \mathrm{L} \mathrm{pH} \mathrm{7.0.}$

O volume total de IgG concentradas foi dialisado por 24 horas a $4{ }^{\circ} \mathrm{C}$, em tampão PBS $0.01 \mathrm{~mol} / \mathrm{L} \mathrm{pH} \mathrm{7.0,} \mathrm{com} \mathrm{trocas} \mathrm{sucessivas} \mathrm{até} \mathrm{a} \mathrm{completa} \mathrm{eliminação} \mathrm{do}$ sulfato de amônio da solução de $\operatorname{lgG}$, confirmada pela adição de reagente de Nessler ao tampão de diálise (anexo). Após esse período, a solução contendo lgG concentradas foi recolhida, armazenada em frasco estéril e mantida sob refrigeração. 
A determinação da concentração de proteínas da solução de lgG concentradas foi realizada por meio de leitura de absorvância a 260/280 nm, em espectrofotômetro (Bollog, Edelstein, 1991).

\subsection{Purificação dos anticorpos por cromatografia de afinidade}

Após o primeiro passo cromatográfico em resina de troca iônica e a concentração das lgG, as amostras foram submetidas à cromatografia de afinidade, em coluna de proteína A (HiTrap rProtein A FF - GE Healthcare ${ }^{\circledR}$ ) de 5,0 $\times 1,0 \mathrm{~cm}$, conectada a um sistema ÄKTA Purifier (GE Healthcare ${ }^{\circledR}$ ), previamente equilibrada com tampão PBS $0.01 \mathrm{~mol} / \mathrm{L} \mathrm{pH} \mathrm{7.0.} \mathrm{O} \mathrm{fluxo} \mathrm{aplicado} \mathrm{ao} \mathrm{sistema} \mathrm{foi} \mathrm{de} 1 \mathrm{~mL} / \mathrm{minuto}$ e a absorbância do eluato foi determinada à DO de $280 \mathrm{~nm}$. Foram realizados três ciclos de purificação, sendo injetados $3 \mathrm{ml}$ da lgG concentrada em cada corrida.

As imunoglobulinas adsorvidas à coluna foram eluídas, por meio de um pulso com tampão glicina 100 mM, pH 2,7 (anexo) e a absorvância do eluato foi determinada a $280 \mathrm{~nm}$.

As frações foram coletadas em alíquotas de 1,0 mL, em tubos contendo 100 $\mu \mathrm{L}$ de tampão Tris $1 \mathrm{~mol} / \mathrm{L} \mathrm{pH} 8.0$ (anexo). As frações compreendidas no pico foram reunidas e dialisadas em membrana de celulose $25 \mathrm{~mm}$ (1.0") (Sigma ${ }^{\circledR}$ ) com tampão PBS $0.01 \mathrm{~mol} / \mathrm{L}$ por 24 horas a $4{ }^{\circ} \mathrm{C}$. Após esse período, a solução dialisada foi recolhida, armazenada em frasco estéril e mantida sob refrigeração.

A determinação da concentração de proteínas da solução de lgG foi realizada por meio de leitura de absorvância a 260/280 nm, em espectrofotômetro (Bollog, Edelstein, 1991).

\subsubsection{Confirmação da pureza das imunoglobulinas por eletroforese}

Para verificar a pureza e confirmar a presença das imunoglobulinas na solução purificada, foi realizado o método de eletroforese em gel de poliacrilamida com Dodecil Sulfato de Sódio (SDS-PAGE) a 12,5\% e com empilhamento a 5\%, seguindo protocolo descrito por Laemmli (1970) e foi utilizado padrão de massas moleculares de proteínas conhecido $\left(\mathrm{BIO}-\mathrm{RAD}^{\circledR}\right)$. Foi realizada a corrida fixando-se a corrente em 25 mA e em seguida, o gel foi corado com Coomassie blue 250-R.

Foram aplicadas ao gel alíquotas das seguintes amostras: A - soro "bruto", B solução contendo lgG após ter sido submetida ao passo cromatográfico em coluna de troca iônica e concentração em sulfato de amônio, C - solução contendo lgG 
após ter sido submetida ao passo cromatográfico em coluna de afinidade e ter sido concentrada por precipitação com ácido Tricloroacético 50\%.

\subsection{Preparo da coluna para cromatografia de imunoafinidade}

Nesta etapa foi utilizado o protocolo recomendado pelo fabricante para 0 acoplamento do ligante (IgG anti RNP) à matriz CNBr- activated sepharose 4B (GE Healtcare $\left.{ }^{\circledR}\right)$. Para cada 1 grama de resina é recomendada a concentração de 5 a 10 mg de proteínas.

Para que ocorresse a hidratação da resina e ativação do brometo de cianogênio foram adicionados $200 \mathrm{~mL}$ de $\mathrm{HCl} 1 \mathrm{mM}$ (anexo) a 1 grama de resina, sendo este procedimento realizado adicionando-se à resina o volume de $50 \mathrm{~mL}$, mantendo-se a solução em repouso até a sedimentação do gel e em seguida aspirando-se o sobrenadante e hidratando-se novamente o gel com o mesmo volume, por mais 3 vezes.

Para realizar o acoplamento dos anticorpos ao gel, 2,5 $\mathrm{mL}$ de solução de lgG purificada, que correspondiam à concentração protéica de $9 \mathrm{mg}$, foram diluídos em 5 $\mathrm{mL}$ de tampão de ligação $\mathrm{NaHCO}_{3} 0.1 \mathrm{~mol} / \mathrm{L}, \mathrm{pH}$ 8.3, contendo $\mathrm{NaCl} 0.5 \mathrm{~mol} / \mathrm{L}$ (anexo), sendo em seguida misturado ao volume total do gel, permanecendo sob agitação branda por 1 hora à temperatura ambiente, após a sedimentação da resina uma alíquota do sobrenadante foi colhida e o restante desprezado.

Para a retirada do excesso de anticorpos não ligados ao gel foi realizada lavagem com $15 \mathrm{~mL}$ do mesmo tampão de ligação. O bloqueio de grupos remanescentes ativos do brometo de cianogênio foi realizado com tampão Tris-HCl $0.1 \mathrm{~mol} / \mathrm{L}, \mathrm{pH} 8.0$ (anexo) por 2 horas.

As duas alíquotas recolhidas antes e depois da ligação dos anticorpos ao gel foram submetidas à dosagem de proteínas por meio de leitura de absorbância a 260/280 nm, em espectrofotômetro (Bollog, Edelstein, 1991).

Após esse período o gel foi lavada em 3 ciclos, alternando o pH com $15 \mathrm{~mL}$ de tampão acetato $0.1 \mathrm{~mol} / \mathrm{L}$, $\mathrm{pH} 4.0$ - contendo $\mathrm{NaCl} 0.5 \mathrm{~mol} / \mathrm{L}$ (anexo), seguido por lavagem com $15 \mathrm{~mL}$ de tampão Tris- $\mathrm{HCl} 0.1 \mathrm{~mol} / \mathrm{L}$, $\mathrm{pH} 8.0$ - contendo $\mathrm{NaCl} 0.5$ $\mathrm{mol} / \mathrm{L}$ (anexo). 
Uma vez realizado o acoplamento dos anticorpos à resina, esta foi empacotada em uma coluna com capacidade para $900 \mu \mathrm{L}$ (figura 8) e armazenada a $4{ }^{\circ} \mathrm{C}$, para posterior utilização.

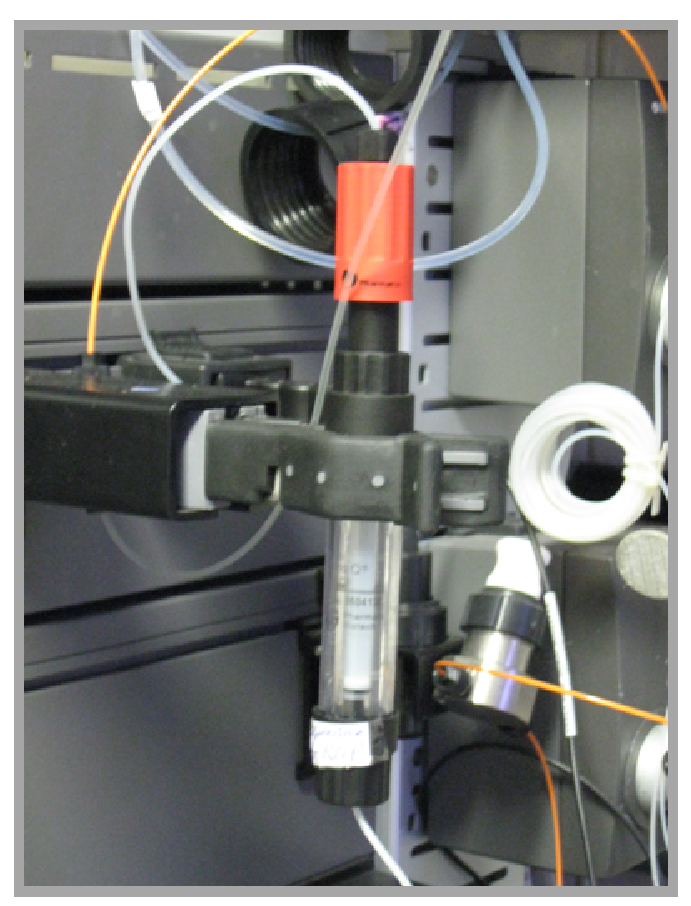

Figura 8. Coluna de imunoafinidade antiRNP - matriz CNBractivated sepharose $4 B$

\subsection{Obtenção de ribonucleoproteínas por cromatografia de imunoafinidade}

Duas amostras foram usadas para a obtenção de RNP por meio da coluna de cromatografia de imunoafinidade: suspensão protéica, obtida por meio da lise das células BHK-21 infectadas com a cepa CVS (lisado celular) e RNP obtidas pela ultracentrifugação em gradiente de $\mathrm{CsCl}$, que foi usada como controle da ligação específica das RNP.

Foram realizados dois ciclos para passagem da amostra de lisado celular, nos quais foram aplicados, respectivamente, os volumes de $0,5 \mathrm{~mL}$ e de $4 \mathrm{~mL}$ de amostra à coluna de imunoafinidade equilibrada com tampão PBS $0.01 \mathrm{~mol} / \mathrm{L} \mathrm{pH}$ 7.0, para proceder a cromatografia em sistema ÄKTA Purifier (figura 9), sob fluxo de $1 \mathrm{~mL} /$ minuto. A eluição das proteínas adsorvidas ao gel em cada ciclo foi realizada com aplicação de um pulso de tampão glicina 100 mM, pH 2.7 e a absorvância do eluato foi determinada a $280 \mathrm{~nm}$. 
Outro ciclo foi realizado para passagem da amostra de RNP obtida por ultracentrifugação em gradiente de $\mathrm{CsCl}$, sendo aplicado o volume de $2 \mathrm{~mL}$ da amostra à coluna, sob as mesmas condições descritas acima.

Nos três ciclos, as frações foram coletadas em alíquotas de 1,0 mL, em tubos contendo $100 \mu \mathrm{L}$ de tampão Tris $1 \mathrm{~mol} / \mathrm{L}, \mathrm{pH}$ 8.0. As frações de interesse, de cada ciclo, foram reunidas e dialisadas em membrana de celulose $\left(\right.$ Sigma $\left.{ }^{\circledR}\right)$ com tampão PBS $0.01 \mathrm{~mol} / \mathrm{L}$ por 24 horas a $4{ }^{\circ} \mathrm{C}$. Após esse período, as soluções foram recolhidas, armazenadas em frascos estéreis e mantidas sob refrigeração.

A determinação da concentração de proteínas, nas soluções de RNP obtidas em cada ciclo cromatográfico, foi realizada por espectrofotometria, com o método de cálculo das absorbâncias 260/280 nm e os resultados foram expressos em $\mathrm{mg} / \mathrm{mL}$ (Bollog, Edelstein, 1991).

A confirmação da presença das RNP foi realizada pelo método de eletroforese em gel de poliacrilamida, conforme foi descrito anteriormente no item 3.6.2.

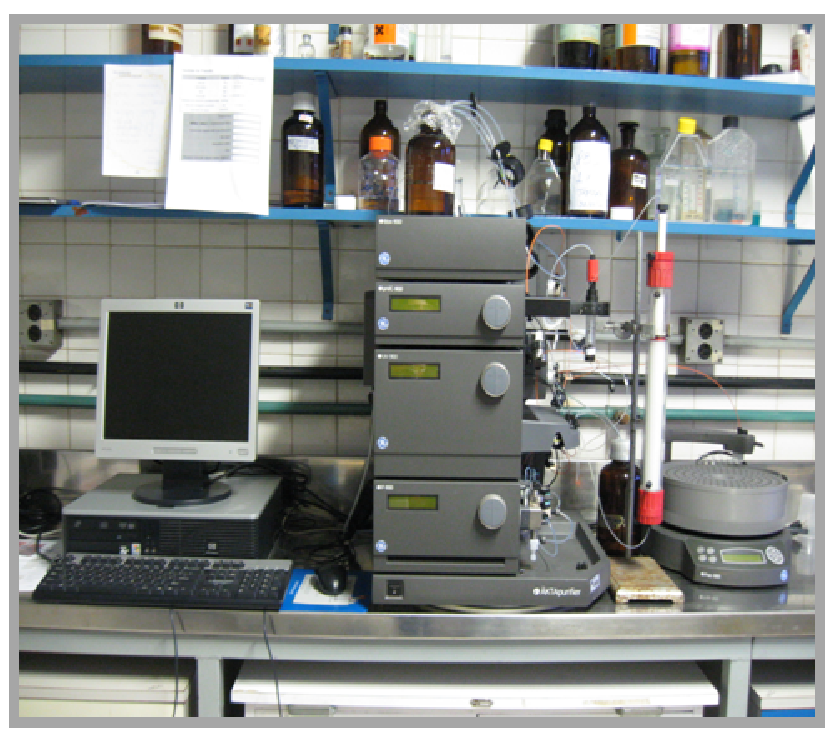

Figura 9. Cromatografia em sistema ÄKTA Purifier - obtenção de RNP 


\subsection{Seleção da cepa viral para obtenção de ribonucleoproteínas}

Estão demonstradas na figura 10 as células BHK-21 infectadas com a cepa PV e na figura 11 as células infectadas com a cepa CVS. Pode-se observar que tanto nas lamínulas colhidas após 12 horas de infecção (figuras 10A e 11A) como nas colhidas 24 horas após a infecção (figuras 10B e 11B) as células infectadas com a cepa CVS apresentaram maior grau de infecção, caracterizada pela quantidade de corpúsculos de inclusão intracitoplasmáticos e maior intensidade na fluorescência. Dessa maneira, a partir desta análise a cepa CVS foi selecionada para a infecção das células BHK-21, para posterior obtenção das RNP.

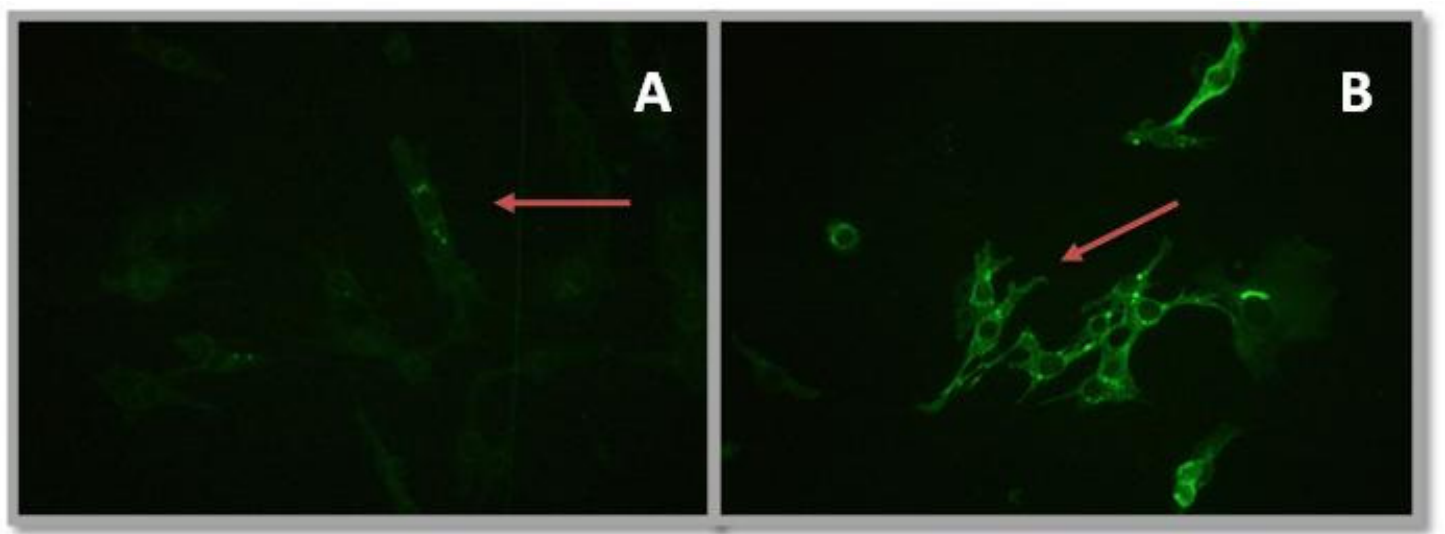

Figura 10. IFD em células BHK-21 infectadas com a cepa PV.

A. Infecção após 12 horas; B. Infecção após 24 horas

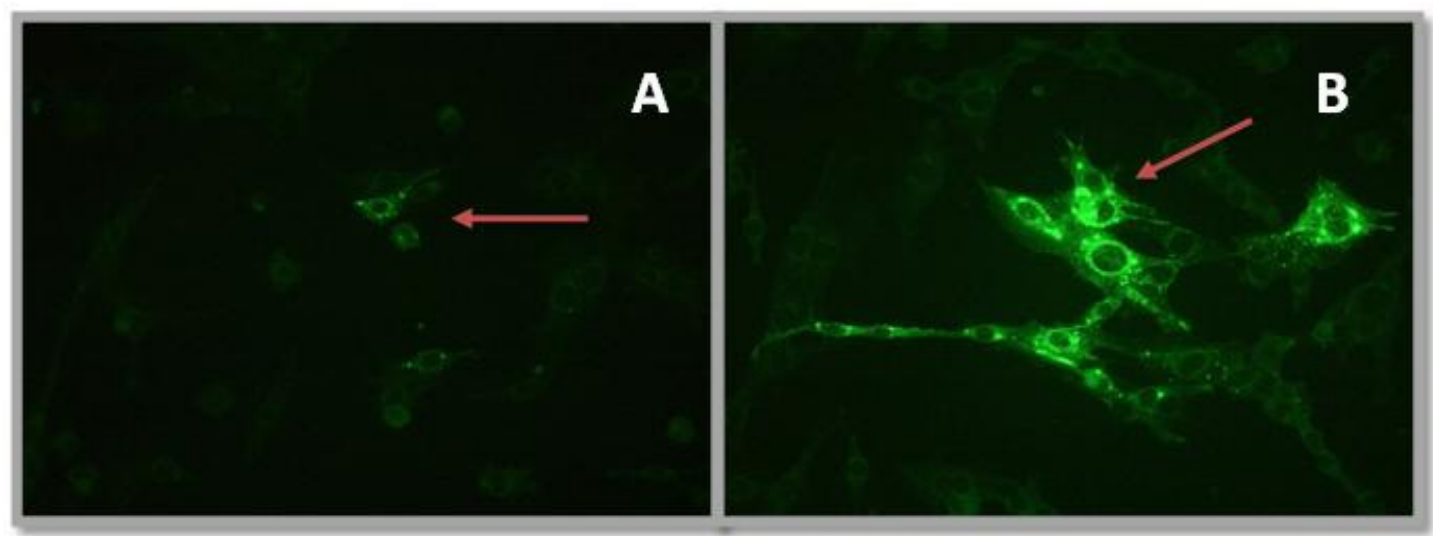

Figura 11. IFD em células BHK-21 infectadas com a cepa CVS.

A. Infecção após 12 horas; B. Infecção após 24 horas 


\subsection{Replicação de vírus em sistema estático de cultura celular}

Após a dissociação das células infectadas com a cepa CVS, mantidas por 48 horas a $37{ }^{\circ} \mathrm{C}$ em sistema estático de cultura celular, foi obtido o volume total de 250 $\mathrm{mL}$ de suspensão de células, a qual, depois da centrifugação, resultou no volume total de conteúdo celular de $6,5 \mathrm{~mL}$ e após a lise das células, o volume de solução contendo as RNP foi de $15 \mathrm{~mL}$.

\subsection{Replicação de vírus em sistema roller}

Depois da criofratura das células BHK-21 infectadas com CVS, mantidas em sistema roller, a suspensão de células obtida apresentou volume total de $100 \mathrm{~mL}$ de solução contendo as RNP.

\subsection{Obtenção das ribonucleoproteínas por meio de ultracentrifugação}

Após a ultracentrifugação foram recolhidas bandas de aproximadamente 0,5 $\mathrm{mL}$ de cada tubo e após a união das bandas recolhidas foram obtidos os volumes de 2,3 mL de RNP extraídas do sistema estático de cultura celular e 3,6 mL de RNP extraídas do sistema roller. A concentração de proteínas nessas soluções foi de 6,2 $\mathrm{mg} / \mathrm{mL}$ e $4,3 \mathrm{mg} / \mathrm{mL}$, respectivamente.

Na figura 12 está demonstrada a banda protéica formada após o processo de ultracentrifugação em gradiente de $\mathrm{CsCl}$, a qual foi obtida em todos os tubos de ambos os procedimentos realizados para obtenção das RNP.

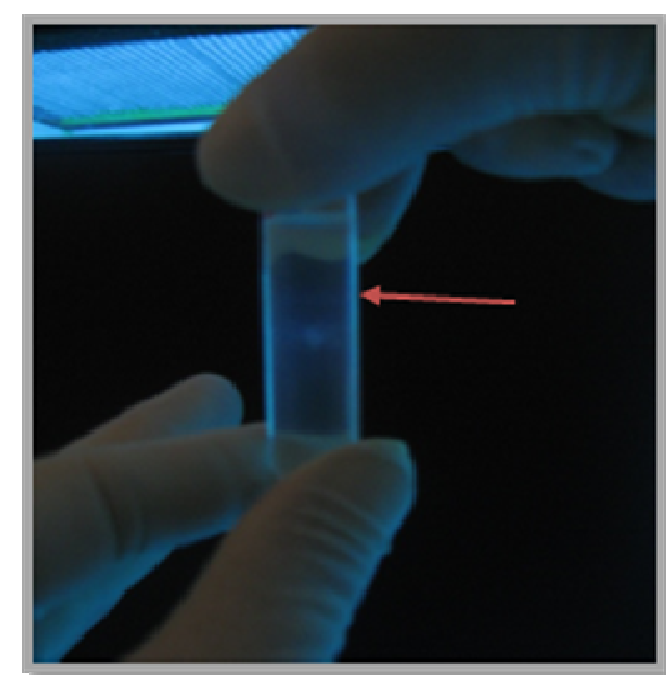

Figura 12. Gradiente de CsCl.

$$
\begin{aligned}
& \text { A seta indica a banda } \\
& \text { referente às RNP, após } \\
& \text { ultracentrifugação }
\end{aligned}
$$


$\mathrm{Na}$ figura 13, as amostras A e B referentes às RNP obtidas a partir das produções de vírus em sistema estático e sistema roller, respectivamente, demonstram a presença de bandas protéicas de massa molecular correspondente à nucleoproteína, que é característica de RNP, em concentrações semelhantes em ambas as amostras. Entretanto, outras bandas foram observadas, sugerindo a purificação parcial das amostras.

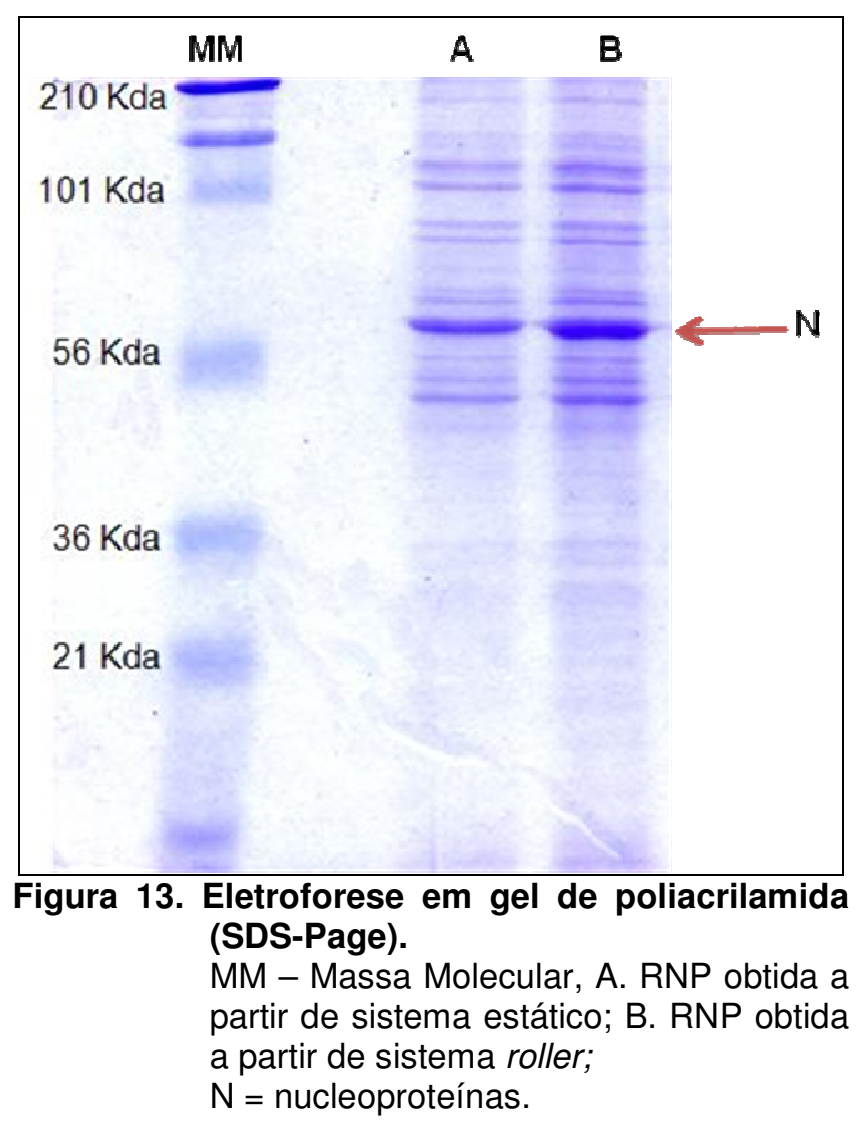

\subsection{Avaliação dos soros hiperimunes antirribonucleoproteínas}

A avaliação dos títulos dos soros dos coelhos por meio de IFI demonstrou que o soro do coelho $A$ apresentou fluorescência intensa até a diluição 1:2600 e o soro do coelho $B$ até a diluição 1:1600, conforme pode ser observado nas figuras 14 e 15, nas quais estão demonstradas as reações de fluorescência dessas diluições dos soros dos coelhos. Após essa análise o soro do coelho A foi selecionado para ser submetido às técnicas de purificação de anticorpos. 


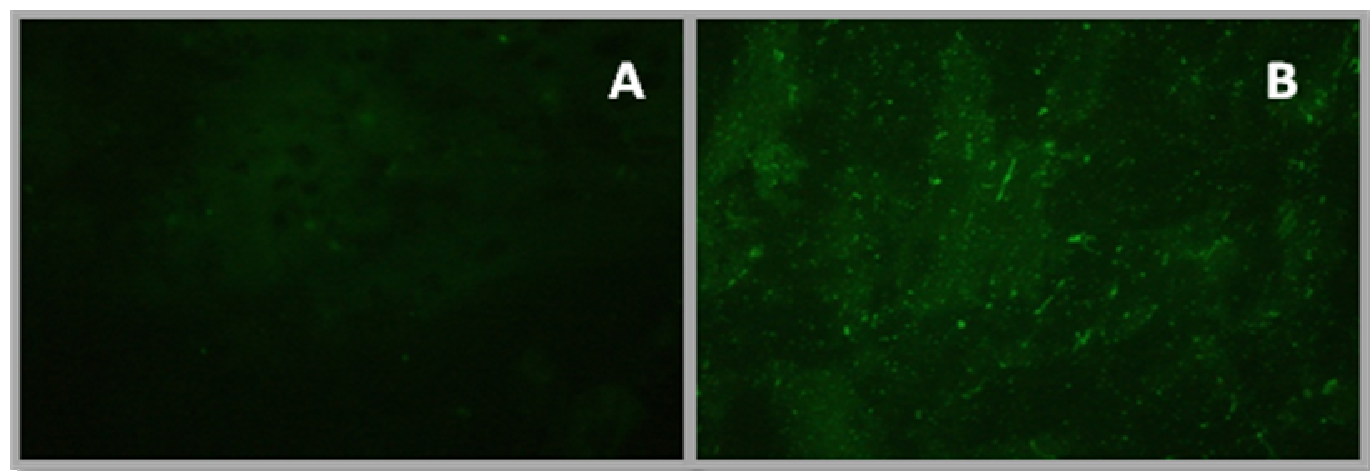

Figura 14. Imunofluorescência indireta, soro anti RNP do coelho $A$.

A. SNC de camundongo - controle negativo e B. SNC de camundongo infectado com cepa CVS - lâmina positiva, soro anti RNP diluição 1:2600.

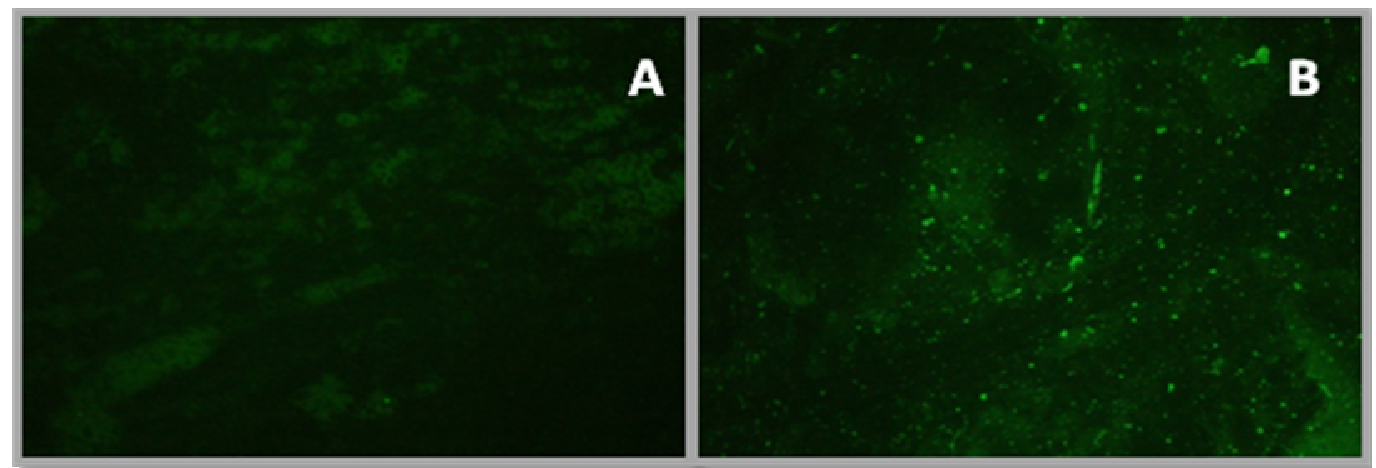

Figura 15. Imunofluorescência indireta, soro anti RNP do coelho B.

A. SNC de camundongo - controle negativo; B. SNC de camundongo infectado com cepa CVS - lâmina positiva, soro anti RNP diluição 1:1600.

\subsection{Purificação dos anticorpos por cromatografia de troca iônica}

Após o processo de purificação das lgG e leitura das DO das frações, 11 tubos foram selecionados e as soluções neles contidas foram reunidas totalizando o volume de $28,0 \mathrm{~mL}$, o qual apresentou a concentração protéica de $29,8 \mathrm{mg} / \mathrm{mL}$.

O volume, resultante do procedimento de concentração das IgG com sulfato de amônio, foi de $7,5 \mathrm{~mL}$, o qual apresentou concentração protéica de $32,7 \mathrm{mg} / \mathrm{mL}$.

A avaliação da presença e pureza das IgG na solução obtida, mostrou que embora tenham sido evidenciadas as bandas protéicas correspondentes à massa molecular das cadeias leve e pesada dos anticorpos, a solução apresentou bandas protéicas inespecíficas, conforme está demonstrado na figura 17.

\subsection{Purificação dos anticorpos por cromatografia de afinidade}

O fracionamento da amostra contendo as IgG, após a passagem em três ciclos de 3,0 $\mathrm{mL}$ para a purificação por cromatografia de afinidade, resultou no perfil 
cromatográfico com 2 picos majoritários, sendo que o primeiro representa as frações não adsorvidas e o segundo as frações eluídas contendo as IgG, que pode ser observado na figura 16. Esse perfil cromatográfico foi observado nos três ciclos realizados.

Após reunir as frações correspondentes ao pico de IgG dos três ciclos, o volume total foi de $19,0 \mathrm{~mL}$, o qual apresentou concentração protéica de $3,6 \mathrm{mg} / \mathrm{mL}$ e elevado grau de pureza, evidenciado pela presença de bandas protéicas correspondentes às cadeias leve e pesada das imunoglobulinas, conforme pode ser observado na figura 17.

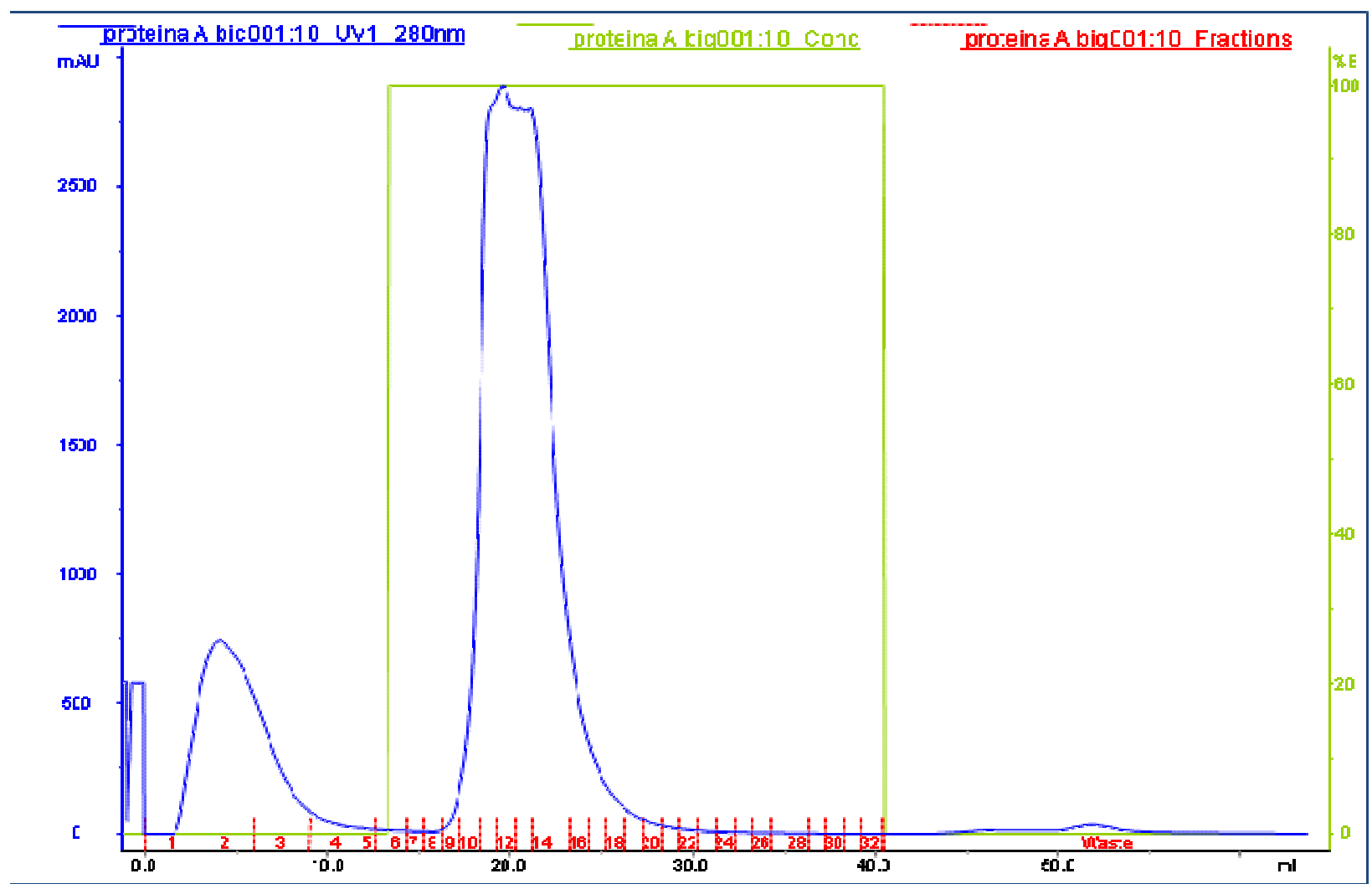

Figura 16. Perfil cromatográfico da purificação das imunoglobulinas (IgG) em coluna de afinidade Hi Trap rProtein A FF.

Pico de lgG correspondem às frações 10 a 17. Tampão A. PBS $0.01 \mathrm{~mol} / \mathrm{L} \mathrm{pH} 7.0$ e Tampão B. Glicina 100 mM pH 2.7. 


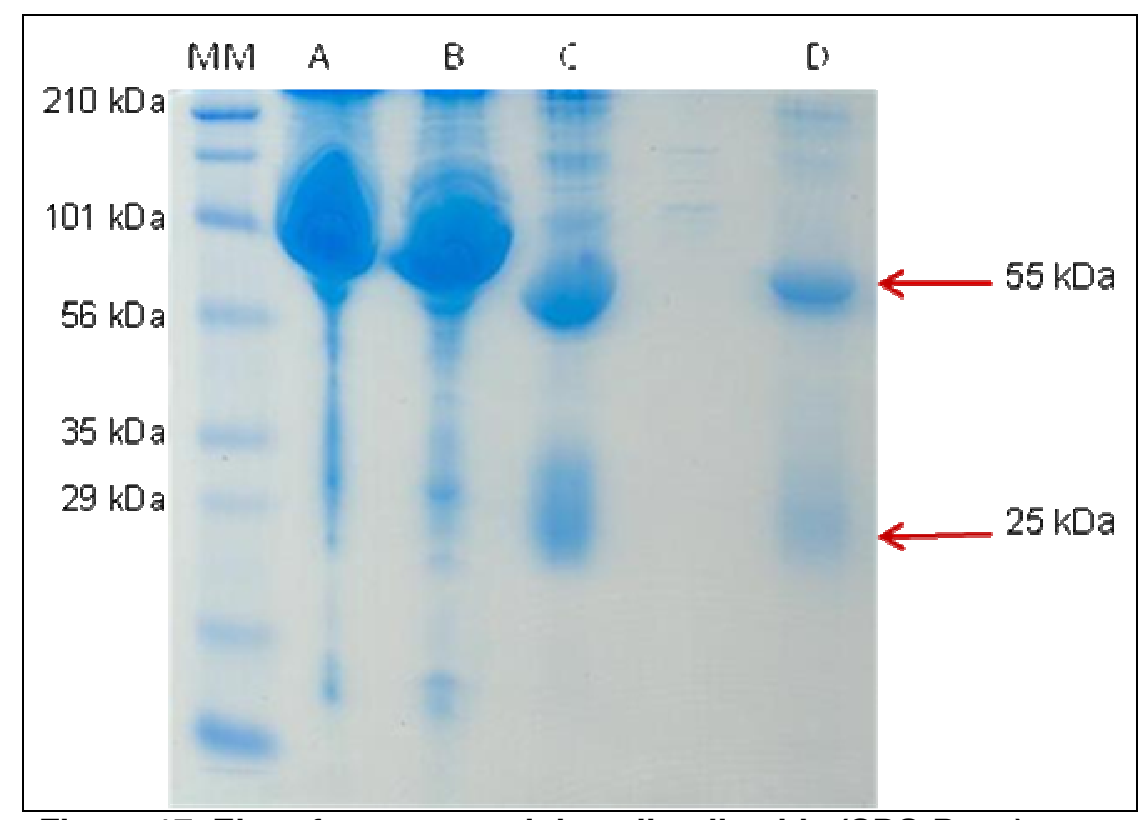

Figura 17. Eletroforese em gel de poliacrilamida (SDS-Page). MM. Massa Molecular, A. soro puro "bruto", B. solução contendo IgG a partir de um passo cromatográfico em coluna de troca iônica e precipitação em sulfato de amônio; C. amostra das frações do pico não retido; D. IgG purificada por cromatografia de afinidade (proteína A).

\subsection{Cromatografia de imunoafinidade para obtenção de ribonucleoproteínas}

A concentração protéica das alíquotas recolhidas antes e depois do procedimento realizado para acoplamento dos anticorpos ao gel foi de $1,13 \mathrm{mg} / \mathrm{mL}$ e $0,25 \mathrm{mg} / \mathrm{mL}$, respectivamente, indicando uma eficiência de $78 \%$ na reação de acoplamento. Após este resultado procedeu-se o empacotamento de uma coluna de $0,9 \mathrm{~mL}$ a partir do gel submetido ao processo de acoplamento dos anticorpos.

\subsection{Obtenção de ribonucleoproteínas por cromatografia de imunoafinidade}

Conforme pode ser observado na figura 18, o ciclo de purificação, no qual foi aplicada a amostra de $2 \mathrm{~mL}$ de RNP obtida por ultracentrifugação em gradiente de $\mathrm{CsCl}$, apresentou perfil cromatográfico com 2 picos majoritários, sendo que o primeiro representa as frações não adsorvidas e o segundo as frações eluídas contendo as RNP purificadas. Os volumes das duas frações compreendidas no segundo pico foram unidos, totalizando $2 \mathrm{~mL}$ de solução, os quais apresentaram concentração proteíca de $0,37 \mathrm{mg} / \mathrm{mL}$. A presença de RNP na solução foi confirmada pela observação de duas bandas protéicas, em gel de eletroforese, sendo uma delas correspondente à massa molecular da nucleoproteína (57 kDa) e 
outra banda inespecífica, indicando a purificação parcial das RNP (amostra G nas figuras 21 e 22).

Os dois ciclos realizados para a passagem de amostras de lisado celular contendo RNP, aplicando $0,5 \mathrm{~mL}$ no primeiro ciclo e $4 \mathrm{~mL}$ no segundo, em coluna de imunoafinidade anti RNP, resultaram em perfis cromatográficos, que podem ser observados nas figuras 19 e 20, respectivamente. No perfil cromatográfico de ambos os ciclos foram observados dois picos majoritários, sendo o primeiro correspondente às frações não adsorvidas e o segundo às frações contendo as RNP. A concentração protéica nas frações contendo RNP foram de $0,096 \mathrm{mg} / \mathrm{mL}$ para o primeiro ciclo e $0,275 \mathrm{mg} / \mathrm{mL}$ para o segundo ciclo e a confirmação da presença das RNP realizada por eletroforese, pode ser observada nas figuras 21 e 22, amostras A, nas quais foram evidenciadas três bandas sendo uma delas correspondente à massa molecular da nucleoproteína (57 kDa).

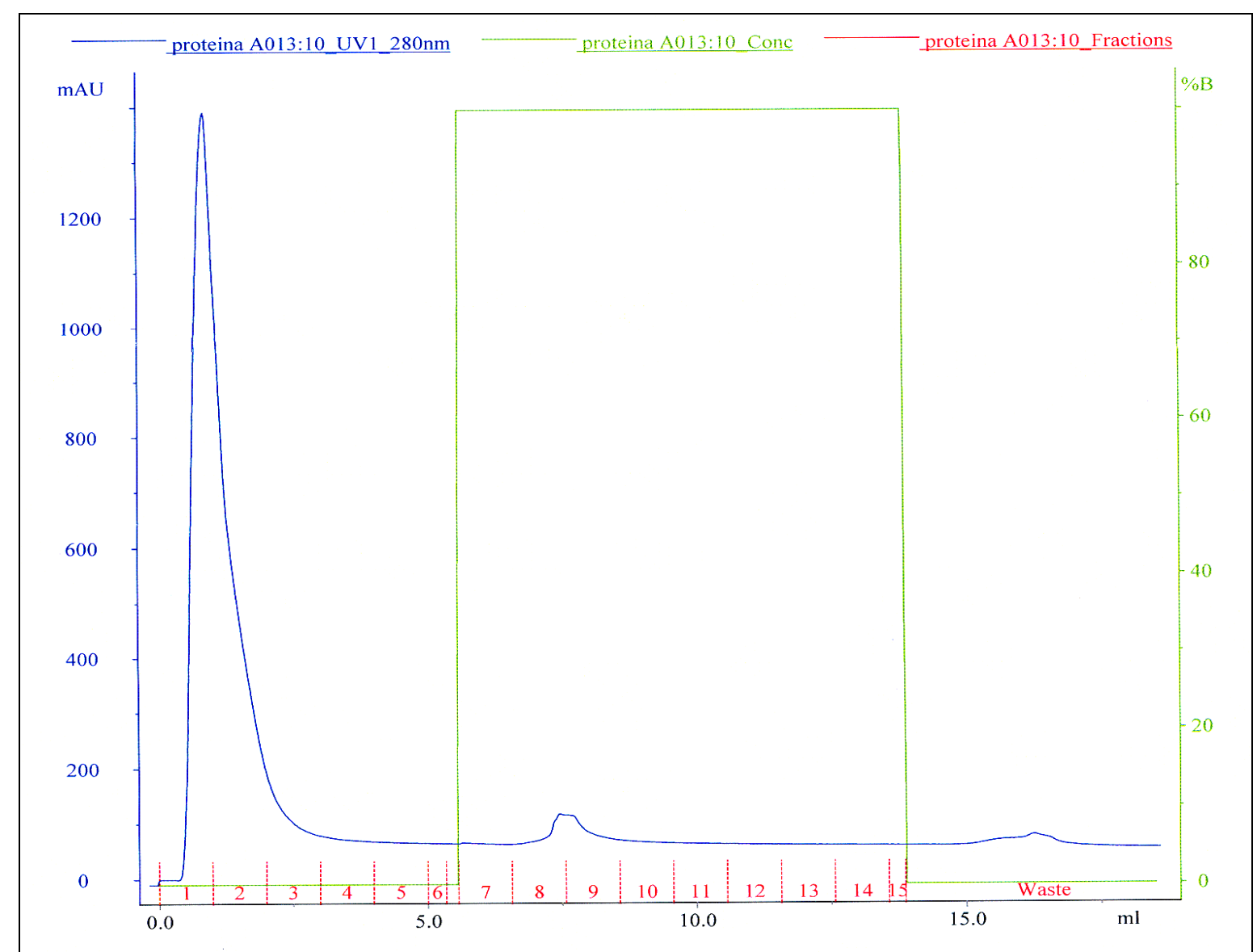

Figura 18. Perfil cromatográfico da purificação das RNP a partir da obtenção inicial por ultracentrifugação em gradiente de $\mathrm{CsCl}$.

Purificação em coluna de imunoafinidade $\mathrm{CNBr}$ - activated sepharose 4B antiRNP. Pico referente às RNP, frações 8 e 9. Tampão A. PBS $0.01 \mathrm{~mol} / \mathrm{L}$ pH 7,0 e Tampão B. Glicina $100 \mathrm{mM} \mathrm{pH} 2.7$. 


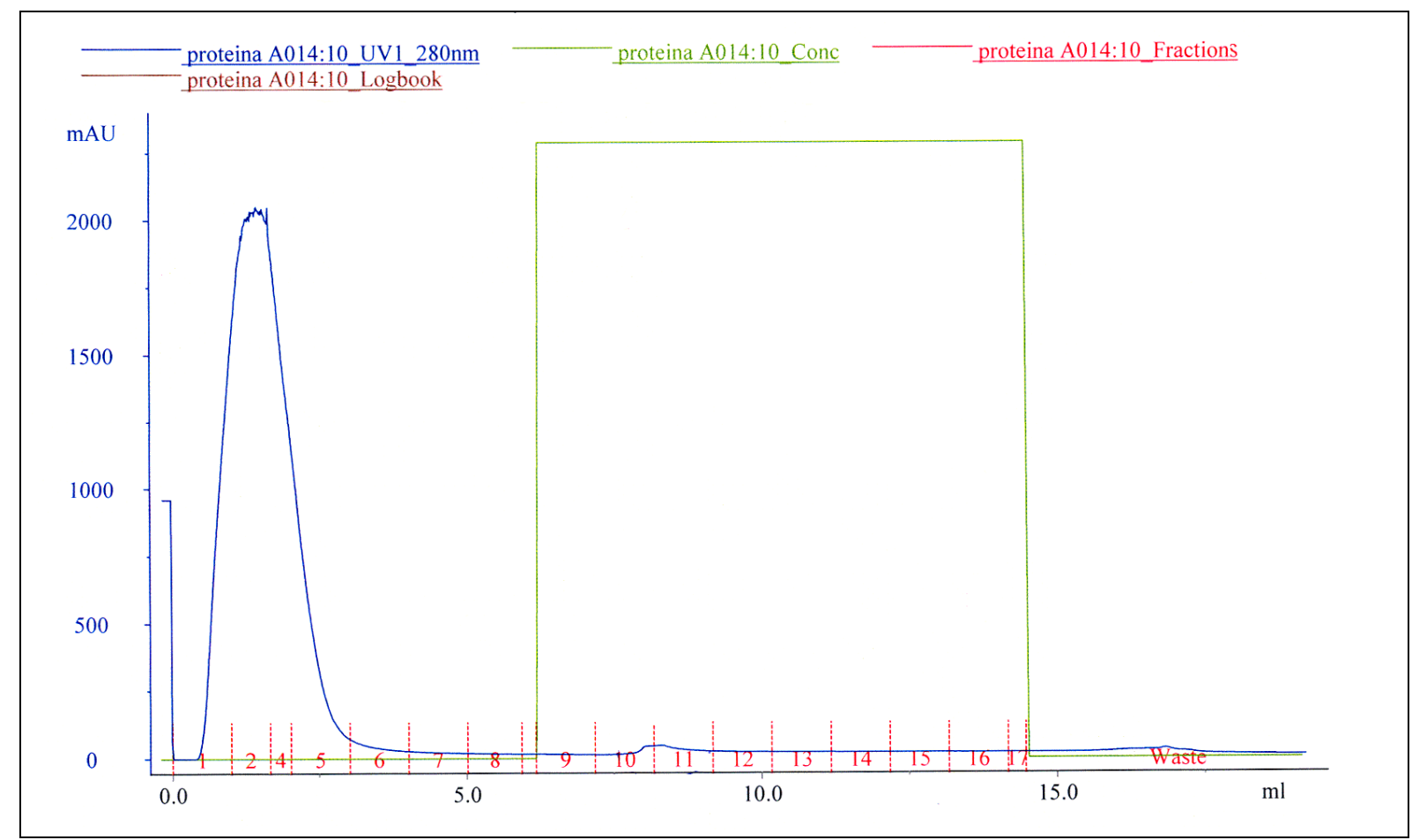

Figura 19. Perfil cromatográfico da purificação das RNP a partir de lisado celular.

Purificação em coluna de imunoafinidade $\mathrm{CNBr}$ - activated sepharose 4B antiRNP. Pico referente às RNP, frações 10 e 11.Tampão A. PBS $0.01 \mathrm{~mol} / \mathrm{L}$ pH 7.0 e Tampão B. Glicina $100 \mathrm{mM} \mathrm{pH} 2.7$.

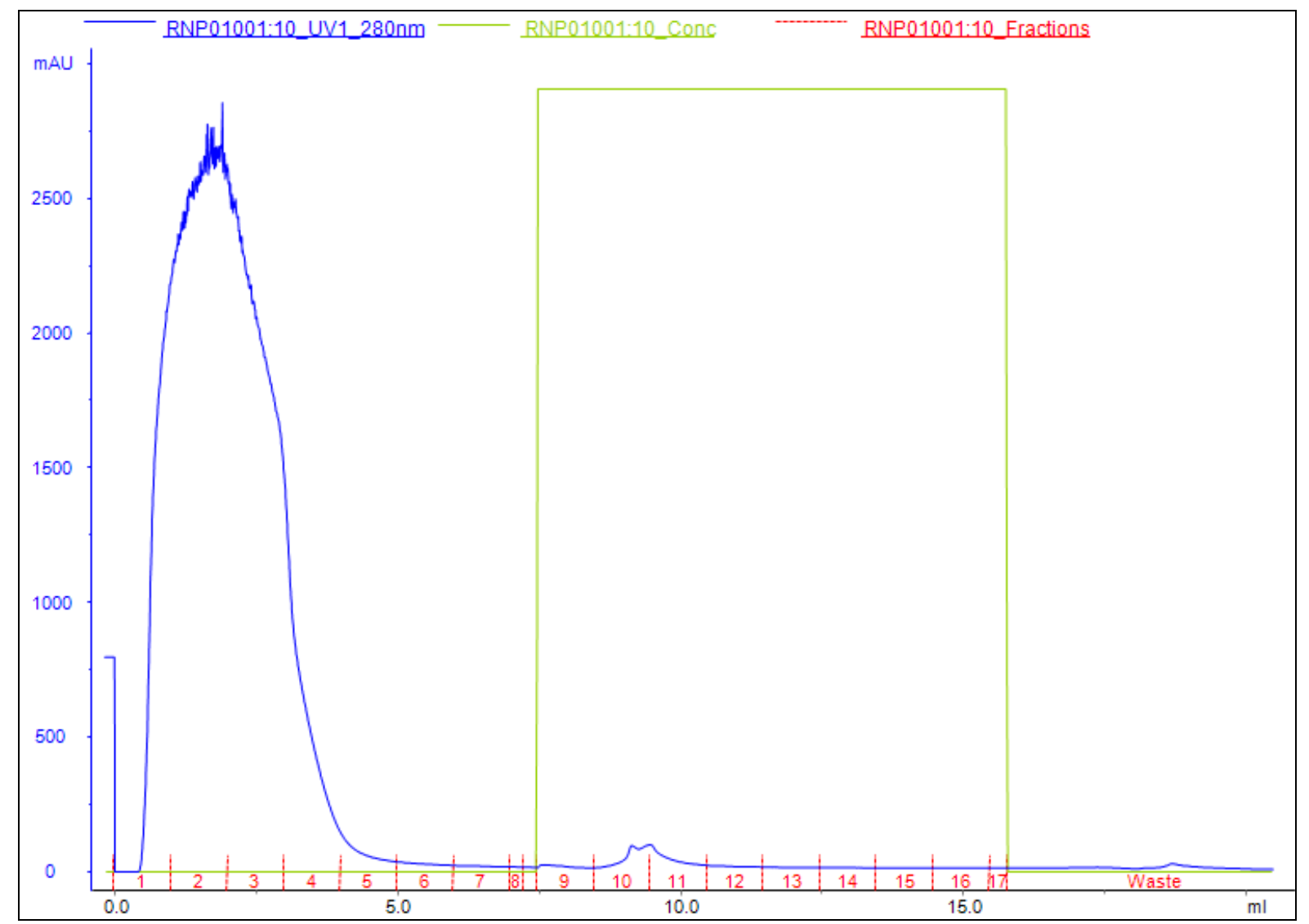

Figura 20. Perfil cromatográfico da purificação das RNP a partir de lisado celular

Purificação em coluna de imunoafinidade CNBr - activated sepharose $4 \mathrm{~B}$ antiRNP. Pico referente às RNP, frações 10 e 11. Tampão A. PBS $0.01 \mathrm{~mol} / \mathrm{L}$ pH 7.0 e Tampão B. Glicina $100 \mathrm{mM} \mathrm{pH}$ 2.7. 


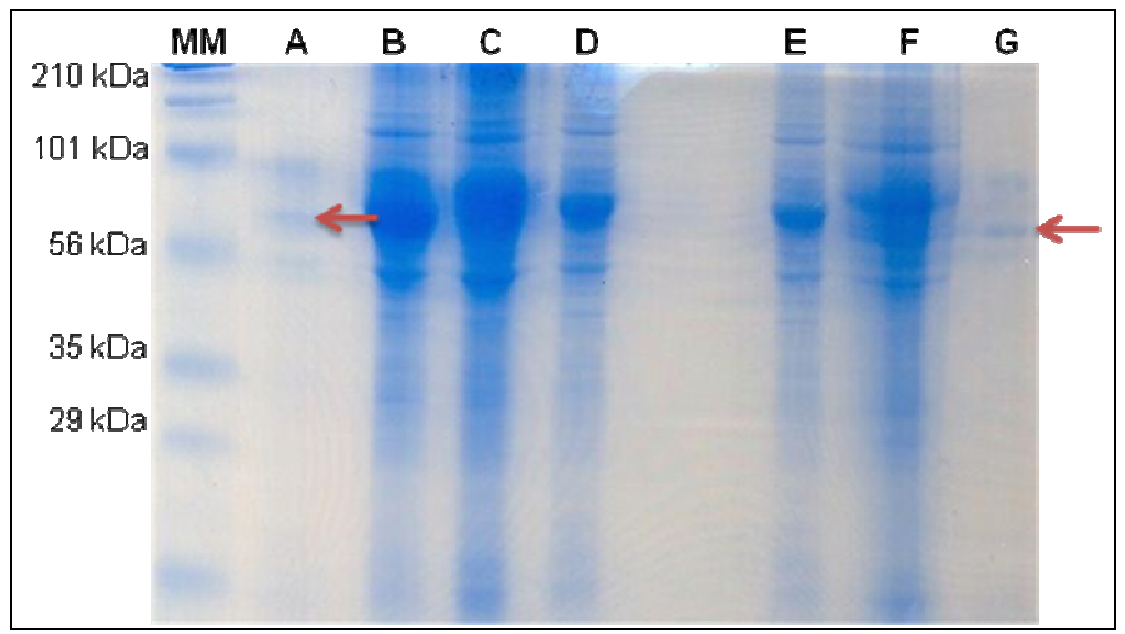

Figura 21. Amostra de RNP- lisado celular $0,5 \mathrm{~mL}$

Eletroforese em gel de poliacrilamida (SDS-Page); MM. Massa Molecular; A. amostra contendo RNP, após purificação em coluna de imunoafinidade antiRNP; B. amostra contendo RNP obtida por ultracentrifugação em $\mathrm{CsCl}$; C. amostra de lisado celular contendo as RNP antes da purificação em coluna de imunoafinidade antiRNP; D. amostra do pico correspondente às frações não adsorvidas, após purificação de $A ; E$. amostra do pico correspondente às frações não adsorvidas, após purificação de G; $F$. amostra contendo RNP a partir de ultracentrifugação em CsCl; G. purificação das RNP a partir da obtenção inicial por ultracentrifugação em gradiente de $\mathrm{CsCl}$ - purificação em coluna de imunoafinidade $\mathrm{CNBr}$ - activated sepharose 4B antiRNP, As setas indicam as nucleoproteínas. 


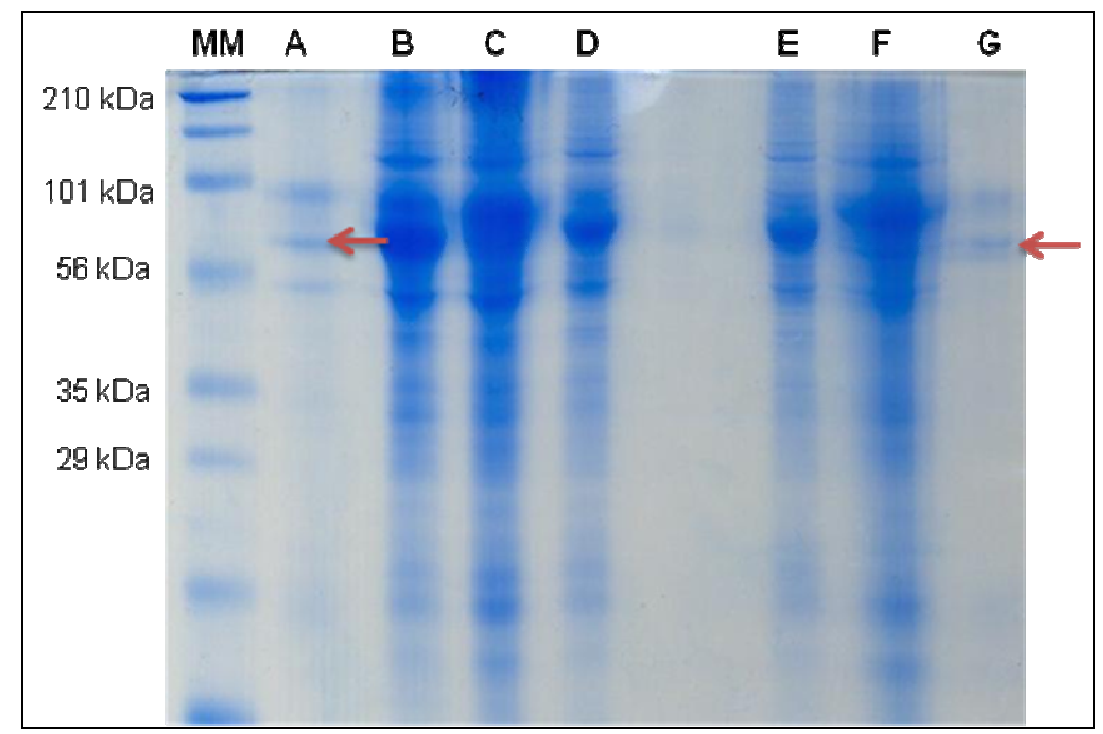

Figura 22. Amostra de RNP- lisado celular $4 \mathrm{~mL}$

Eletroforese em gel de poliacrilamida (SDS-Page); MM massa molecular, A. amostra contendo RNP, após purificação em coluna de imunoafinidade antiRNP; B. amostra contendo RNP a partir de ultracentrifugação em $\mathrm{CsCl}$; C. amostra de lisado celular contendo as RNP antes da purificação em coluna de imunoafinidade antiRNP; D. amostra do pico correspondente às frações de não retido, após purificação de A; E. amostra do pico correspondente às frações de não retido, após purificação de $G$; $F$. amostra contendo RNP a partir de ultracentrifugação em CsCl; G. purificação das RNP a partir da obtenção inicial por ultracentrifugação em gradiente de $\mathrm{CsCl}$ - purificação em coluna de imunoafinidade antiRNP. As setas indicam as nucleoproteínas. 


\section{DISCUSSÃo}

A obtenção de vírus da raiva ou suas subunidades tem sido fundamental para a realização de muitos métodos diagnósticos e produção de vacinas, e quanto maior o grau de pureza maior será a especificidade e potência para estes fins. Em 1972, Aaslestad e Wiktor realizaram diferentes métodos para concentração e purificação de vírus da raiva para produção de vacina e demonstraram que pelo método de concentração por ultrafiltração e purificação por cromatografia de troca iônica foram obtidos resultados bastante satisfatórios quanto à recuperação de altas concentrações de partículas virais e redução do nível de proteínas não virais, permitindo assim elevar a escala de produção.

Com o objetivo de construir uma coluna de imunoafinidade para a obtenção de subunidades do vírus da raiva (ribonucleoproteínas - RNP), neste estudo foram realizadas as seguintes etapas para avaliação da replicação das cepas CVS e PV em células BHK-21, replicação da cepa CVS em sistema estático e roller, concentração das RNP por meio de ultracentrifução em gradiente de $\mathrm{CsCl}$, imunização de coelhos para a obtenção de soro hiperimune anti RNP, concentração das IgG por solução saturada de sulfato de amônio, purificação das IgG pelos métodos de cromatografia de troca iônica e afinidade (proteína $A$ ), construção da coluna de imunoafinidade a partir do acoplamento das lgG à matriz $\mathrm{CNBr}$ - activated sepharose 4B, para obtenção de RNP diretamente de lisado celular. A seguir, os resultados obtidos em cada etapa são discutidos.

Foi realizada, inicialmente, uma avaliação da cinética de infecção das células BHK-21 com as cepas PV e CVS para o melhor aproveitamento da produção de RNP no período de 48 horas. Nas condições utilizadas para este protocolo, esse é o período em que ocorre intensa replicação das proteínas virais, sendo possível obtêlas por meio da lise das células. Após 12 horas a infecção das células já pode ser observada tanto para a cepa PV quanto para a cepa CVS, entretanto foi possível observar maior número de focos de infecção para a cepa CVS (figura 11), o que também foi observado após o período de 24 horas de infecção. Esse mesmo padrão de cinética já havia sido observado e descrito por Batista et al., em 2009, quando foram comparadas as cinéticas de replicação das mesmas cepas. Assim, o padrão 
de replicação da cepa CVS foi mais apropriado para realizar a infecção das células BHK-21 e após o período de 48 horas proceder a extração das proteínas virais.

Para garantir a obtenção de alta concentração de RNP, o quê foi necessário e teve implicações na execução de todas as etapas deste estudo até chegar à construção da coluna de imunoafinidade, foram realizados dois protocolos para infecção das células BHK-21 com a cepa CVS. O primeiro realizado em sistema estático, em frascos com superfície para o crescimento celular de $225 \mathrm{~cm}^{2}$ e o segundo realizado em sistema roller, em garrafas expandidas com superfície para o crescimento celular de $1700 \mathrm{~cm}^{2}$, o qual possibilitou o crescimento das células em uma superfície aproximadamente seis vezes maior do que a dos frascos utilizados em sistema estático permitindo, portanto, obter maior concentração de células infectadas.

Seguindo protocolos já estabelecidos para a extração das RNP (Dietzschold, 1996; Caporale et al., 2009), as células infectadas e cultivadas em sistema estático foram dissociadas com raspadores, ressuspendidas, lavadas 3 vezes com tampão e lisadas pela adição de água, entretanto para as células infectadas em sistema roller não foi possível utilizar o mesmo método, pois os frascos usados neste sistema foram garrafas expandidas, que apresentam em toda sua extensão sulcos para aumentar a superfície de crescimento celular, o que impossibilitou a dissociação com raspadores e recuperação das células, sendo então necessária uma mudança no método e realização direta de lise das células por criofratura.

Com esse procedimento foi possível eliminar quatro passos no processo de liberação das RNP, diminuindo a utilização de reagentes e reduzindo o tempo operacional em aproximadamente três horas e meia, além de ter resultado em maior volume de lisado celular contendo RNP, indicando um melhor rendimento no processo de lise por criofratura da solução proveniente do sistema roller, uma vez que o volume utilizado no protocolo de ultracentrifugação corresponde a um quinto do volume total de lisado celular, enquanto para a solução proveniente do sistema estático foi utilizado o volume total de lisado celular.

As concentrações protéicas encontradas nas soluções de RNP obtidas após a ultracentrifugação dos lisados celulares provenientes dos dois protocolos, utilizados para a replicação de vírus em células BHK-21, sistema estático e roller, foram consideradas satisfatórias e similares, permitindo a união das soluções e o 
fracionamento em 118 doses de $250 \mu \mathrm{g}$ de proteína. Assim, o rendimento foi superior ao necessário, em relação ao número de doses utilizadas nos esquemas de imunização realizados para obtenção de soros hiperimunes, destinados à purificação de imunoglobulinas.

O método de cromatografia por troca iônica foi inicialmente escolhido para purificação de anticorpos, por ser utilizado com sucesso para a obtenção de IgG, destinadas à produção de conjugado anti RNP no IP/SP, para uso em testes de imunofluorescência (Caporale et al., 2009). A aplicação deste método para purificação das IgG, a partir da amostra de soro hiperimune com o maior título de anticorpos anti RNP, resultou em uma solução de $7,5 \mathrm{~mL}$ com concentração protéica de $32.7 \mathrm{mg} / \mathrm{mL}$, sendo adequada para a realização do acoplamento ao gel de sepharose 4B, ativado com brometo de cianogênio, uma vez que a concentração de proteínas de ligante ( $\mathrm{lgG}$ ) recomendada pelo fabricante é de 5 a $10 \mathrm{mg} / \mathrm{mL}$ para $1 \mathrm{~g}$ de resina (Protocolo -GEhealthcare ${ }^{\circledR}$ ).

Quando uma amostra dessa solução de IgG purificada foi analisada por meio de eletroforese (figura $17 \mathrm{em} \mathrm{B}$ ), foi observada a presença de bandas difusas não sendo possível a identificação das cadeias leves e pesadas das lgG, indicando a necessidade de uma nova purificação, a qual foi realizada por cromatografia de afinidade ( proteína A), possibilitando a obtenção das IgG com maior grau de pureza, como está demonstrado na figura $17 \mathrm{em} \mathrm{D}$, com volume e concentração proteíca adequados para a realização da etapa de acoplamento á matriz.

Considerou-se que a metodologia utilizada para o acoplamento das IgG anti RNP à matriz foi satisfatória, quando foi observada a diminuição da concentração protéica na solução recolhida após o término do processo, o que indicou uma eficiência de $78 \%$ na reação de acoplamento. É importante ressaltar que o método de acoplamento do ligante à matriz foi realizado de forma randômica, ou seja, uma reação não sítio dirigida, pois a interação do anticorpo com a fase sólida é inespecífica, o que não permite a determinação da orientação do anticorpo imobilizado. A fração do anticorpo que permanecerá funcional em acoplamentos desse tipo não é previsível, portanto, há a possibilidade de que às regiões de ligação do anticorpo com o antígeno fiquem estéricamente escondidas (Bartolini, Ribela, 2005). 
Após o empacotamento da coluna foram realizados três ciclos de passagens, um com amostra controle de RNP, obtida a partir da ultracentrifugação em $\mathrm{CsCl}$ e duas, a partir de lisado celular. Observando-se o perfil de eluição das amostras nos cromatogramas das figuras 18,19 e 20, pode-se verificar que as três amostras resultaram em perfis cromatográficos semelhantes, porém com diferentes concentrações protéicas. Isto pode ter ocorrido em consequência dos diferentes volumes das amostras aplicadas à coluna em cada ciclo.

A presença das nucleoproteínas, demonstrada por eletroforese (figuras $21 \mathrm{em}$ A e 22 em A), nas frações de RNP recolhidas após purificação na coluna de imunoafinidade, indica que ocorreu o acoplamento adequado dos anticorpos anti RNP à matriz, com direcionamento favorável para a ligação das RNP contidas na fase móvel, embora sejam observadas, nas mesmas frações, duas bandas que não correspondem a massas moleculares de proteínas constituintes do ribonucleocapsídeo.

Isso pode ter ocorrido devido à presença de contaminantes na solução obtida por ultracentrifugação em gradiente de $\mathrm{CsCl}$ e utilizada para imunização de animais, levando à indução de anticorpos inespecíficos nos soros hiperimunes utilizados para a purificação de $\lg G$ usadas na reação de acoplamento, pois sabe-se que as RNP são um produto intracelular o que torna a purificação mais difícil em comparação a produtos extracelulares, pois demandam o rompimento das células, sendo, consequentemente, as proteínas alvo liberadas com todas as outras moléculas intracelulares, o que amplia a diversidade de contaminantes (Jr. Pessoa, Kilikian, 2006) e na ultracentrifugação as proteínas podem concentrar-se em várias faixas do gradiente de acordo com sua massa molar, forma e densidade (Moraes, Castilho, Bueno, 2005), assim proteínas da célula que apresentem coeficiente de sedimentação semelhante aos das RNP podem ter sido coletadas.

Para elevar o grau de especificidade da coluna de imunoafinidade é possível a obtenção de anticorpos antinucleoproteínas para o acoplamento à matriz $\mathrm{CNBr}$ activated sepharose 4B, utilizando-se o método de eletroforese em gel de poliacrilamida para a obtenção de bandas correspondentes às nucleoproteínas, as quais podem ser recortadas do gel e utilizadas para a imunização de animais. A poliacrilamida neste caso funciona como um adjuvante, intensificando a resposta imune (Harlow, Lane, 1988). Assim seria possível obter soros hiperimunes 
antinucleoproteínas, livres de contaminantes, permitindo a construção de uma coluna de imunoafinidade com alto grau de especificidade.

A metodologia de purificação de proteínas por cromatografia de imunoafinidade tem sido aplicada com sucesso em diversos estudos envolvendo diferentes microorganismos (Rodero, Jiménez, Cuéllar; 2002; Ongay et al., 2010; Peralta, et al., 2009), porém quanto à purificação do vírus da raiva, estudos mostram a aplicação bem sucedida de método de cromatografia de troca iônica (Aalestad, Wiktor, 1972; Kumar et al., 2005). No Brasil, Frazatti-Gallina et al. (2004), utilizaram para a produção de vacina antivírus da raiva, os métodos de filtração tangencial e cromatografia de troca iônica para concentrar e purificar o vírus, respectivamente, sendo demonstrada elevada imunogenicidade e proteção da vacina, quando foram testadas amostras de soros de indivíduos que receberam tratamentos em esquema de pós exposição (Costa et al., 2007).

$\mathrm{Na}$ purificação de proteínas do vírus da raiva a partir de células infectadas, vem sendo aplicadas metodologias de ultracentrifugação em gradiente de $\mathrm{CsCl}$ para ribonucleoproteínas (Compans, Choppin, 1967; Sokol, 1973) e em gradiente de sacarose para glicoproteínas (Perrin, Thibodeau, Sureau, 1985; Perrin, Portnoi, Sureau, 1982), e as proteínas purificadas empregadas na produção de imunoreagentes, como o conjugado fluorescente para raiva (Caporale et al., 2009), e para padronização e realização de técnicas imunoenzimáticas para diagnóstico de raiva (Perrin, Rollin, Sureau, 1986) e avaliação de potência de vacinas (Thraenhart, Ramakrishnan, 1989).

O estabelecimento do método de cromatografia de imunoafinidade demonstrou várias vantagens em relação a outras metodologias como: eficácia para a obtenção de RNP com baixo grau de contaminantes e tempo operacional reduzido para a obtenção de proteínas virais diretamente do lisado celular. Estes resultados estão de acordo com os observados por Dietzschold (1996), que demonstrou a aplicação eficaz de método de cromatografia de imunoafinidade para purificação da nucleoproteína do vírus da raiva, expressa em células de insetos infectadas com baculovirus recombinantes.

É importante ressaltar que o produto final obtido neste estudo, as RNP, tem aplicação imediata para a imunização de animais e obtenção de soros hiperimunes para produção de conjugado fluorescente atualmente produzido no IP/SP. 


\section{CONCLUSÃO}

A partir de protocolos eficientes para a replicação da cepa CVS em linhagem de células BHK-21 foi possível a obtenção de RNP para a imunização de animais. Os soros hiperimunes foram purificados por diferentes métodos cromatográficos 0 que permitiu a obtenção de $\lg G$ anti RNP com alto grau de pureza para a construção de uma coluna de imunoafinidade anti RNP, para que essas proteínas possam ser purificadas a partir de lisado celular.

Os resultados obtidos foram satisfatórios e indicam a possibilidade de elevar a escala de produção e purificação dessas proteínas, as quais são fundamentais para a produção de conjugado fluorescente anti RNP usado para revelar os testes diagnósticos para a pesquisa do vírus da raiva em amostras de sistema nervoso central de animais suspeitos, isolamento do vírus em cultura de células N2A e avaliação do título de anticorpos neutralizantes em amostras de soros de indivíduos vacinados, os quais somados chegam a 48.000 diagnósticos/ano realizados pelo IP/SP e pela rede de laboratórios credenciados para o diagnóstico da raiva no Brasil.

A possibilidade de utilização da metodologia cromatográfica desenvolvida neste estudo abre diversas perspectivas para a produção de imunoreagentes, padronização de exames diagnósticos e pesquisa da raiva. 


\section{REFERÊNCIAS*}

Aaslestad HG, Wiktor TJ. Recovery of protective activity in rabies virus vaccines concentrated and purified by four different methods. App Microbial. 1972;24(1):37-43.

Acha PN, Szyfres B. Zoonosis y enfermidades transmisibles comunes al hombre y a los animales. 3th ed. Washington: Organización Panamericana de la Salud; 2003. v.2. $425 p$.

Ameyama S, Toriumi H, Takahashi T, Shimura Y, Nakahara T, Honda Y, Mifune K, Uchiyama T, Kawai A. Monoclonal antibody 3-9-16 recognizes one of the two isoforms of rabies virus matrix protein that exposes its $\mathrm{N}$-terminus on the virion surface. Microbiol Immunol. 2003;47(9):639-651.

Atanasiu $\mathrm{P}$, Tsiang $\mathrm{H}$, Virat $\mathrm{J}$. Obtention D'lgG anti-nucléocapsides rabiques. Purification et conjugaison a la peroxydase ou a l'isothiocyanate de fluorescéine. Ann Microbiol. 1974;125 B: 85-98.

Baer GM. Rabies in nonhematophagous bats. In: Baer GM. The natural history of rabies. New York: Academic Press; 1975. v.2, 79-97.

Banerjee AK,Transcriptions and replication of rhabdoviruses. Microbiol Rev. 1987;51(1):66-87.

Banerjee AK, Chattopadhyay D. Structure and function of the RNA polymerase of vesicular stomatitis virus. Adv Virus Res. 1990;38:99-124.

Barik S, Rud EW, Luk D, Banerjee AK, Kang CY. Nucleotide sequence analysis of the $\mathrm{L}$ gene of vesicular stomatitis virus (New Jersey serotype): identification of conserved domains in $L$ proteins of nonsegmented negative-strand RNA viruses. Virology. 1990;175(1):332-337.

Bartolini P, Ribela MTCP. Cromatografia de imunoafinidade. In: Pessoa Jr P, Kirlikian BV. Editors. Purificação de Produtos Biotecnológicos. Rio de Janeiro: Manole; 2006. p. 248-260.

Batista AM, Cruz PS, Almeida E, Costa AEB, Scheffer KC, Chaves LB, Silva ACR, Caporale GMM. Infecção de células BHK-21 cultivadas em monocamadas estacionárias por cepas de vírus PV e CVS. BEPA. 2009;6(71):4-11.

Batista FR, Pereira CA, Mendonça RZ, Moraes AM. Formulation of a protein-free medium based on IPL-41 for the sustained growth of Drosophila melanogaster S2 cells. Cytotechnology. 2008;57(1):11-22.

\footnotetext{
* De acordo com:

International Committee of Medical Journal Editors. Uniform requirements for manuscripts submitted to Biomedical Journals: sample references. Available from: http//www.icmje.org[2007 May 22].
} 
Berg, JM, Tymoczko JL, Stryer L. Exploring proteins. In: Berg JM, Tymoczko JL, Stryer L. Ed. Biochemistry. 5th ed. New York: WH Freeman and Co; 2002. 1050p.

Bollog DM, Edelstein SJ. Protein Methods. 1st ed. New York: Wily-Liss inc; 1991. 230p.

Brasil. Ministério da Saúde do Brasil. Secretaria de Vigilância em Saúde/ [homepage on internet] Vigilância Epidemiológica. Raiva. Casos da doença no Brasil. Disponível em: http://portal.saude.gov.br/portal/arquivos/casos_conf_raiva.pdf.[maio 2010].

Brass DA. Rabies in bats. Natural history and public health implications. Connecticut: Livia Press; 1994. 335p.

Briggs D, Hanlon CA. World rabies day 7: focusing attention on a neglected disease. Vet. Rec. 2007;161(9):288-289.

Canadian Food and Inspection Service. Countries recognized as rabies free for domestic cats and dogs. Disponível em: http://www.inspection.gc.ca/english/anima/imp/petani/coupaye.shtml.[maio 2010].

Caporale GMM, Silva ACR, Peixoto ZMP, Chaves LB, Carrieri M., Vassão, RC. First production of fluorescent anti-ribonucleoproteins conjugate for diagnostic of rabies in Brazil. J Clin Lab Anal. 2009;23(1):7-13.

Carstens EB. Ratification vote on taxonomic proposals to the International Committee on Taxonomy of Viruses (2009). Arch Virol. 2010;155:133-146.

Chaves LB, Silva ACR, Caporale GMM, Scheffer KC, Waquim Neto SJ, Carrieri ML, Kotait I. Diagnóstico ante-mortem da raiva humana: anticorpos neutralizantes em soro e líquido cefaloraquidiano. Boletim Epidemiológico Paulista. 2007;4(41):8-12.

Childs JE, Real LA. Epidemiology. In: Jackson AC, Wunner WH. Ed. Rabies. San Diego: Academic Press; 2007. 123-199.

Clark HF. Rabies viruses increase in virulence when propagated in neuroblastoma cell culture. Science. 1978;199:1072-1075.

Coleman PG, Févre EM, Cleaveland S. Estimating the public health impact of rabies. Emerg Infect Dis. 2004;10(1):140-142.

Compans R, Choppin P. The length of the helical nucleocapsid of Newcastle disease virus. Virologica. 1967;33:344-346.

Constantine DG. Rabies transmission by non bite route. Public Health Service. 1962;77:287-289.

Costa WA, Cunha RS, Bolzan VL, Silva ACR, Caporale GMM, Chaves LB, Oselka GW, Junqueira DA, Panachão MRI, Dias RA, Takaoka NY. Immunogenicity and safety of a new Vero cell rabies vaccine produced using serum-free médium. Vaccine. 2007;25:8140-8145. 
De Frutos M, Regnier FE. Tandem chromatographic-immunological analyses. Anal Chem. 1993;65:17-25.

Dean DJ, Abelseth MK, Atanasiu P. The fluorescent antibody test. In: Meslin FX; Kaplan MM, Koprowski H. Ed. Laboratory techniques in rabies. 4th ed. Geneva: World Health Organization; 1996. 88-95.

Dean DJ, Abelseth MK. The fluorescent antibody test. In: Kaplan MM, Koprowski H. Ed. Laboratory techniques in rabies. 3rd edition. Geneva: World Health Organization; 1973. 73-84. (WHO Monograph Series, no 23).

Diaz AM, Arispe E, Brunel C, Cavandoli C, Dellepiane N, Miranda A. La tecnica de contraimunoeletroforesis para la determinación de anticuerpos antirrabicos. Bol Ofic Sanit Panamer; 1986;101:255-261.

Dietzschold B, Li J, Faber M, Schnell M. Concepts in the pathogenesis of rabies. Future Virol. 2008;3(5):481-490.

Dietzschold $B$. Techniques for the purification of rabies virus, its subunits and recombinant products. In: Meslin FX, Kaplan MM, Koprowski H. Ed. Laboratory techniques in rabies. 4th ed. Geneva: World Health Organization; 1996. 175-180.

Dodet B. Preventing the incurable: Asian rabies, experts advocate rabies control. Vaccine.2006;24(6):3045-3049.

Ertl HC, Dietzschold B, Gore M, Otvos Jr L, Larson JK, Wunner WH, Kpprowski H. Induction of rabies virus-specific T-helper cells by synthetic peptides that carry dominant T-helper cell epitopes of the viral ribonucleoprotein. J. Virol. 1989;63(7):2885-2892.

Fauquet CM, Mayo MA, Maniloff J, Desselberger U, Ball LA. Virus taxonomy. In: Eighth Report of the International Committee on Taxonomy of Viruses. San Diego, CA: Academic press; 2005. 630-634.

Favoretto SR, Carrieri ML, Tino MS, Zanetti CR, Pereira OAC. Simplified fluorescence inhibition microtest for titration of rabies neutralizing antibodies. Rev Inst Med trop. São Paulo.1993; 35:171-175.

Fooks AR. The challenge of new and emerging lyssaviruses. Expert. Rev. Vaccines. $2004 ; 3(4): 333-336$.

Fooks AR, Brookes SM, Johnson N, McElhinney LM, Hutson AM. European bat lyssaviruses: an emerging zoonosis. Epidem Infect. 2003;131(3):1029-1039.

Frazatti-Gallina NM, Mourão-Fuches RM, Paoli RL, Silva MLN, Miyaki C, Valentini EJG, Raw I, Higashi, HG. Vero-cell rabies vaccine produced using serum-free medium. Vaccine. 2004;23:511-517. 
Frazzati-Gallina NM, Paoli RL, Mourão-Fuches RM, Jorge SA, Pereira CA. Higher production of rabies vírus in serum-free médium cell cultures on microcarriers. J Biotechnol. 2001;92(1):67-72.

Galesi AL, Pereira, CA, Moraes AM. Culture of transgenic Drosophila melanogaster Schneider 2 cells in serum-free media based on TC100 basal medium. Biotechnol J. 2007;2(11):1399-1407.

Gaudin Y, Ruigrok RW, Knossow M, Flamand A. Low-pH conformational changes of rabies virus glycoprotein and their role in membrane fusion. J Virol. 1993; 67(3):1365-1372.

Gaudin Y, Ruigrok RW, Tuffereau C, Knossow M, Flamand A. Rabies virus glycoprotein is a trimer. Virology. 1992;187(2):627-632.

Gaudin Y, Tuffereau C, Durrer P, Flamand A, Ruigrok RW. Biological function of the low-pH, fusion-inactive conformation of rabies virus glycoprotein $(\mathrm{G})$ : $\mathrm{G}$ is transported in a fusion-inactive state-like conformation. J Virol. 1995;69(9):5528-5534.

Goldwasser RA, Kissling RE. Fluorescent antibody staining of street and fixed rabies virus antigens. Proc Soc Exp Biol Med. 1958;98:219-223.

Gosztonyi G. Reprodution of Lyssaviruses: ultraestructural composition of Lyssavirus and function aspects of pathogenesis. Curr Top Microbiol Immunol. 1994;187:43-68.

Hage DS. Affinity chromatography. In: Katz E, Eksteen, Shoenmakers P, Miller N. Ed. Handbook of HPLC. New York: Marcel Dekker; 1998a, 483-498.

Hage DS. A survey of recent advances in analytical applications of immunoaffinity chromatography. J Chromatogr. 1998b;71:3-28.

Hage, DS, Affinity Chromatography: A review of clinical applications, Clin Chem. 1999;45:593-615.

Harlow E, Lane D. Immunizations. In: Harlow E, Lane D. Antibodies: a laboratory manual. New York: Cold Spring Harbor Laboratory Press;1988. 55-138.

Hermanson GT, Mallia AK, Smith PK. Immobilized affinity ligand techniques. New York: Academic Press; 1992. 454p.

ICTV - International Committee on Taxonomy of Viruses. [homepage on internet]. USA: ICTV. Disponível em: http://www.ictvonline.org/virusTaxonomy.asp?version=2009. [2010 May 21].

Iseni F, Barge A, Baudin F, Blondel D, Ruigrok RW. Characterization of rabies virus nucleocapsids and recombinant nucleocapsid-like structures. J Gen Virol. 1998;79:2909-2019.

Jackson A. Pathogenesis. In: Jackson AC, Wunner WH. Ed. Rabies. San Diego: Academic Press; 2002. 246-282. 
Joustra $M$, Lundgren $H$. Preparation of freeze-dried, monomeric and immunochemically pure $\lg G$ by a rapid and reproducible chromatographic technique. In: Peeters H. Protides of the biological fluids. (Proceedings of the 17th colloquium.) Bruges, arrtchap; 1969. 511-515.

Kaplan G, Turner GS, Warrel D. Rabies: the facts. 2nd ed. Oxford; New York: Oxford University Press; 1986. 8-74. (Oxford Medical Publications).

Kaplan MM. Safety precautions in handling rabies virus. In: Meslin FX, Kaplan MM, Koprowski $\mathrm{H}$ (Ed.). Laboratory techniques in rabies. 4th ed. Geneva: World Health Organization; 1996.3-8.

King AA. Cell culture of rabies virus. In: Meslin FX; Kaplan MM, Koprowski H. (Ed.) Laboratory techniques in rabies. 4th ed. Geneva: World Health Organization; 1996.114-130.

Kissi B,Tordo N,Bourhy H. Genetic polymorphism in the rabies virus nucleoprotein gene. Virolog. 1995; 209(2):526-537.

Klingen Y, Conzelmann KK, Finke S. Double-labeled rabies virus: live tracking of enveloped virus transport. J Virol. 2008;82:237-245.

Köhler G, Milstein C. Continuous cultures of fused cells secreting antibody of predefined specificity. Nature. 1975;256:495-497.

Kotait I, Carrieri ML, Takaoka NY. Manual técnico do Instituto Pasteur. vol. 8. Raiva: Aspectos gerais e clínica. São Paulo: Instituto Pasteur, 2009. 49p.il.

Kumar AAP, Mani KR, Palaniappan C, Bhau LNR, Swaminathan K. Purification, potency and immunogenicity analysis of Vero cell culture-derived rabies vaccine: a comparative study of single-step column chromatography and zonal centrifuge purification. Microbes and Infect. 2005;7:1110-1116.

Laemmli UK. Cleavage of structural proteins during the assembly of the head of bacteriophage T4. Nature. 1970;227(5259):680-685.

Lafon M, Wiktor TJ. Antigenic sites on the ERA rabies virus nucleoprotein and nonstructural protein. J Gen Virol. 1985; 66:2125-2133.

Lafon M. Rabies virus receptors. J Neurovirol. 2005;11(1):82-87.

Larson PO. High performance liquid affinity chromatography. Meth Enzym. 1987;104:212-223.

Lépine P, Atanasiu P. Histopathological diagnosis. In: Meslin FX, Kaplan MM, Koprowski H. Laboratory techniques in rabies. 4th ed. Geneva: World Health Organization; 1996.66-79. 
Mattos CA, Mattos CC, Rupprecht CE. Rhabdoviruses. In: Knipe DM, Howley PM. FIELDS Virology. 4th ed. Philadelphia: Lippincott Willians e Wilkins; 2001.1245-1278.

Mebatsion T, Weiland F, Conzelmann KK. Matrix protein of rabies virus is responsible for the assembly and budding of bullet-shaped particles and interacts with the transmembrane spike glycoprotein G. J Virol. 1999;73(1):242-250.

Mebatsion T. Extensive attenuation of rabies virus by simultaneously modifying the dynein light chain binding site in the $P$ protein and replacing Arg333 in the $G$ protein. J Virol. 2001;75(23):11496-11502.

Meslin FX, Kaplan MM. An overview of laboratory techniques in the diagnosis and prevention of rabies and in rabies research. In: Meslin FX, Kaplan MM, Koprowski H. Ed. Laboratory techniques in rabies. 4th ed. Geneva: World Health Organization; Switzerland, 1996.9-27.

Meslin FX, Kaplan MM, Koprowski H. Ed. Laboratory techniques in rabies. 4th edition. Geneva: World Health Organization; 1996. 478 p.

Moore JC. Gel permeation chromatography. I. A new method for molecular weight distribution of high polymers. J Polym Sci. 1964,2:835-843.

Moraes AM, Castilho LR; Bueno SMA. Processos de Purificação dos Produtos. In: Moraes AM, Augusto EFP, Castilho LR. Tecnologia do Cultivo de Células Animais de Biofármacos a Terapia Gênica. 1ed. São Paulo: Roca, 2008;289-320

Ongay S, Lacunza I, Díez-Masa JC, Sanz J, de Frutos M. Development of a fast and simple immunichromatographic method to purify alpha 1-acid glycoprotein from serum for analysis of its isoforms by cappillary electrophoresis. Anal Chim Acta. 2010;663(2):206-212.

Peralta $\mathrm{RH}$, Espíndola NM, Pardini AX, Iha AH, Moura H, Barr JR, Vaz AJ, Peralta $\mathrm{JM}$. Taenia crassiceps cysticerci: Characterization of the 14-kDa glycoprotein with homologies to antigens from Taenia solium cysticerci. Exp Parasitol. 2010;124(3):295-300.

Perl DP, Good PF. The pathology of rabies in the central nervous system. In: Baer GM. The Natural History of Rabies. 2nd ed. Boca Ratón: CRC Press; 1991.164-188.

Perrin P, Rollin PE, Sureau P. A rapid rabies enzyme immunodiagnosis (RREID): a useful and simple technique for the routine diagnosis of rabies. J Biol Standard. 1986;14:217-222.

Perrin $\mathrm{P}$, Lafon M, Versmisse P. Aplication súne méthode immunoenzymatique au titrage des anticorps rabiques neutralisants en culture cellulaire. J Biol Standard. 1985;13:35-42.

Perrin, P, Thibodeau L, Sureau P. Rabies immunosome (sub-unit vaccine) structure and immunogenicity. Pre- and pos-exposure protection studies. Vaccine. 1985;3:325331. 
Perrin $\mathrm{P}$, Portnoi $\mathrm{D}$, Sureau $\mathrm{P}$. Etude de l'absorption de la p'nétration Du vírus rabique: interactions avec lês cellules BHK-21 et dês membranes atificielles. [Study of the absorption and penetration of rabies virus: interactions with BHK-21 cells and artificial membranes.] Ann de l'Institut Pasteur: Virology. 1982;133E:403-422.

Pessoa Jr. A, Kilikian BV. Introdução. In: Pessoa Jr. A, Kilikian BV. Purificação de Produtos Biotecnológicos. 1ed. São Paulo: Manole; 2005;1-5.

Phillips TM. High performance immunoaffinity chromatography. LC Magazine 1985;3:962-972.

Piza ASS; Chaves LB; Zanetti CR. An ELISA suitable for detection of rabies virus antibodies in serum samples from human vaccinated whitt either cell culture vaccine or suckling mouse brain vaccine. Rev. Med. Trop. 1999;41:39-43.

Plotkin SA. Rabies, Clin Infect Dis. 2000;30:4-12.

Poch O, Blumberg BM, Bougueleret L, Tordo N. Sequence comparison of five polymerases ( $L$ proteins) of unsegmented negative-strand RNA viruses: theoretical assignment of functional domains. J Gen Virol. 1990;71:1153-1162.

Préhaud C, Harris RD, Fulop V, Koh CL, Wong J, Flamand A, Bishop DH. Expression, characterization, and purification of a phosphorylated rabies nucleoprotein synthesized in insect cells by baculovirus vectors. 1990;178(2):486497.

Rodero M, Jiménez A, Cuéllar C. Evaluation by ELISA of Anisakis simplex Larval antigen purified by affinity chromatography. Mem Inst Oswaldo Cruz. 2002;97(2):247252.

Rourou S, van der Ark A, van der Velden T, Kallel H. A microcarrier cell culture process for propagating rabies virus in Vero cells grown in a stirred bioreactor under fully animal component free conditions. Vaccine. 2007;25(19):3879-3889.

Rudd RJ, Smith JS, Yager PA, Orciari LA Trimarchi CV. A need for standardized rabies-virus diagnostic procedures: Effect of cover-glass mountant on the reliability of antigen detection by the fluorescent antibody test. Virus Res. 2005;111:83-88.

Rupprecht CE, Hanlon CA, Hemachuda T. Rabies re-examined. Lancet Infec Dis. 2002;2(6):327-343.

Schnell MJ, Conzelmann KK. Polymerase activity of in vitro mutated rabies virus L protein. Virology. 1995;214(2):522-530.

Schnell MJ, McGettigan JP, Wirblich C, Papaneri A. The cell biology of rabies vírus: using stealth to reach the brain. Nature. 2010;8:51-61.

Smith J, Yager PA, Baer GM. A rapid reproducible test for determining rabies neutralizing antibody. Bull World Health Organization. 1973;48:535-541. 
Sokol F, Stancek D, Koprowski H. Structural proteins of rabies virus. J Virol. 1973;7:241-249.

Swiss Institute of Bioinformatics - Expert Protein Analysis System, Viral Zone [homepage on internet]. Suiça: SIB. Disponível em: http://expasy.org/viralzone/all_by_protein/2.html. [2010 April].

Thraenhart O, Ramakrishnan K. Standardization of an enzyme immunoassay for the in vitro potency assay of inactivated tissue culture rabies vaccines: determination of the rabies virus glycoprotein with polyclonal antisera. J Biol Standard. 1989;17:291309.

Thomas JB, Sikes RK, Ricke AS. Evaluation of indirect fluorescent antibody technique for detection of rabies antibody in human sera. J Immunol. 1963;91:721723.

Thoulouze MI, Lafage M, Schachner M, Hartmann U, Cremer H, Lafon M. The neural cell adhesion molecule is a receptor for rabies virus. J Virol. 1998;72(9):7181-7190.

Tierkel ES, Atanasiu P. Rapid microscopic examination for Negri bodies and preparation of specimens for biological tests. In: Meslin FX, Kaplan MM, Koprowski $\mathrm{H}$. Laboratory techniques in rabies. 4th ed. Geneva: World Health Organization; 1996.55-65.

Tordo N, Poch O, Ermine A, Keith G, Rougeon F. Walking along the rabies genome: is the large G-L intergenic region a remnant gene? Proc Natl Acad Sci USA. 1986;83(11):3914-3918.

Tordo N, Poch O. Structure of rabies virus. In: Campbell JB, Charlton KM. Ed. Rabies. Boston: Kluwer Academic Publishers; 1988.25-45.

Tordo, N. Characteristics and molecular biology of the rabies virus. In: Meslin FX, Kaplan MM, Koprowiski H. Laboratory techniques in rabies. 4th ed. Geneva: World Health Organization; 1996.28-51.

Tordo N, Kouknetzoff $A$. The rabies virus genome: an overview. Onderst $\mathrm{J}$ Vet Res. 1993;60(4):263-269.

Tordo N, Poch O, Ermine A, Keith G, Rougeon F. Completion of the rabies virus genome sequence determination: highly conserved domains among the $L$ (polymerase) proteins of unsegmented negative-stand RNA-viruses. Virology. 1988;165:565-576.

Trimarchi CV, Rudd RD, Safford Jr M. An in vitro virus neutralization test for rabies antibody. In: Meslin FX, Kaplan MM, Koprowski H. Laboratory techniques in rabies. 4th ed. Geneva: World Health Organization; 1996.193-199.

Trimarchi CV, Smith JS. Diagnostic Evaluation. In: Jackson AC, Wunner WH. Ed. Rabies. Ed. Academic Press; 2002.308-349. 
Tsiang $\mathrm{H}$. Pathophysiology of rabies virus infection of the nervous system. Adv Virus Res. 1993;42:375-412.

Tuffereau C, Bénéjean J, Blondel D, Kieffer B, Flamand A. Low-affinity nervegrowth factor receptor (P75NTR) can serve as a receptor for rabies virus. EMBO J. 1998;17(24):7250-7259.

Warrell MJ, Warrell DAM. Rabies and other lyssavirus diseases. Lancet. 2004;363:959-969.

Webster LT, Dawson JL. Early diagnosis of rabies by mouse inoculation. Measurement of humoral immunity to rabies by mouse protection test. Proc. Soc. Exptl. Biol. Med. (NY). 1935;32:570-573.

Webster WA, Casey GA. Diagnosis of rabies infection. In: Campbell JB, Charlton KM. Rabies. Boston: Kluwer Academic Publishers; 1988.201-222.

Willoughby RE Jr, Tieves KS, Hoffman GM, Ghanayem NS, Amlie-Lefond CM, Schwabe MJ, Chusid MJ, Rupprecht CE. Survival after treatment of rabies with induction of coma. N Engl J Med. 2005,352(24):2508-2514.

World Health Organization. World survey of Rabies No. 34 for the Year 1998. Geneva:WHO; 2000.

World Health Organization. WHO Expert consultation on rabies. Geneva: WHO; 2005 (Séries Technical Report n. 931).

Wunner WH. Rabies virus. In: Jackson AC, Wunner WH. Ed. Rabies, 2nd ed. San Diego: Academic Press; 2007.23-68.

Wunner WH. Rabies Virus. In: Jackson AC, Wunner WH. Ed. Rabies. San Diego: Academic Press; 2002.23-77.

Wunner, WH, Dietzschold, B, Smith CL, Lafon, M, Golub, E. Antigenic variants of CVS rabies virus with altered glycosylation sites. Virology. 1985;140(1):1-12.

Zalan E; Wilson C; Pukitis D. A microtest for quantification of rabies virus neutralizing antibody. J Biol Stand. 1979;7:213-220. 


\section{ANEXO}

Soluções utilizadas

Tampão NT pH 7,5*

$\mathrm{NaCl}(0,13 \mathrm{M}) \quad 7,6 \mathrm{~g}$

TRIS $(0,05 \mathrm{M}) \quad 6,057 \mathrm{~g}$

Água destilada qsp $\quad 1000$ mL

${ }^{*}$ Ajustar pH para 7,5

Solução salina tamponada pH 7.0 - 0.01 M (PBS) 10x

$\mathrm{Na} 2 \mathrm{PO} 412 \mathrm{H} 2 \mathrm{O} \quad 26,5 \mathrm{~g}$

$\mathrm{NaH} 2 \mathrm{PO} 4 \mathrm{H} 2 \mathrm{O} \quad 3,6 \mathrm{~g}$

$\mathrm{NaCl} \quad 81,7 \mathrm{~g}$

Água destilada qsp $\quad 1000$ mL

Tampão hidroximetil - aminometano/cloreto de sódio (TED) pH 7.0*

Ácido acético, $1 \mathrm{~mol} / \mathrm{l} \quad 73 \mathrm{~mL}$

Água destilada $\quad 900 \mathrm{~mL}$

*ajustar o pH para 7.0 com etilenodiamina e então adicionar água destilada para $1000 \mathrm{ml}$

Ácido acético, $1 \mathrm{~mol} / \mathrm{l}$

Solução ácido acético, $17.3 \mathrm{~mol} / \mathrm{l} \quad 50 \mathrm{~mL}$

Água destilada $\quad 815 \mathrm{~mL}$

Solução saturada de sulfato de amônio pH 7.0

Sulfato de amônio $769,05 \mathrm{~g}$

Água destilada qsp $\quad 1000 \mathrm{~mL}$ 


\section{Reagente de Nessler*}

*Para cada $1 \mathrm{ml}$ de de amostra dialisada adiciona-se $50 \mu \mathrm{l}$ de reagente de Nessler. A ausência de precipitado de cor amarela no tampão indica que todo o Sulfato de Amônio foi retirado.

Tampão glicina $100 \mathrm{mM}, \mathrm{pH} 2.7^{*}$

Glicina $7,5 \mathrm{~g}$

Água destilada $q s p$ $1000 \mathrm{~mL}$

${ }^{*}$ Ajustar pH para 2.7

Tris $1 \mathrm{~mol} / \mathrm{L} \mathrm{pH} \mathrm{8,0}$

Tris $121,11 \mathrm{~g}$

Água destilada qsp $1000 \mathrm{~mL}$

${ }^{*}$ Ajustar pH para 8,0

ácido Tricloroacético 50\%

$\mathrm{HCl} 1 \mathrm{mM}^{*}$

*Adicionar $10 \mu \mathrm{L}$ de HCL em $120 \mathrm{~mL}$ de água destilada

Tampão de ligação $\mathrm{NaHCO}_{3} 0.1 \mathrm{~mol} / \mathrm{L}, \mathrm{pH} 8.3^{*}$, contendo $\mathrm{NaCl} 0.5 \mathrm{~mol} / \mathrm{L}$

$\mathrm{NaHCO}_{3} 0.1 \mathrm{~mol} / \mathrm{L}$ $2,1 \mathrm{~g}$

$\mathrm{NaCl} 0.5 \mathrm{~mol} / \mathrm{L}$ $7,3 \mathrm{~g}$

Água destilada $q s p$ $250 \mathrm{~mL}$

${ }^{*}$ Ajustar pH para 8.3

Tris-HCL $0.1 \mathrm{~mol} / \mathrm{L}, \mathrm{pH} 8.0^{*}$

Tris-HCL $12,0 \mathrm{~g}$

Água destilada qsp $1000 \mathrm{~mL}$

*Ajustar pH para $8.0 \mathrm{com} \mathrm{HCl}$ 
Tampão acetato $0.1 \mathrm{~mol} / \mathrm{L}, \mathrm{pH} 4.0^{\star}$ - contendo $\mathrm{NaCl} 0.5 \mathrm{~mol} / \mathrm{L}$

Acetato de sódio $0.1 \mathrm{~mol} / \mathrm{L} \quad 3,4 \mathrm{~g}$

$\mathrm{NaCl} 0.5 \mathrm{~mol} / \mathrm{L} \quad 7,3 \mathrm{~g}$

Água destilada qsp $\quad 250 \mathrm{~mL}$

${ }^{*}$ Ajustar pH para 4.0

Tampão Tris-HCl $0.1 \mathrm{~mol} / \mathrm{L}, \mathrm{pH} 8.0^{\star}$ - contendo $\mathrm{NaCl} 0.5 \mathrm{~mol} / \mathrm{L}$

Tris-HCL

$3,0 \mathrm{~g}$

$\mathrm{NaCl} 0.5 \mathrm{~mol} / \mathrm{L}$

$7,3 \mathrm{~g}$

Água destilada qsp

$250 \mathrm{~mL}$

*Ajustar pH para $8.0 \mathrm{com} \mathrm{HCl}$ 